Aus der Abteilung Neurophysiologie und Sinnesphysiologie

(Prof. Dr. med. D.W. Richter)

im Zentrum Physiologie und Pathophysiologie

der Medizinischen Fakultät der Universität Göttingen

\title{
Influence of GPCR coexpression in neuronal cells on the convergence of signaling pathways
}

\author{
INAUGURAL-DISSERTATION \\ zur Erlangung des Doktorgrades \\ der Medizinischen Fakultät \\ der Georg-August-Universität zu Göttingen
}

vorgelegt von

Tim Ullrich

aus Braunschweig

Göttingen 2013 
Dekan: Prof. Dr. rer. nat. Heyo K. Kroemer

I. Berichterstatter: Prof. Dr. med. D.W. Richter

II. Berichterstatter: Dr. med. Nikolaev

Tag der mündlichen Prüfung: 29.07.2013 


\section{Contents}

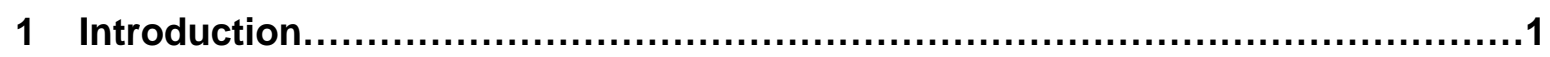

1.1 The role of serotonin in long and short distance communication between cells........1

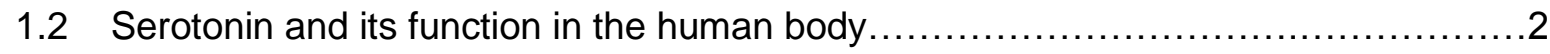

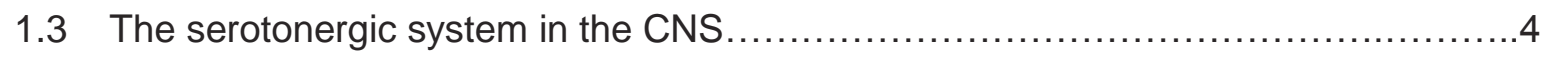

1.4 Serotonin receptors and signaling cascades on molecular level...................6

1.4.1 General structure and mechanism of GPCRs $\ldots \ldots \ldots \ldots \ldots \ldots \ldots \ldots \ldots \ldots \ldots$

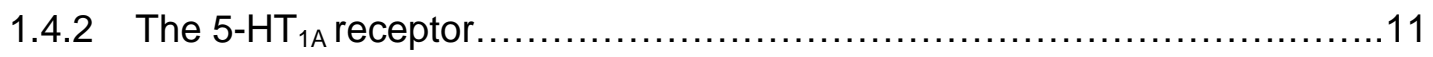

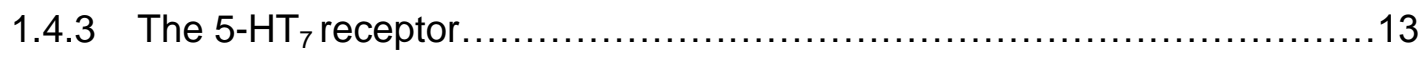

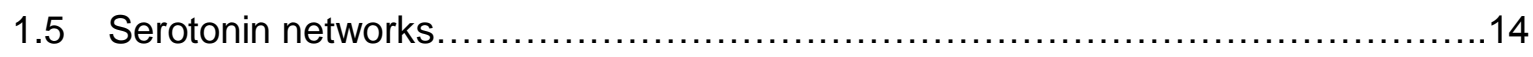

1.5.1 Promiscuity in $5-\mathrm{HT}$ signaling pathways................................

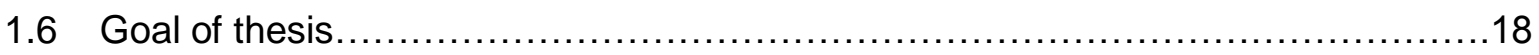

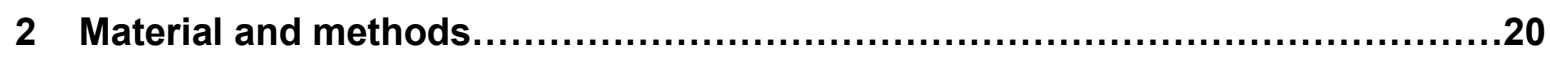

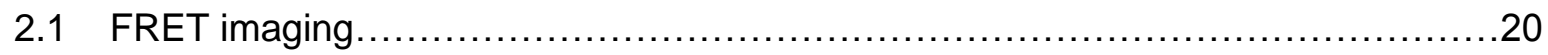

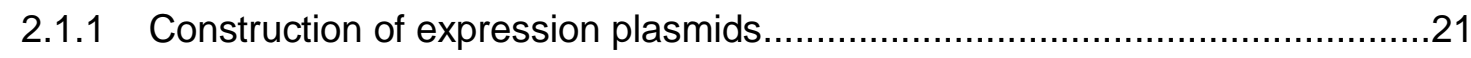

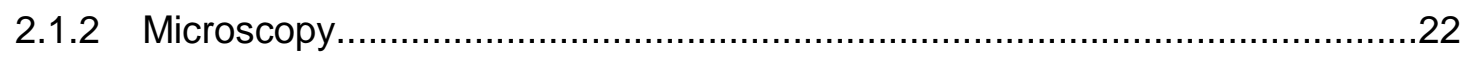

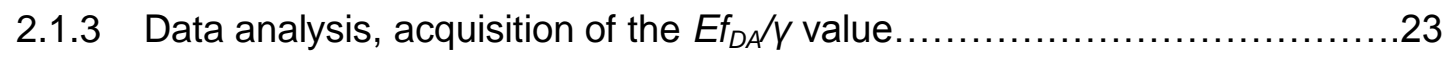

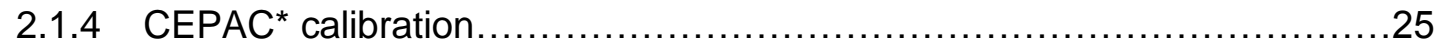

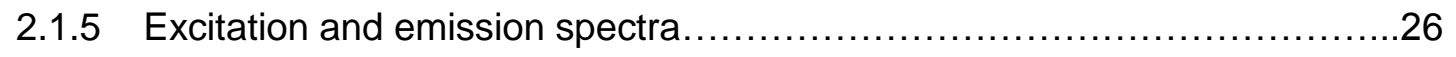

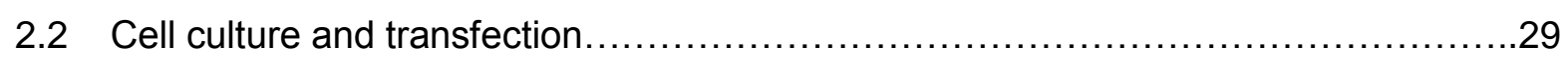

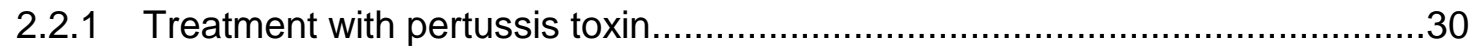

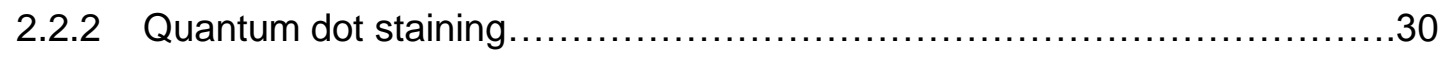


2.3 Solutions, agonists and antagonists.

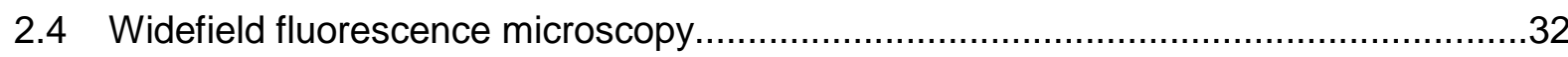

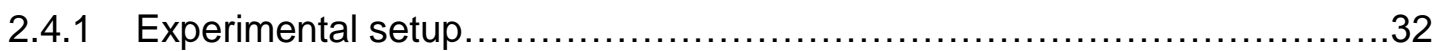

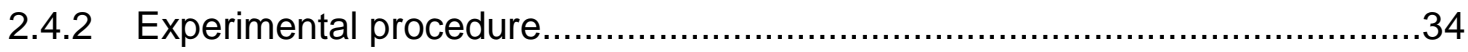

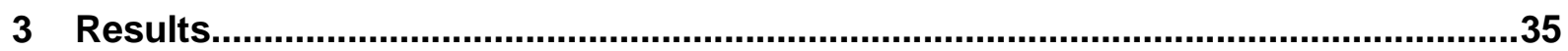

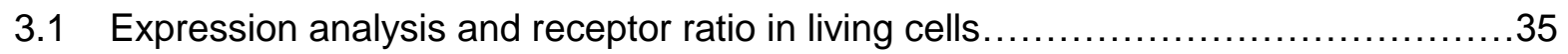

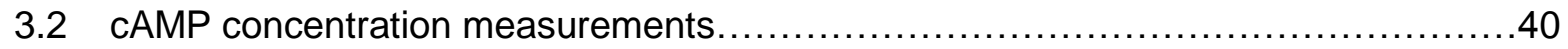

3.2.1 Kinetic measurements, comparison of stimulation - response intervals........42

3.2.2 5- $\mathrm{HT}$ activation of $5-\mathrm{HT}_{7}$ and $5-\mathrm{HT}_{1 \mathrm{~A}}$ coexpressing cells....................44

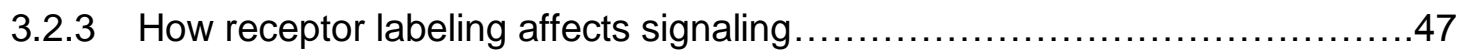

3.2.4 Functional interaction between $5-\mathrm{HT}_{1 \mathrm{~A}}$ and $5-\mathrm{HT}_{7}$ receptors.................48

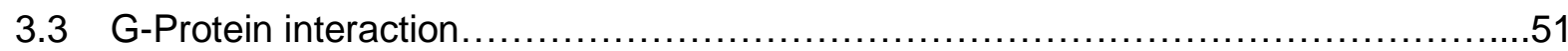

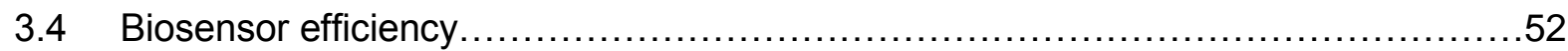

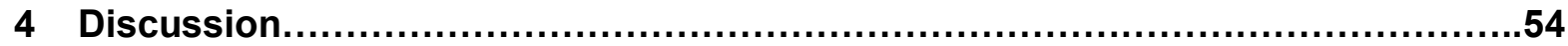

4.1 Receptor crosstalk - coexpression generates novel functionality $\ldots \ldots \ldots \ldots \ldots \ldots \ldots \ldots \ldots 4$

4.1.1 Oligomerization, coactivation and trans-inhibition.............................

4.1.2 Effect of coexpression on receptor pharmacology - altered agonist- and

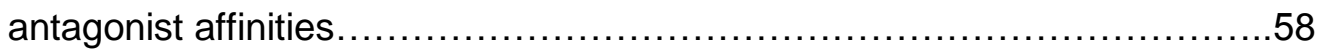

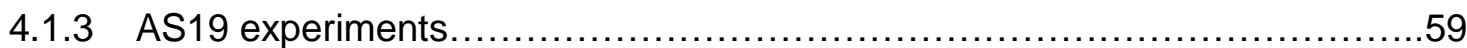

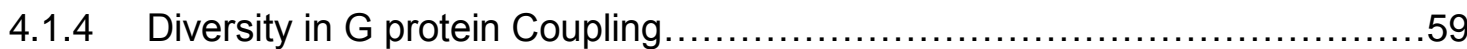

4.2 Coexpression analysis, receptor distribution and fluorescence labeling ...............62

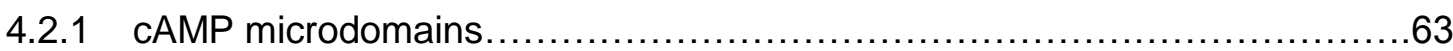


4.3 Signal transmission and crosstalk by $\mathrm{G}$ protein- $\beta y$ subunits.........................64

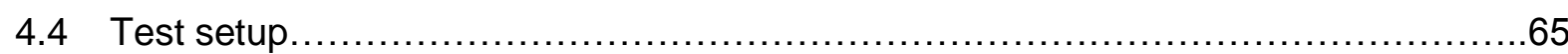

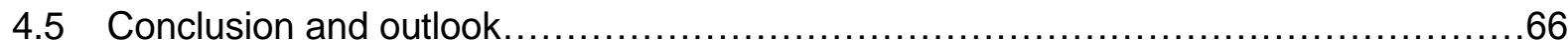

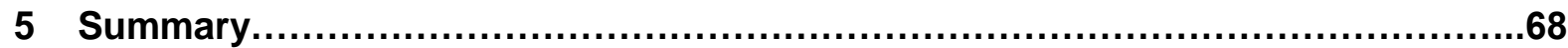

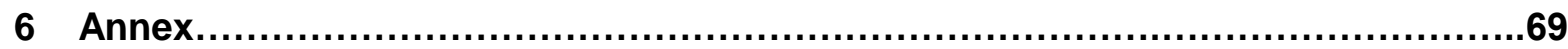

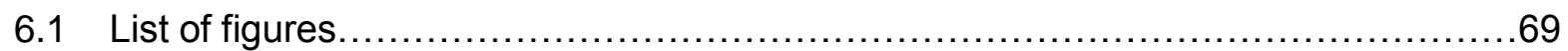

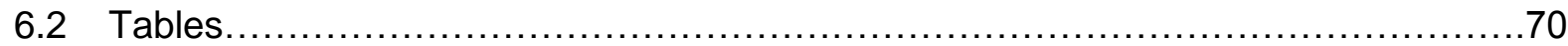

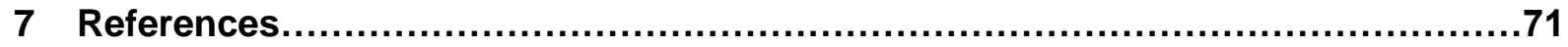


Introduction

\section{Introduction}

\subsection{The role of serotonin in long and short distance communication between cells}

For every properly functioning organism it is essential that its different organs as well as its single cells communicate and coordinate their functions.

Communication between body organs or cells is not to be understood as conscious message transmission. Adjacent cells or cells of a remote organ react on stimuli from other cells in a predefined, distinct manner. These stimuli can be electrical in nature, chemical or mechanic. Organs can, on the one hand, react on a current biological condition of the organism that was caused by other organs in the first place. In case of this indirect "communication" an organ perceives the extent of a particular physiological parameter and responds with an appropriate adjustment of its cell functions. Accordingly, arterial baroreceptors in the human aortic arch for example recognize blood pressure changes as result of adrenaline rush during strong excitement and induce alteration of the force and speed of the heart's contractions through the central nervous system. On the other hand, there are direct communication systems, which utilize messenger substances for directed transport of information. Thus, cells of particular organs can be informed about the activity- and metabolic state of the whole organism, the microenvironment and the need to activate, up- or downregeulate certain of their cell functions. This thesis discusses one of the most important and widespread messenger systems in mammals and two of its cellular receptors in particular: the serotonergic system with its receptors $5-\mathrm{HT}_{1 \mathrm{~A}}$ and $5-\mathrm{HT}_{7}$. Messenger substances are generally released by cells or glands in one part of the organism and convey their message to cells in other parts. This sort of long distance communication is termed endocrine signaling. Thereby, a particular messenger molecule affects only these cells, which express a certain receptor that is capable to receive and transmit the incoming signal. A messenger released from some part of the body can therefore directly control a single cells individual biological activity within the context of the organism as whole. Not only cells from different organs communicate with each other but also adjacent cells within one functional region can influence each other through messengers. Communication between cells via direct contact is called juxtacrine signaling while signaling over short distances is named paracrine. The messenger substances used for cellular signaling have been functionally classified as: hormones, growths factors, extra-cellular matrix components, cytokines, chemokines, neurotransmitters, neurotrophins and active oxygen species. Serotonin is one representative of these messenger molecules that performs paracrine signaling as neurotransmitter as well 
as endocrine signaling as hormone in the human body. Both ontogenetically and phylogenetically the serotonergic system is one of the first neurotransmittersystems to manifest in mammalian central nervous systems (CNS) (Kriegebaum et al. 2010 a).

The CNS is the anatomic correlate of the complex information processing network that enables the human body to accomplish and regulate autonomic vital processes as well as complicated cognition-, thinking- and movement processes. It contains the brain, spinal cord and retina and integrates the information that it receives from, and coordinates the activity of the peripheral nervous system (PNS). The PNS conducts collected information from the periphery via sensory (afferent) pathways to the CNS. The latter processes the gathered information and induces movements via motoric (efferent) pathways and nerves. The basis of CNS information processing is formed by nerve cells, neurons that connect to each other through synaptic interfaces to form networks. Receptors on the postsynaptic side receive information from presynaptic neurons or from adjacent glia cells. Receptors of a neuron are particular protein molecules to which one or more specific kinds of messenger substance, generally neurotransmitters may attach. Binding of these ligands then leads to a change and/or stabilization of a certain shape, the conformation of the receptor. Subsequently, this conformational change may trigger some sort of cellular response e.g. opening or closing of ion channels or initiation of an intracellular signaling cascade using second messenger molecules. Hence, cells can communicate over long distances or with cells in the vicinity via messengers, in this case either hormones or neurotransmitters which bind to the appropriate receptor of another cell. As mentioned above the serotonergic system with its multifunctional messenger serotonin is one of the most important messenger systems and controls numerous core functions of the human body.

\subsection{Serotonin and its function in the human body}

This thesis is meant to further clarify the role and interaction of the two serotonin receptors 5$\mathrm{HT}_{1 \mathrm{~A}}$ and $5-\mathrm{HT}_{7}$ within the complex serotonergic network.

Serotonin, or 5-Hydroxytryptamine $(5-\mathrm{HT})$, is a widely spread messenger substance in nature. Even single-celled organisms like entamoeba histolytica are reported to produce serotonin and use its features as an essential trigger of diarrhea in humans, seen in amebiasis (McGowan et al. 1983). Also plants are to count among the group of serotonin producing organisms. Thus serotonin in stinging nettles is jointly responsible for their known effect. Based on the fact that serotonin and its receptors already occur in such simple species as the nematode (roundworm) Caenorhabditis elegans it is believed that 
Introduction

serotonergic systems evolved in the cryptozoic eon about $700-800$ million years ago (Peroutka and Howell 1994).

As Indolamine, 5-HT belongs like the three ketecholamines adrenaline (epinephrin), noradrenaline and dopamine as well as the neurotransmitter histamine to the group of monoamine neurotransmitters. Maurice Rapport was the first one to reveal its chemical structure in 1949 (Rapport 1949). Chemically it is based on an indole structure containing an amino group and a substituted hydroxyl group. (Fig. 1.1)

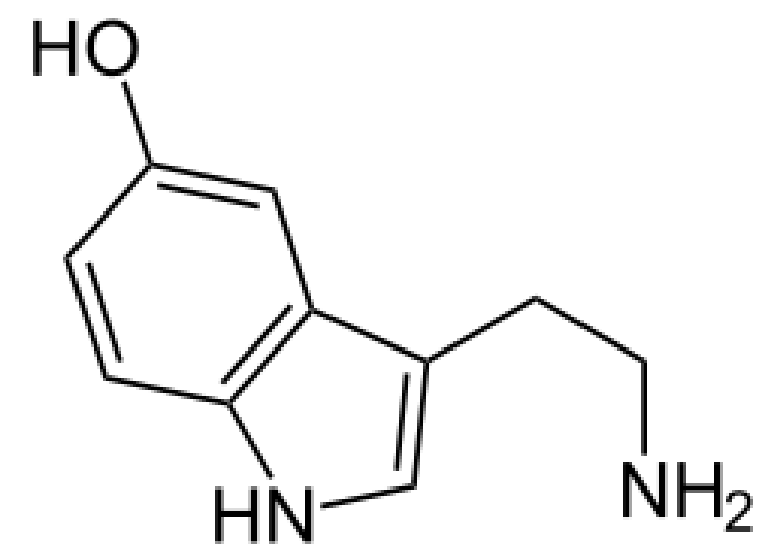

Fig.1.1 structural formula of serotonin

Modified according to Amit et al. (1978, P. 268) The figure shows the chemical structure of serotonin according to x-ray crystallographic determination; Molecular formula: $\mathrm{C}_{10} \mathrm{H}_{12} \mathrm{~N}_{2} \mathrm{O}$.

In human metabolism, 5-HT is derived from the amino acid L-tryptophan by a short metabolic pathway consisting of two enzymes: tryptophan hydroxylase (TPH) and amino acid decarboxylase (DDC). (Fig. 1.3) In the body approximately $90 \%$ of the total serotonin amount, valued at $10 \mathrm{mg}$, is located in the enterochromaffin cells in the digestive tract. The remainder is found in neurons of the digestive nervous system and the CNS or in blood circulation. The name serotonin was derived from its presence in the blood serum where it regulates the tone of the bloodvessels. This function already constitutes an important effect on human homeostasis. As early as in the 1930s Vittorio Erspamer revealed that an extract from the enterochromaffin cells, which he named "enteramine", made smooth muscle cells in the intestine contract. Over the years it became apparent that $5-\mathrm{HT}$ is involved in a tremendous diversity of functions: regulation of the cardiovascular system and the blood pressure, (Hoyer et al. 1994) blood clotting, peristalsis of the digestive tract (Gershon 1999) and intraocular pressure modification (Costagliola et al. 2008).

The impact of $5-\mathrm{HT}$ in the CNS affects almost every brain function like cognition and memory, circadian rhythm, (Duncan et al. 1999, Lovenberg et al. 1993) temperature 
Introduction

regulation (Balcells-Olivero et al. 1998, Gilbert et al. 1988, Hjorth 1985, Seletti et al. 1995) sensors and pain perception, appetite, sexual behavior and hormone secretion to mention the most important aspects. Its influence on mood gave him the nickname happiness hormone.

\subsection{The serotonergic system in the CNS}

Investigation of the serotonergic network generally affects every cell system in the body that makes use of sorotonergic signal transduction. The purpose of this thesis might be particularly interesting for serotonin processes in the hippocampus, as hippocampal neurons have been found to coexpress the very two subtypes of serotonin receptors this investigation is dealing with: 5- $\mathrm{HT}_{1 \mathrm{~A}}$ and 5- $\mathrm{HT}_{7}$ (Bickmeyer et al. 2002, Neumaier et al. 2001, Azmitia et al. 1996). It is also interesting that the respective expression levels of $5-H T_{1 A}$ and $5-H T_{7}$ in the hippocampus vary during development (Renner et al. 2012) and therefore interaction of the two receptors might be tuned differentially at distinct stages.

Serotonergic neurons are mainly located in groups (raphe nuclei) paramedian of the brain stem. Raphe means "seam" and refers to the midline of the brain stem. These raphe complexes can be devided into two subgroups as related to their projection field. Raphe serotonergic neurons of the caudal brain stem, such as raphe magnus, raphe pallidus and raphe obscurus and parts of the adjacent lateral reticular formation form descending tracts and project prominently to the motoric and autonomous systems of the spinal cord. Fibers of raphe obscurus and pallidus exert an activating affect on anterior horn motor neurons of flexor and extensor muscle groups in the medulla. Serotonergic axons of raphe magnus terminate in the dorsal horn of the medulla. Here, released serotonin activates enkephalinergic interneurons which inhibit transmission of nociceptive stimuli (pain sensation) (Kriegebaum et al. 2010 a, Gulbins and Lang 2011). Nuclei of the rostral raphe complex are raphe pontis, raphe dorsalis, raphe medianus, raphe linearis caudalis and the nucleus tegmenti retikularis pontis. They principally project to the diencephalon and forebrain and terminate in neuron complex areas such as amygdala, cerebral cortex, striatum and hippocampus (Kriegebaum et al. 2010 a, Gulbins and Lang 2011). These structures constitute the anatomic correlates of complex neuronal networks that control many neural functions through integrated circuitry between each other. Serotonergic fibers are one part of this neuronal matrix and therefore involved in control of the core functions mentioned above, such as cognition and memory, circadian rhythm, temperature regulation, appetite, sexual behavior and mood. 
Analysis of the interaction of the two $5-\mathrm{HT}$ receptor subtypes $5-\mathrm{HT}_{1 \mathrm{~A}}$ and $5-\mathrm{HT}_{7}$ might be of special relevance to hippocampal neurons, which have been shown to coexpress these receptor subtypes. The hippocampus is a major brain structure in the temporal lobe of the cerebral cortex and is made up of three subunits, namely Ammon's horn (hippocampus proper), dentate gyrus and subiculum. The hippocampal formation stretches from the amygdala to the splenium of the corpus callosum and is laterally limited by the inferior horn of the lateral ventricle (Kleine and Rossmanith 2009). Functionally, the hippocampus is responsible for the transfer of declarative memory from short-term to long-term memory. In this regard the hippocampus is traditionally widespread mentioned as part of the Papez circuit, an early concept of the memory storing system. Later the hippocampus was considered to be a part of the limbic system, a likewise obsolete concept of brain structures with a particular set of functions. The hippocampus also plays an important role in spatial orientation and in emotion. Thus depression seems to reduce the hippocampal volume (Campbell and Macqueen 2004). It receives input from different sensory systems, which gets processed and send back to the cortex. (Fig.1.2) The major input unit of the hippocampal formation is the entorhinal cortex, which is assigned to the parahippocampal regions. It obtains sensory and motor information from several areas of temporal, frontal, olfactory and midline cortices, amygdala, claustrum, thalamus and the mammillary complex. Other input originates from the medial septal nucleus via fornix (Casas and Tranel 2008). The focus, considering the actual thesis, is on serotonergic input from raphe nuclei besides other brainstem nuclei input as e.g. noradrenergic fibers from locus coeruleus. The entorhinal cortex subsequently conveys the information to the dentate gyrus which forwards it to hippocampus proper. Several feedback loops and local projections of interneurons modify the information flow in the hippocampal formation. The subiculum constitutes the major output entity of the formation. It sends information to cingulate, retrosplenial and frontal cortex areas as well as to thalamic nuclei, hypothalamic nuclei, amygdala and the mammillary complex (Casas and Tranel 2008). 


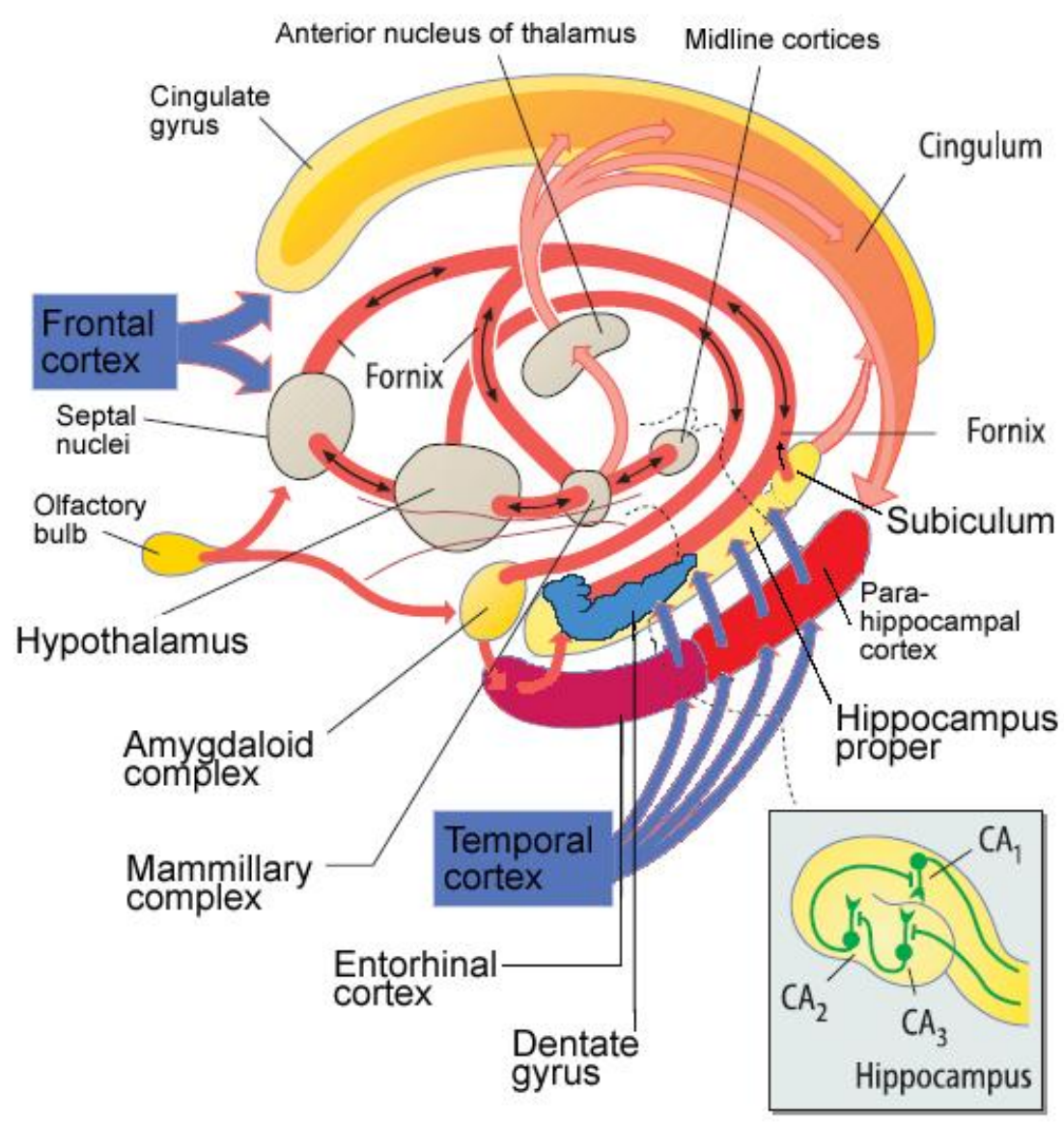

Fig. 1.2 Hippocampal signaling

Modified according to Lang and Lang (2007, P. 449) The scheme illustrates the circuitry between the different neuronal domains in the brain involved in learning and formation of memory in relation to the hippocampus.

The serotonergic fibers terminating in the hippocampus are among other things believed to affect the learning process as well as emotional regulation and anxiety (Kriegebaum et al. 2010 b). Accordingly, the serotonergic system is regarded as the focus of current hypotheses on the pathogenesis of disorders with the shared feature of emotional dysregulation.

\subsection{Serotonin receptors and signaling cascades on molecular level}

Serotonin functions via at least 14 different classes of serotonin receptors also known as 5$\mathrm{HT}$ receptors (5-HTR). The purpose of the actual thesis is to examine the interaction between the serotonin receptor subtypes $5-\mathrm{HT}_{1 \mathrm{~A}}$ and $5-\mathrm{HT}_{7}$ and their mutual impact on cellular signal transduction. For the serotonergic network is far more than just the sum of its individual receptor-pathways. Interference and signal modulation occur on many levels. 
Except the 5- $\mathrm{HT}_{3}$ receptor group which gate a cation-permeable ion channel, all 5-HT receptors are G protein coupled receptors (GPCRs). GPCRs constitute one particular cellular transmission mechanism which will be explained in detail in the following chapter. In order to classify the 5-HT receptors in a more systematic manner they can be divided in 7 receptor families termed $5-\mathrm{HT}_{1}$ up to $5-\mathrm{HT}_{7}$. These families can be subdivided into diverse subtypes which together make up the 14 different receptors. Each receptor can be attributed a particular set of preferential ligands, main localization and major pathways as well as physiological impact.

"Although there are no absolute distinctions between 5-HT receptors in their signaling modes, and no individual subtype possesses just one single transduction mechanism", (Millan et al. 2008, P. IV) there are certain general tendencies regarding the function of the different receptors, which are worth mentioning (Fig. 1.3). The 5- $\mathrm{HT}_{1}$ receptor family represents with its subtypes $5-\mathrm{HT}_{1 \mathrm{~A}}, 5-\mathrm{HT}_{1 \mathrm{~B}}, 5-\mathrm{HT} \mathrm{T}_{1 \mathrm{D}}, 5-\mathrm{HT}_{1 \mathrm{e}}$ and $5-\mathrm{HT}_{1 \mathrm{~F}}$ the biggest subgroup of serotonin receptors. These receptors collectively inhibit the creation of the cellular second messenger cyclic adenosine monophosphate (cAMP) via $G_{i / o}$ proteins. The enzyme adenylyl cyclase (AC) converts adenosine triphosphate to cAMP under the control of either stimulating $\left(G_{s}\right)$ or inhibiting $\left(G_{i / 0}\right) G$ proteins. (see below) cAMP in turn stimulates the cAMP-dependent protein kinase $A(P K A)$ which downstream can phosphorylate manifold effector proteins. Moreover CAMP has been shown to activate the family of GTPase exchange factors Epac ${ }_{1-2}$ (exchange protein directly activated by CAMP) (De Rooij et al. 1998) that subsequently activate small Ras-like GTPase proteins, such as Rap1 or Rap2. Functionally, cAMP signaling mediates diverse cellular responses throughout the body involved in the regulation of processes such as cardiac contraction, insulin secretion and neurotransmitter release in neurons, many of which are found to be modulated via both pathways PKA- and Epacmediated (Gloerich and Bos 2010).

The $5-\mathrm{HT}_{2}$ triplets $(\mathrm{A}, \mathrm{B}$ and $\mathrm{C})$ share recruitment of phospholipase $\mathrm{c}$ via $\mathrm{G}_{\mathrm{q} / 11}$ as their primary mode of signaling. 5- $\mathrm{HT}_{2 \mathrm{~A}}$ receptors play an important role in blood clotting in thrombocytes. $5-\mathrm{HT}_{2 \mathrm{~B}}$ receptors are reported to be associated with diseases like migraine and chronic hypertension whereas $5-\mathrm{HT}_{2 \mathrm{C}}$ receptors are shown to be linked with regulation of eating- and sexual behavior in the CNS. The $\mathrm{K}^{+}$and $\mathrm{Na}^{+}$selective ion channel $5-\mathrm{HT}_{3}$ is revealed to be a highly effective target for antagonists to suppress cytostatics induced vomiting. The receptor families $5-\mathrm{HT}_{4}, 5-\mathrm{HT}_{6}, 5-\mathrm{HT}_{7}$ all stimulate $\mathrm{AC}$ via $\mathrm{G}_{\mathrm{s}} \mathrm{G}$ proteins. The two $5-\mathrm{HT}_{5}$ subgroups $\mathrm{A}$ and $B$ both inhibit $A C$ likely via $G_{i / o}$ (Nelson 2004). 


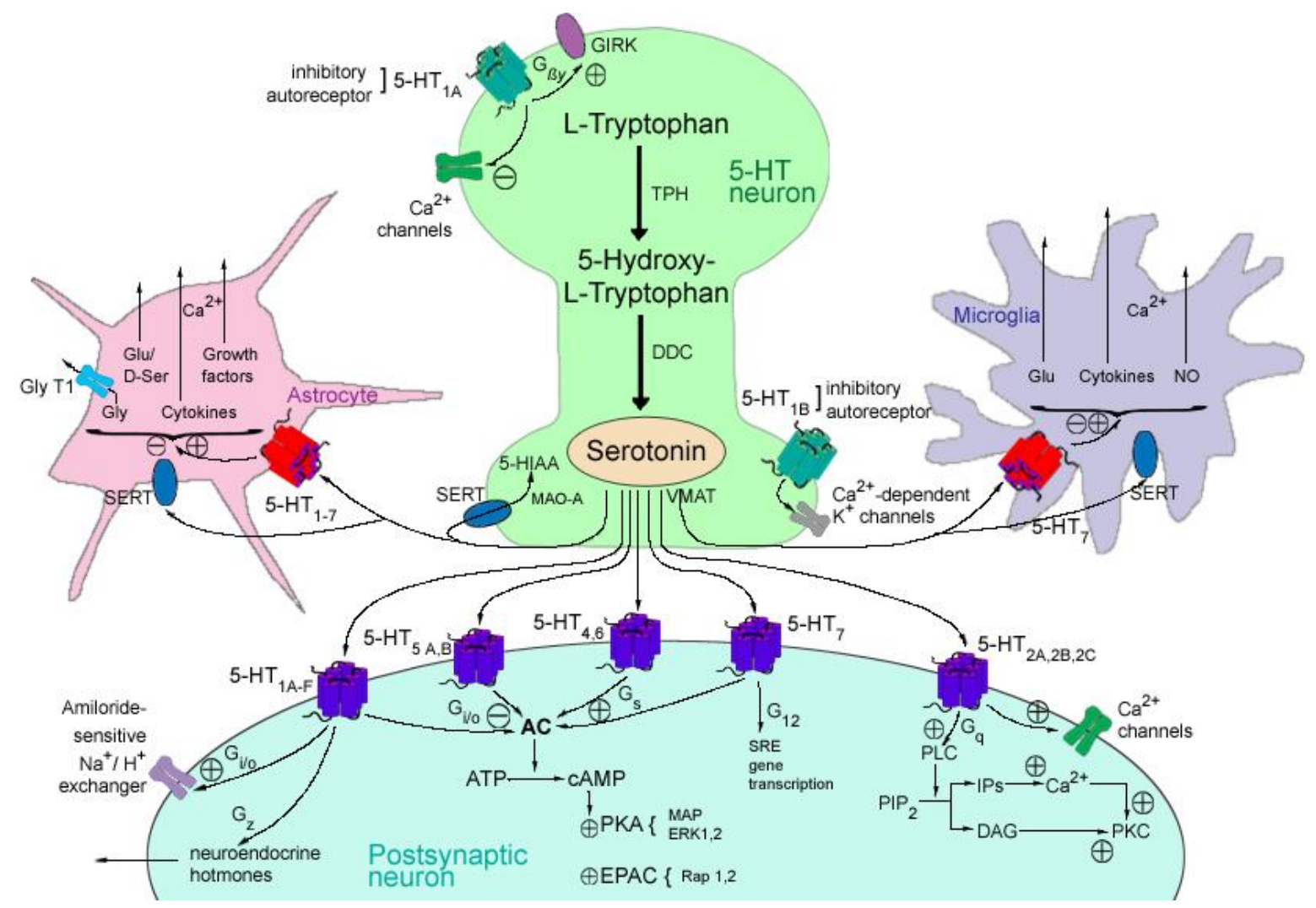

Fig. 1.3 Principal serotonergic signaling cascades

Modified according to Millan et al. (2008, P. 455). The figure depicts the biosynthesis of serotonin in neuronal cells in two enzymatic steps and its deactivation by monoamine oxidase A (MAO-A) after release and reuptake through serotonin transporters (SERT). Moreover the main targets of serotonin are displayed and also the downstream signaling cascades with the involved messengers in adjacent cells. 5-HT inhibitory autoreceptors are localized presynaptically. 5-HT receptor activation in nonneuronal cells can lead to release of further modulators. The scheme does not claim any completeness. Abbreviations: 5-HIAA, 5-hydroxyindole amino acid; DAG, diacylglycerol; DDC, amino acid decarboxylase; D-Ser, D-serine; EPAC, exchange protein directly activated by CAMP; ERK 1,2, extracellular signal regulated kinases; GIRK, G protein coupled inward rectifier potassium channel; Glu, glucose; Gly, glycine; GlyT1, glycine transporter; IP, inositol phosphate; MAP, mitogen activated protein kinases; NO, nitric oxide; $\mathrm{PIP}_{2}$, phosphoinositol bisphosphate; PKA, protein kinase A; PKC, protein kinase c; PLC, phospholipase c; Rap1,2, small Ras-like GTPase proteins; SRE, serum response element; TPH, tryptophan hydroxylase; VMAT, vesicular monoamine transporter

\subsubsection{General structure and mechanism of GPCRs}

The understanding of the basic structure and modes of action of the receptors examined is required for developing hypotheses about their interaction.

Except the $5-\mathrm{HT}_{3}$ receptor all 5-HT receptors belong to the family of $\mathrm{G}$ protein-coupled receptors. Based on homology in sequence and mode of function GPCRs can be subdivided 
in 6 classes A (Rhodopsin-like), B (Secretin receptor family), C (Metabotropic glutamate/pheromon), D (Fungal mating pheromone receptors), E (Cyclic AMP receptors) and $F$ (Frizzled/Smoothened) (Attwood and Findlay 1994). 5-HT receptors belong to class $A$ which is by far the largest. In general, GPCRs are composed of a single-polypeptide chain that has seven membrane-spanning domains with three intracellular and three extracellular loops of amino acids (Fig.1.4). The amino- terminal end of the protein is extracellular and the carboxyl- terminal end is located in the cytoplasm. Often extracellular loop two covers the cavity formed by the remaining helices, serving as a modulator for ligands to attach to the binding domain (Cherezov et al. 2007). Intracellular loop three constitutes the binding- and activation-domain for signaling molecules like $G$ proteins and therefore has a determining influence on receptor-G protein specificity (Rosenbaum et al. 2007).

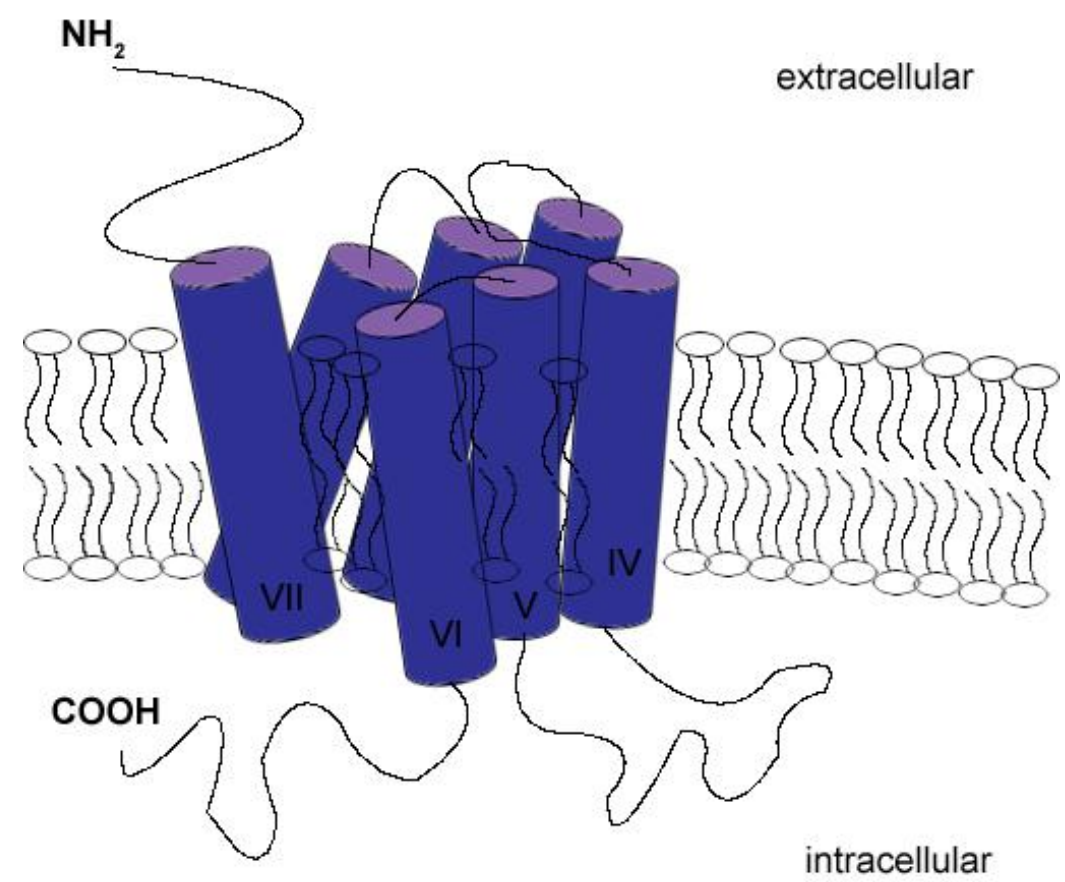

\section{Fig. 1.4 Morphology of G protein-coupled receptors}

Schematic illustration of GPCRs showing the seven hydrophobic membrane-spanning domains (numbered I-VII) with three intracellular and three extracellular loops of amino acids. The aminoterminal end $\left(\mathrm{NH}_{2}\right)$ is located extracellular while the carboxyl-end $(\mathrm{COOH})$ is intracellular. Extracellular loop two spans the receptor cavity and intracellular loop three is responsible for $G$ protein binding.

Basically, upon ligand binding GPCRs undergo a conformational shift which results in the activation of the associated $G$ protein that represents the transduction element between the receptor and the second messenger system. 
The conformational change leads to a rearrangement of the transmembrane domains of the GPCR, thereby passing different energetic levels. These changes are not understood in detail so far. Several scenarios are conceivable. Upon binding agonists might disrupt intramolecular interactions that stabilize the inactive state of the receptor or agonists could stabilize a more active state by serving as bridges that create new interactions between transmembrane domains (Kobilka and Deupi 2007). Discussing the different energetic states and functional states, respectively, of GPCRs, it is necessary to clarify the nature of these distinct modes. GPCRs in general, except the light absorbing rhodopsin, have more than two activity levels. GPCRs possess a whole continuum of various functional activity states reaching from no activity to maximum activity. Different ligands may favor distinct conformational states which in turn determine different functional states (Kobilka and Deupi 2007). Many GPCRs have a certain agonist independent basal activity. Pure "agonists" fully activate the receptor by definition, whereas "partial agonists" induce submaximal activation. "Inverse agonists" suppress basal activity. The activated receptor subsequently causes a conformational change of the attached $G$ protein, resulting in the exchange of the $G$ protein bound guanosine diphosphate (GDP) with guanosine triphosphate (GTP). The heterotrimeric $G$ protein then dissociates from the GPCR and splits up into the active GTP bound $G_{\alpha}$ subunit and the $G_{\beta y}$ dimer. These subunits activate primary effectors which modulate ion or second messenger concentrations as for example cAMP generated by AC. $G_{a}$ subunit activity is terminated by hydrolyzation from GTP to GDP and $G_{\alpha}$ can reassociate with a $G_{\beta y}$ unit to enter a new signaling cycle. Thus, the system allows for a high degree of amplification of the signal. There are different types of $G_{\alpha}$ subunits such as $G_{s} \alpha$ ( $G$ stimulatory), $G_{i} \alpha$ ( $G$ inhibitory), $G_{0} \alpha$ ( $G$ other), $G_{q / 11} \alpha$, and $G_{12 / 13} \alpha$. Traditionally, the $G_{\beta \gamma}$ unit was sparsely noted and seen as a passive, inhibiting modulator of $G_{\alpha}$ subunits effectors. Nowadays it is known that the $G_{\beta \gamma}$ subunit impacts on various effectors such as $A C$ (see below), phospholipase $C$, (Nielsen et al 1991, Camps et al. 1992) phospholipase A2, phosphoinositide 3-kinase (Stephens et al. 1994), G protein coupled inward rectifier potassium (GIRK) channels (Logothetis et al. 1987) and the beta-adrenergic receptor kinase (Krapivinsky et al. 1995). Besides multifaceted mutual crosstalk and G protein unselectivity (discussed below), diverse post-translational modifications constitute a common way of receptor regulation. GPCRs possess multiple intracellular sites susceptible to phosphorylation. Different enzymes like PKA, PKC or GPCR kinases (GRK) are able to attach negatively charged phosphor to the receptor, leading to conformational change and consequently attenuated signaling due to blunted G protein coupling (Tobin 2008). Furthermore, phosphorylation can trigger $\beta$-arrestin binding to the receptor. $\beta$-arrestins serve as scaffolds for many proteins as clathrin or MAP kinases. Subsequently the receptor can be internalized trough clathrin-mediated endocytosis 
in the fashion of receptor down regulation in order to allow desensitization after prolonged receptor stimulation. Interestingly, $\mathrm{G}_{\alpha}$ protein subunits can also be phosphorylated, further tempering signal transduction (Hensler 2003). Another important modification is receptor glycolisation. $\mathrm{N}$-asparagine glycolisation for example is required for $5-\mathrm{HT}_{1 \mathrm{~A}}$ plasma membrane expression (Dutton et al. 2008).

Moreover the covalent attachement of palmitic acid to the C-terminus of GPCRs represents a common receptor modification, impacting receptor function, trafficking and especially receptor accumulation in lipid rafts as it is required for efficient signaling (Resh 2006). Collaborating groups have shown that $5-\mathrm{HT}_{1 \mathrm{~A}}$ receptors are stably palmitoylated and palmitoylation is necessary for $5-\mathrm{HT}_{1 \mathrm{~A}}$ G protein coupling (Kobe et al. 2008).

\subsubsection{The $5-\mathrm{HT}_{1 \mathrm{~A}}$ receptor}

The $5-\mathrm{HT}_{1 \mathrm{~A}}$ receptor is the most widespread of the serotonin receptors. Its countercooperative impact on cellular cAMP makes it an interesting object of investigation in combination with its opponent, the $5-\mathrm{HT}_{7}$ receptor. Besides serotonin $5-\mathrm{HT}_{1 \mathrm{~A}}$ receptors can be activated by 5 carboxamidotryptamine (5-CT) (Yamada et al. 1998). It is expressed in the cerebral cortex, hippocampus, raphe nuclei, septum, and throughout the brainstem, to mention the main loci (Azmitia et al. 1996, Kia et al. 1996). Most of the 5-HT $\mathrm{HA}_{\mathrm{A}}$ receptors in the raphe nuclei are somatodendritic autoreceptors being involved in receptor signaling via negative feedback cycles. In other regions such as the hippocampus, the $5-\mathrm{HT}_{1 \mathrm{~A}}$ receptor is located postsynaptically. Functionally, the $5-\mathrm{HT}_{1 \mathrm{~A}}$ receptor affects a huge number of physiological phenomena; partially neuro-endocrine functions and partially peripheral effects. The receptor is involved in thermoregulation (Balcells-Olivero et al. 1998, Gilbert et al. 1988, Hjorth 1985, Seletti et al. 1995) and central down-regulation of blood pressure and heart rate. Receptor activation in rostral ventrolateral medulla neurons trigger peripheral vasodilation contributing to pressure regulation and body temperature via heat dissipation (Dabiré 1991). $5-\mathrm{HT}_{1 \mathrm{~A}}$ activation has been reported to affect immune function by elevating B-lymphocyte proliferation (Iken et al. 1995). Moreover, the $5-\mathrm{HT}_{1 \mathrm{~A}}$ receptor is strongly associated with memory and cognition whereby receptor agonists have generally been shown to impair learning by interfering with memory-encoding mechanisms (Edagawa et al. 1998, Ogren et al. 2008). Apart from that, $5-\mathrm{HT}_{1 \mathrm{~A}}$ activation has been revealed to reduce aggressive behavior (Miczek et al. 1998). Neuro-endocrinologically, $5-\mathrm{HT}_{1 \mathrm{~A}}$ activation triggers secretion of manifold hormones like cortisol, corticosterone, adrenocorticotropic hormone (ACTH), oxytocin, prolactin, growth hormone, and $\beta$-endorphin (Van de Kar et al. 1998, Koenig et al. 1987). 
An important role in pathologic states and disorders like depression, schizophrenia, anxiety, (Toth 2003) Alzheimer's Disease and also ischemic stroke, (Kamei et al. 2001) is attributed to $5-\mathrm{HT}_{1 \mathrm{~A}}$ dysfunction which is reflected in the huge amount of medications targeting this receptor. Most drugs are aimed at increasing the general serotonin level in the synaptic cleft which has been shown to be a major effect in the treatment of depression. This can be achieved by supplementation of serotonin precursors like L-tryptophan and 5-HTP, serotonin reuptake inhibition by selective serotonin reuptake inhibitors (SSRIs), serotoninnorepinephrine reuptake inhibitors (SNRIs), tricyclic antidepressants (TCAs), tetracyclic antidepressants (TeCAs) or by monaminoxidase inhibition (MAOls). Another way of elevating serotonin effects is direct $5-\mathrm{HT}_{1 \mathrm{~A}}$ agonism as for example azapirones do, commonly used as augmentation to other antidepressants.

Regarding the molecular $5-\mathrm{HT}_{1 \mathrm{~A}}$ mechanisms, activation of both the presynaptical and the postsynaptical receptors leads to neuronal hyperpolarization. Subsequently, this leads to reduced neuronal firing of raphe nucleus fibers as well as release of $5-\mathrm{HT}$ from terminals in the respective projection areas (Hjorth 1985). In addition to inhibiting $A C$ via $G_{i / 0}$ proteins and reducing cellular cAMP (Nebigil et al. 1995, De Vivo and Maayani 1986) 5-HT $\mathrm{HA}_{1 \mathrm{~A}}$ receptors trigger the opening of inwardly rectifying $K+(G I R K)$ channels via $G_{\beta \gamma}$ subunits (Andrade and Nicoll 1987, Penington et al. 1993) and the inhibition of ( $\mathrm{N}$ and $\mathrm{P} / \mathrm{Q}$-type) $\mathrm{Ca}^{2+}$ channels (Penington and Kelly 1990, Singh et al. 1996). Moreover, the 5- $\mathrm{HT}_{1 \mathrm{~A}}$ receptor activates the amiloride-sensitive $\mathrm{Na}^{+} / \mathrm{H}^{+}$exchanger (NHE) via $\mathrm{G}_{\mathrm{i} / \mathrm{o}}$ which regulates cellular volume and $\mathrm{pH}$ (Magro et al. 2007). The receptor also acts via the $G_{z}$ protein to increase the secretion of various neuroendocrine hormones (Serres et al. 2000). In the hippocampus, $5-\mathrm{HT}_{1 \mathrm{~A}}$ receptors are mainly present in the CA1 subregion. Here they exert influence on glutamergic functions via action on NMDA and AMPA receptors in pyramidal cells and by changing the activity of GABAergic interneurons (Ogren et al. 2008). Thus, serotonin serves as modulator especially for declarative memory tasks such as contextual, spatial learning. Recent molecular modeling of the $5-\mathrm{HT}_{1 \mathrm{~A}}$ receptor show that it is distinguished from the general GPCR structure among others by a considerably longer third intracellular loop which is important for G protein coupling (Paila et al. 2011). 


\begin{tabular}{|c|c|c|c|c|c|}
\hline Receptor & $\begin{array}{l}\text { Principal } \\
\text { G proteins }\end{array}$ & $\begin{array}{l}\text { Principal } \\
\text { signals }\end{array}$ & $\begin{array}{c}\text { Other } \\
\text { G } \\
\text { proteins }\end{array}$ & $\begin{array}{l}\text { Other direct } \\
\text { signals }\end{array}$ & $\begin{array}{c}\text { Downstream } \\
\text { signal } \\
\text { (mediator) }\end{array}$ \\
\hline $5-\mathrm{HT}_{1 \mathrm{~A}}$ & $\begin{array}{r}G_{i}(D R N) \\
G_{0}>G_{i}(C x, \\
\text { Hip, Hyp) }\end{array}$ & $\begin{array}{l}\text { AC and PKA (Cx, } \\
\text { Hip) (-) } \\
\mathrm{gK}^{+}(\mathrm{GIRK}) \\
(\mathrm{DRN})(+) \\
\mathrm{gCA}^{2+}(\mathrm{N}, \mathrm{P} / \mathrm{Q}) \\
(\mathrm{DRN})(-)\end{array}$ & $\begin{array}{l}\mathrm{G}_{z} \text { (Hyp, } \\
\text { Hip) }\end{array}$ & $\begin{array}{l}\text { PLC (Hip) (-) } \\
\text { PLA }_{2}(\text { HIP) (+) }\end{array}$ & $\begin{array}{l}\text { pERK (Hip, } \\
\text { DRN) (-) } \\
\text { pERK (Hyp) } \\
(+) \\
\text { pAkt (Hip) (+) } \\
\text { gK }{ }^{+}(\text {TWIK-1) } \\
(\text { Ecx })\end{array}$ \\
\hline $5-\mathrm{HT}_{7}$ & $\mathrm{G}_{\mathrm{s}}$ & $\begin{array}{l}\text { AC and PKA (Hip) } \\
(+)\end{array}$ & $\mathrm{G}_{12}(\mathrm{Hip})$ & $\begin{array}{l}\text { RhoA and } \\
\text { Cdc42 (Hip) } \\
(+) \\
\text { gK }^{+} \text {(striatum) } \\
(-) \\
\text { gCation } \\
\text { (globus } \\
\text { pallidus) (+) }\end{array}$ & $\begin{array}{l}\text { pERK (Hip) } \\
(+) \\
\mathrm{I}_{H} \text { current } \\
\text { (cAMP) (Hip, } \\
\text { striatum) (+) }\end{array}$ \\
\hline
\end{tabular}

Table 1.1 Coupling patterns $5-\mathrm{HT}_{1 \mathrm{~A}}$ and $5-\mathrm{HT}_{7}$

Modified according to Millan et al. (2008, P. 457). The table illustrates the main G protein coupling partners and principal signaling pathways of the serotonin receptors $5-\mathrm{HT}_{1 \mathrm{~A}}$ and $5-\mathrm{HT}_{7}$ without any claim to completeness. Abbreviations: (-), inhibition; (+), stimulation; $\mathrm{Cx}$, cortex; DRN, dorsal raphe nucleus; Ecx, entorhinal cortex; g, channel; Hip, hippocampus; Hyp, hypothalamus; $I_{H}$, hyperpolarisation-activated current; L,N,P/Q, types of $\mathrm{Ca}^{2+}$ channel; $p$, phosphorylated; Ras, Rap1, RhoA, Cdc42 are small GTPases; TWIK, tandem pore domain weakly inwardly rectifying $\mathrm{K}^{+}$channel.

\subsubsection{The $5-\mathrm{HT}_{7}$ receptor}

The $5-\mathrm{HT}_{7}$ receptor is the second object of study in this two receptor approach. It was first cloned in 1993 (Tsou et al. 1994). The $5-\mathrm{HT}_{7}$ receptor is present in the suprachiasmatic 
nucleus of the ventral hypothalamus, (Hedlund 2009) in thalamus, cortex and hippocampus. Besides, it is expressed in the gastrointestinal tract and in the vasculature, where it causes smooth muscle relaxation. The $5-\mathrm{HT}_{7}$ receptor is integrated in a variety of physiological functions such as learning and memory, hippocampal signaling, thermoregulation and circadian rhythm (Duncan et al. 1999, Lovenberg et al 1993, Hedlund 2009, Sprouse et al. 2004, Thomas et al. 2003) and disorders like depression (Hedlund 2009, Guscott et al. 2003). The $5-\mathrm{HT}_{7}$ receptor is linked to G-proteins $\mathrm{G}_{\mathrm{s}}$ (Bard et al. 1993, Tsou et al. 1994) and $\mathrm{G}_{12}$ (Kvachnina et al. 2005). Activation of $\mathrm{G}_{\mathrm{as}}$ results in stimulation of $A C$ and consequently in an increase of cyclic adenosine monophosphate (CAMP), which downstream activates protein kinase A (PKA), cAMP guanine nucleotide exchange factors (Epac1 and Epac2) and other cAMP dependent target molecules (eg. CNG-channels, CREB). Downstream, the cAMP-PKA signal transduction activates mitogen activated protein (MAP) kinases and extracellular signal regulated kinases (ERK) 1 and 2, whereas the latter seems also to be activated by the Epac pathway (Lin et al. 2003). $\mathrm{G}_{12}$ protein signaling causes activation of a serum response element (SRE) - mediated gene transcription via small GTPases, conceivably affecting neurite length and cyto-architecture (Kvachnina et al., 2005) (Tab. 1.1).

\subsection{Serotonin networks}

Messenger systems, such as the serotonergic system, are manifold, highly branched and deeply interconnected with other mediators. It is their nature as network to be influenced by a multitude of effectors and that a signal once initiated gets repeatedly converted and ramified in what is at the end a change of cell activity whatsoever. In these premises influences can be synergistic or antagonistic on certain signaling nodes. In the complex 5-HT messenger system different cellular configurations can be distinguished. Signal transduction involves multiple convergent inputs onto common integrative signals, which themselves display divergent (multiple) outputs. Released serotonin affects multiple receptors as for example 5$\mathrm{HT}_{1 \mathrm{~A}}$ and $5-\mathrm{HT}_{7}$. Their signals converge on the same mediator, $\mathrm{AC}$ which gets inhibited and activated, respectively. Other receptors such as $5-\mathrm{HT}_{7}$ and $5-\mathrm{HT}_{4}$ synergistically activate $\mathrm{AC}$. The counter-cooperatively mode of $5-\mathrm{HT}_{1 \mathrm{~A}}$ and $5-\mathrm{HT}_{7}$ illustrates the balanced control as universal feature of complex (signaling and supra-cellular) networks that is fundamental to homeostasis and favors resistance to disruption (Millan 2006). The AC constitutes another key link that controls the downstream targets PKA and Epac; this is termed pleiotropy (divergence/multiple roles). Other modes of network signaling also show modes of divergence and convergence such as bi-parallel, where 2 mediators mutually affect 2 targets or bi-fan, where a signal gets divided on a downstream level onto two different signaling 
points just to converge again on the subsequent level. Other configurations are the features of negative or positive feedback loops or fast-forward signaling in which a transmitter can skip a certain stage of the pathway (Fig. 1.5).
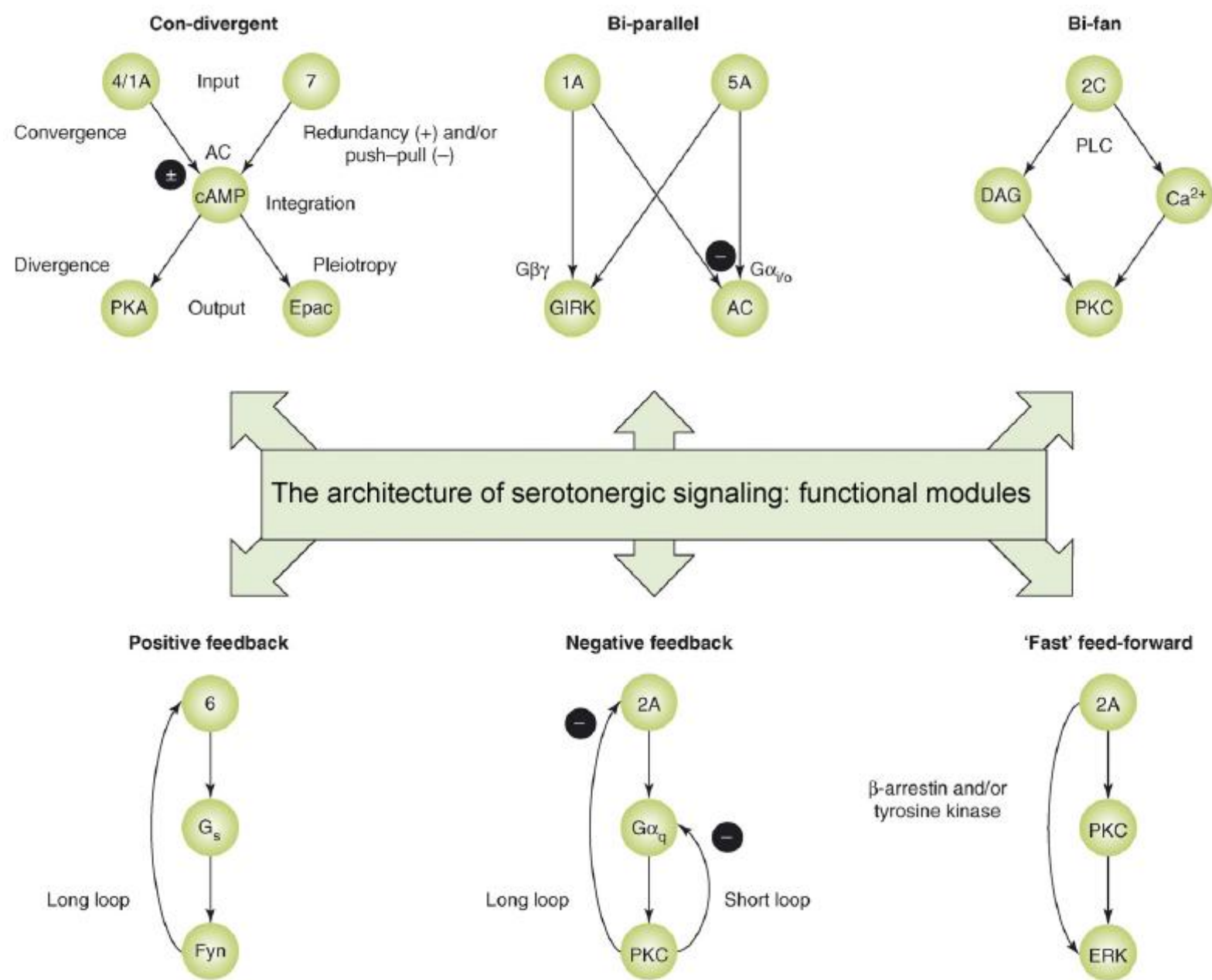

\section{Fig. 1.5 Modes of network signaling}

From Millan et al. (2008, P. 460). This model shows different kinds of messaging configurations on the basis of serotonin-signaling. Green circles represent the respective levels of sorotonergic pathways, whereby the number in each top circle corresponds to the respective 5-HT receptor. Abbreviations: DAG, diacylglycerol; Epac, exchange protein directly activated by cAMP; ERK, extracellular signal regulated kinases; Fyn, non receptor tyrosine kinase; GIRK, G protein coupled inward rectifier potassium channel; PKA, protein kinase a; PKC, protein kinase c; TK, tyrosine kinase;

But this is just where the promiscuity starts. On top of these well known features of a network comes crosstalk and interference on every level of signaling. It is becoming more evident that 
canonical GPCR pathways are not at all as strict and distinct as they were believed to be. Interference occurs on many levels of signal transmission, leading to bifurcations and providing higher sensitivity when opposing mediators e.g. GPCRs control certain effector concentrations (Milligan 1993).

\subsubsection{Promiscuity in 5-HT signaling pathways}

Interference and receptor cross-talk emerge on every level of signal transduction. When investigating a model of two receptors, as in this case $5-\mathrm{HT}_{1 \mathrm{~A}}$ and $5-\mathrm{HT}_{7}$, out of a complex messenger system it is essential to reflect about the different junctions within the signaling pathways with regard to the preliminary end product, cAMP. As precondition, when investigating promiscuity in 5-HT pathways, it is necessary always to analyze the same variant of a certain receptor. There can be considerable genetic diversity in receptors that respond to the same hormone or neurotransmitter and such genetic subtypes may be coexpressed in a single cell (Andressen et al. 2006). Different splice variants, editing variants and other polymorphisms which can be formed during the processes of transcription, translation and posttranslational modification (protein biosynthesis), can lead to multiple pharmacologically similar receptor subtypes, each of which is more selective for certain pathways (Milligan 1993). For the $5-\mathrm{HT}_{1 \mathrm{~A}}$ receptor no splice variants are known and the gene is intronless (Hannon and Hoyer 2008). Two polymorphisms, Glycerin ${ }^{22}$ to Serin and Isoleucine ${ }^{28}$ to Valine, have been found to alter the extracellular amino terminal region of the receptor $^{68}$ (Nakhai et al. 1995). For the $5-\mathrm{HT}_{7}$ receptor four different splice variants are known (5- $\mathrm{HT}_{7 \mathrm{a}}-5-\mathrm{HT}_{7 \mathrm{~d}}$ ) which differ in their C-termini (Heidmann et al. 1997). Nevertheless, no differences regarding pharmacology, signal transduction or tissue distribution have been found to date among these isoforms. Another feature termed "functional selectivity" enhances the complexity of 5-HT signaling. In general this means the ligand dependent selectivity for certain signal transduction pathways in one and the same receptor. Thus, Dimethyltryptamine (DMT) for example activates phospholipase A2 through $5-\mathrm{HT}_{2 \mathrm{~A}^{-}}$and 5$\mathrm{HT}_{\mathrm{C}}$ - receptors whereas serotonin causes phospholipase $\mathrm{C}$ activation through these receptors (Berg et al. 2005). This effect may explain the phenomenon that direct $5-\mathrm{HT}_{2}$ agonists have psychedelic effects, in contrast to compounds that indirectly increase serotonin signaling at the $5-\mathrm{HT}_{2}$ receptors, such as SSRIs. Accordingly, $5-\mathrm{HT}_{1 \mathrm{~A}}$ receptor agonists show dissimilar efficacies at diverse $G_{\alpha}$ protein isoforms $\left(G_{i 2}\right.$ versus $\left.G_{i 3}\right)$ and at the GIRK channels (Heusler et al. 2005, Raymond et al. 2001). A further mode of cross-talk is the above mentioned feature of phosphorylation. Since colocalized receptors can mutually trigger phosphorylation of other receptors via downstream enzymes and thereby modify 
signaling, this is an important mechanism of interconnection. As pointed out earlier phosphorylation can also result in receptor down regulation in the cell membrane through $\beta$ arrestin binding.

In addition, common protein partners like regulators of $G$ protein signaling (RGS) constitute a potential mode of cross-talk. RGS accelerate GTPase activity and thereby promote GTP hydrolysis by the alpha subunit of $G$ proteins. Ultimately, this leads to earlier determination of signal transduction (Gu et al. 2007). RGS also facilitate constitutive activity (coupling to $G_{i}$ ) of $5-\mathrm{HT}_{1 \mathrm{~A}}$ receptors (Seifert and Wenzel-Seifert 2002). As pointed out earlier, the $\mathrm{G}_{\beta y}$ subunit undertakes crucial functions in $5-\mathrm{HT}$ signaling. Since $\mathrm{G}_{\alpha}$ protein coupling to the $\mathrm{G}_{\beta \gamma}$ dimer shows little selectivity the shared pool of $G_{\beta \gamma}$ subunits may result in a form of cross-talk between 5-HT receptors (Woehler and Ponimaskin 2009). With regard to the topic of this thesis it is particularly interesting, that $G_{\beta \gamma}$ subunits have been found to do both activating and inhibiting AC (Nielsen et al. 1991). Nevertheless, these findings have been made under very special conditions which are not applicable to the actual thesis and are going to be discussed in detail below.

Additionally, signaling can take diverse paths dependent on the amount of available ligand. Accordingly, Eason et al. observed a2-adrenergic receptor coupling to $G_{i}$ proteins at low agonist concentrations while binding to $\mathrm{G}_{\mathrm{s}}$ proteins at high agonist concentrations (Eason et al. 1992). This implies a further important feature of 5-HT pathways; GPCR coupling to different $G$ proteins. Based on the $G_{i}-G_{s}$ mediated antagonism of the $5-H T$ receptors $5-H T_{1 A}$ and $5-\mathrm{HT}_{7}$, the degree of selectivity for these $\mathrm{G}$ proteins is immensely important to evaluate a common impact on cell activity.

Many GPCRs have the ability to interact and transduce signal through a variety of Gproteins, (Woehler et al. 2010) although receptors have distinct preferences in their G protein selection. Thus, the three $\alpha 2$ adrenergic receptors $\alpha 2 A-C$ display cholera toxin and pertussis toxin sensitive dual coupling to $G_{i}$ and $G_{s}$, respectively (Eason et al. 1992). In these premises, cholera toxin is known to inhibit $G_{s}$ protein signaling whereas pertussis toxin blocks $G_{i}$ signal transduction. Moreover, the human thyrotropin receptor is even capable of signaling trough members of all four $\mathrm{G}$ protein families (Laugwitz et al. 1996). Also the 5- $\mathrm{HT}_{4}$ receptor turned out to transduce signal through both $G_{i}$ and $G_{s}$ (Pindon et al. 2002). A further crosslinking occurs as a consequence of the phenomenon of GPCR oligomerization which can influence signaling patterns of ligand bound receptors in distinct ways and therefore augment the diversity of GPCR functions in many cases (Maggio et al. 2005, Rios et al. 2001, Urban et al. 2007, Renner et al. 2012). Hence, George (George 2000) and Gomes et al. (Gomes et al. 2000) revealed that $\mu$ - and $\delta$-opioid receptors form heterodimers and thereby generate a novel receptor pharmacology and $G$ protein coupling properties. They report that not only the 
potency and rank order of highly selective synthetic agonists for each receptor were changed in HEK293-cells co-expressing both receptors, but also that agonists and antagonists of one receptor can positively augment the efficacy and potency of the agonist of the associated receptor. Correspondingly, Rocheville (Rocheville 2000) demonstrated that the dopamine receptor D2R and the somatostatin receptor SSTR5 hetero-oligomerize and synergistically inhibit AC. Here, stimulation and inhibition of SSTR5 directly influence the D2R pathway before the G-protein decoupling step. In constitutive receptor complexes trans-inhibitory effects might occur, so that specific blockade of each respective receptor effectively blocks downstream signaling and trafficking of both receptors simultaneously, which was observed in case of $\beta$-adrenergic receptors ( $\beta A R s$ ) and angiotensin II type 1 receptors (AT $\left.{ }_{1} R s\right)$ (BarkiHarrington 2003). Many serotonin receptor subtypes, like 5- $\mathrm{HT}_{1 \mathrm{~A}}, 5-\mathrm{HT}_{1 \mathrm{~B}}, 5-\mathrm{HT} \mathrm{T}_{1 \mathrm{D}}, 5-\mathrm{HT}_{4}$ and 5- $\mathrm{HT}_{2 \mathrm{C}}$ also tend to form dimers or oligomers (Lee 2004, Woehler and Ponimaskin 2009, Kobe et al. 2008). Collaborating groups even showed that the receptor subtypes $5-\mathrm{HT}_{1 \mathrm{~A}}$ and $5-\mathrm{HT}_{7}$ hetero-oligomerize in vitro and in vivo and that hetero-oligomerization alters the functional behavior of the two receptors (Renner et al. 2012). Due to the manifold options of receptor interaction and cross-talk it seems likely that $5-\mathrm{HT}_{7}$ and $5-\mathrm{HT}_{1 \mathrm{~A}}$ receptors also interact on different levels of their signal cascades.

\subsection{Goal of thesis}

The serotonin receptor subtypes $5-\mathrm{HT}_{7}$ and $5-\mathrm{HT}_{1 \mathrm{~A}}$ work counter-cooperatively on the same effector, adenylyl cyclase $(A C)$, via $G_{s^{-}}$and $G_{i}$ proteins respectively. Both receptors are expressed in CA1 hippocampal neurons (Bickmeyer et al. 2002, Neumaier et al. 2001, Azmitia et al. 1996, Kia et al. 1996) and in the prefrontal cortex, where they are reported to play a key role in the postnatal development (Béique et al. 2004). Cooperating groups have detected both receptors within the same neuronal cells (Renner et al. 2012). Fig. 1.6 shows neurons and glia cells of the pre-Bötzinger complex that express both receptors simultaneously (kindly provided by Dr. Dr. Till Manzke). 
Introduction

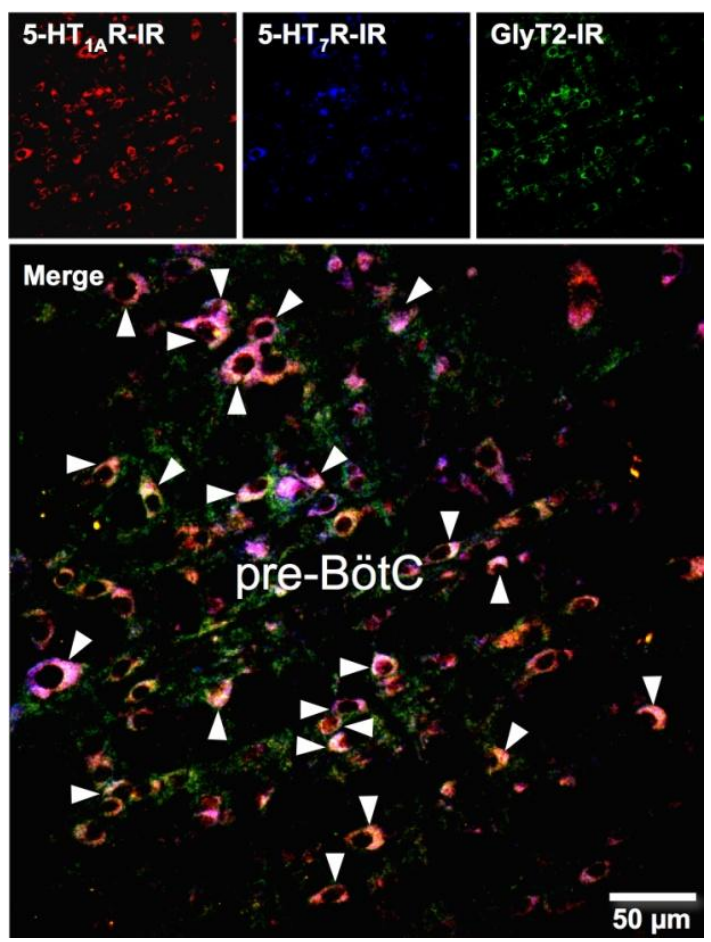

Fig. 1.6 $5-\mathrm{HT}_{1 \mathrm{~A}}-5-\mathrm{HT}_{7}$ coexpression in neurons and glia cells of the pre-Bötzinger complex

Kindly provided by Dr.Dr. Till Manzke. The picture shows rodent neurons and glia cells in the preBötzinger complex labeled with fluorescent antibodies against 5- $\mathrm{HT}_{1 \mathrm{~A}^{-}}$(red, top line, left), 5- $\mathrm{HT}_{7^{-}}$(blue, top line, middle) and GlyT2 receptors (green, top line, right). White arrows in the bottom line picture indicate cells which coexpress $5-\mathrm{HT}_{1 \mathrm{~A}}$ and $5-\mathrm{HT}_{7}$.

The physiological occurrence of both receptors in the same cells raises the question how their contrary influences merge on the adenylyl cyclase. The work in hand shall characterize the $5-\mathrm{HT}_{1 \mathrm{~A}}-5-\mathrm{HT}_{7}$ receptor interaction with regard to the cAMP concentration as a quantity to be measured. As low levels of cAMP primarily activate PKA whereas higher levels favor Epac activation, (Murray et al. 2009) [CAMP] determines the major downstream pathway. Mutual signal extinction, privilege of one pathway or a phase-shifted signal as result of 5$\mathrm{HT}_{1 \mathrm{~A}}-5-\mathrm{HT}_{7}$ cross-talk are conceivable. A live imaging FRET approach for cAMP concentration measurements was chosen so that single cells could be taken for analysis, which coexpressed both receptors. This method allowed observing cAMP production under physiological conditions. 


\section{Material and methods}

\subsection{FRET imaging}

Classical approaches to analyze receptor-mediated changes in intracellular [CAMP] so as radioactive tracking of ATP metabolism cannot provide exact, quantitative information in high temporal and spatial resolution within single cells. In this thesis Förster resonance energy transfer (FRET) between two fluorophores was used to determine the real-time course of cAMP levels upon receptor stimulation in living cells. In this kind of energy transfer a donor fluorophore (D) is excited by light of the appropriate wavelength and, in its electronic excited state, transfers energy when falling back in its basal state to an acceptor (A) fluorophore through nonradiative dipole-dipole coupling. Therefore these two fluorophores have to be in very close proximity. The transfer results in excitation of $A$. Subsequently, the induced fluorescence emission both from the donor as well as from the acceptor can be measured. To apply this energy transfer on [cAMP] measurements a special biosensor was taken which uses the cAMP activated GTPase exchange factor Epac1, (De Rooij et al. 2000, Ponimaskin et al. 2007) as backbone. This approach is based on a special FRET pair tandem construct and a measuring method first described by Adams et al. (Adams et al. 1991). Ponsioen et al. (Ponsioen et al. 2004) applied this method on the described Epac construct which was then further developed in this department and by collaborating groups (Salonikidis et al. 2008, Salonikidis et al. 2011). The Epac1 based construct (in the following called "CEPAC*") is fused to the fluorophore mCerulean (D) (Rizzo et al. 2004, Rizzo et al. 2006) at its amino terminus, whereas the carboxy terminus is fused to mCitrine (A) (Griesbeck 2001). In addition, the DEP domain which is responsible for membrane localization of Epac1 was deleted and inserted mutations prevent Rap1 activation (Ponsioen et al. 2004). cAMP binding at the cAMP binding domain induces a conformational change of the Epac1 protein, resulting in a distance and/or orientation change between the fluorophores of the FRET pair. Consequently, the energy transfer between the two fluorophores is interrupted and the intensity ratio between donor and acceptor emission changes (Fig. 2.1). A reduction of intracellular CAMP therefore increases the energy transfer between mCerulean and mCitrine while a [CAMP] rise diminishes FRET (Ponsioen et al. 2004, Ponimaskin et al. 2007). 


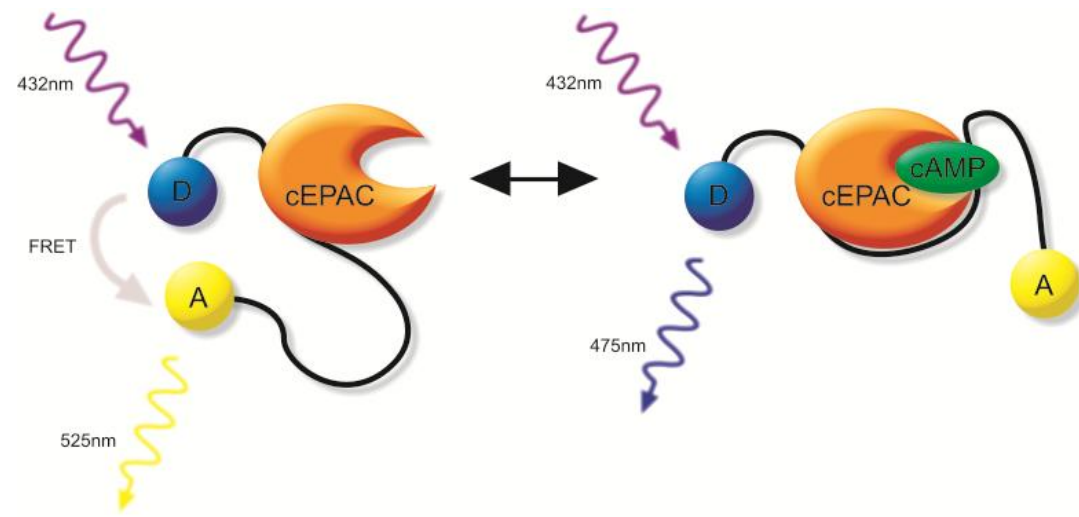

\section{Fig. 2.1 Förster resonance energy transfer of the CEPAC* tandem construct}

Modiefied according to Bos (2003, P. 734) and Ponsioen et al. (2004, P. 1177). The model shows a conformational change of the FRET-sensor-construct (Donor-Epac (סDEP-CD)-Acceptor) induced by CAMP binding to the regulatory domain of EPAC. The distance between the two fluorophores increases after CAMP-binding, resulting in a decrease of FRET intensity. Consequently, an increase of FRET intensity (EfDA/Y) corresponds to a decrease of intracellular [cAMP]. Abbreviations: EPAC, exchange protein directly activated by CAMP; CEPAC ${ }^{*}$, FRET-sensor-construct using mCerulean and mCitrine as FRET-pair, D, donor; A, acceptor.

As the model shows, the FRET-sensor-construct (CEPAC*) can be in two states of FRET efficiency $\left(E_{1}\right.$ and $\left.E_{2}\right)$. Due to binding or unbinding of CAMP the fraction $\left(f_{D A}\right)$ of CEPAC* molecules in a higher FRET state changes and consequently the apparent FRET efficiency $\triangle E f_{D A}$ of the total amount of biosensor molecules (with $\triangle E=E_{1}-E_{2}$ ). The FRET value $\triangle E f_{D A}$ of CEPAC* becomes a function of the CAMP concentration present. Measuring the emission spectra at both D- and A- excitation wavelengths in three different filter sets allows [CAMP] detection in a quantitative manner over the course of time.

\subsubsection{Construction of expression plasmids}

The plasmids that encode for mCerulean and mCitrine were obtained from ADDGENE. The coding sequences were amplified by PCR introducing recombinant recognition sites for restriction enzymes using the primers: mCerulean-for (5'- -3'), mCerulean-rev (5'- -3'), mCitrine-for (5'- -3') and mCitrine-rev (5'- -3'). The resulting PCR products were subcloned into the mammalian expression vector pTarget (PROMEGA), which served as positive control in FRET measurements. mCerulean and mCitrine were isolated from these vectors with the restriction enzyme pairs Notl/EcoRV and Nhel/Ecorl (NEW ENGLAND BIOLABS), respectively, 
and cloned into the corresponding sites in the vector pcDNA3.1-CFP-Epac(סDEP-CD)-YFP, replacing the previous fluorophores, thus creating the new plasmid CEPAC*.

\subsubsection{Microscopy}

The FRET experiments were done with an upright epifluorescence microscope, equipped with a water immersion objective (XLUMPlanFI, 20x, NA 0.95, OLYMPUS, Germany). The exciation light came from a $100 \mathrm{~W}$ xenon lamp attached to a monochromator (OPTOSCAN, KINETIC IMAGING) which was coupled to the microscope via fibre optics. The experimental setup and evaluation required the use of two excitation wavelengths that were 420/10 nm $\left(\lambda^{1}\right)$ and 510/10 $\mathrm{nm}\left(\lambda^{2}\right)$, called donor and acceptor excitation, respectively. A dichroic mirror $(505 \mathrm{~nm})$ was taken to separate emission from excitation light and passed the light into the objective pathway to excite the specimen. According to its properties, the higher intensity of the second excitation wavelength was much less reflected and thus, similar intensities were obtained at the two excitation wavelengths, 420/10 nm and 500/10 nm. Using a DUALVIEW (OPTICAL INSIGHTS, Tucson, Arizona, USA), the fluorescence emission signal was split by a dichroic mirror $(515 \mathrm{~nm}$ ) into $470 / 30 \mathrm{~nm}$ for the donor channel and 535/30 nm for the acceptor channel. With an IXON camera DV887DCS (ANDOR TECHNOLOGY, South Windsor, CT, USA), three principle images were acquired: (a) the donor image at donor excitation and donor emission wavelength, (b) the FRET image at donor excitation and acceptor emission wavelength, (c) the acceptor image at acceptor excitation and acceptor emission wavelength. The excitation exposure times should not be too long to avoid bleaching of the fluorophores. On the other hand they have to be long enough depending on the fluorophore expression and emission intensities of the cells. Times about $1 \mathrm{sec}$ were chosen so that bleaching was not significant. 


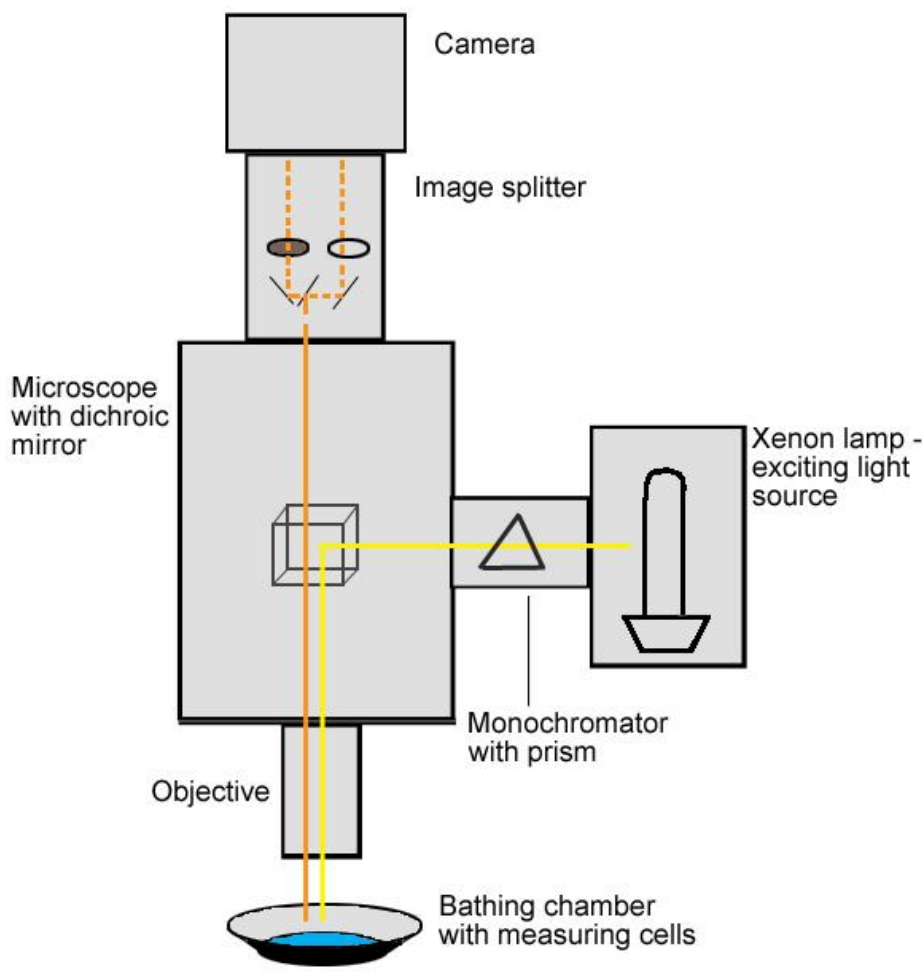

Fig. 2.2 Microscope and pathways of excitation and emission lights

The model shows the configuration of the microscope setup. Yellow line, excitation light divided by a dichroic mirror from emission light (orange line) which is split into the donor channel and acceptor channel by another set of dichroic mirrors (image splitter).

The experimental microscopic pictures were corrected for the background and for the inhomogeneous illumination according to the specific excitation wavelengths. The background image was acquired under the same settings as in the FRET experiments without excitation light. The inhomogeneous illumination was recorded by fluorescent slides (Chroma Technology, Rockingham, VT). Subpixel shifts between the donor and acceptor emission channel as result of imperfect alignment of the Dual View were corrected with the help of a reference grid structure.

\subsubsection{Data analysis, acquisition of the $E f_{D A} / Y$ value}

As mentioned above FRET appearance will increase in cAMP absence and decrease in presence of CAMP. If the FRET efficiency $E$ is high, a strong acceptor emission will be apparent, whereas in case of FRET efficiency decrease the A emission will also diminish in 
favor of a stronger donor emission. Traditionally, the ratio between the emission intensities, deriving from $D$ (mCerulean), and those deriving from $A$ (mCitrine), was used as a FRET equivalent measure, whereas FRET is inversely proportional to the ratio. These FRET ratio measurements are usually done at a single excition wavelength, optimal for donor excitation. However, this measure cannot distinguish between FRET and non-FRET signals and is consequently unable to analyze absolute values of FRET or [CAMP], respectively. Hence, Hoppe et al. (Hoppe et al. 2002) developed a stoichiometric method that uses two excitation wavelengths and three filter sets to measure the FRET efficiency and the relative concentrations of donor and acceptor, as well as the fractions of donor and acceptor in complex. This method was further developed and applied on the Epac1 tandem construct CEPAC* in this department by Salonikidis et al. (Salonikidis et al. 2008). In the following, the term $E f_{D A} / y$, illustrating the FRET value, is used as response signal. $f_{D A}$ is the fraction of the total CEPAC* molecules which are in FRET state and $y$ is the ratio of the donor and acceptor extinction coefficients which is difficult to obtain and not necessary to analyze in this approach.

The $E f_{D A} / Y$ value is calculated pixelwise (Eq. 1) using the fluorescence intensity $F$ of the three different camera images ( $a, b$ and $c$ ) acquired during FRET measurements as described in chapter 2.1.2 Microscopy:
a: $F_{e x_{\lambda} D, e \lambda_{\lambda} D}^{C E P A C}, \mathrm{~b}$
b: $F_{e x}^{C E P A C}$
C: $F_{e x}^{C E P A C}, x_{\lambda^{A}}^{C E \lambda_{\lambda^{A}}}$,

with the indices: ex_A_D: at donor excitation wavelength; ex_ $\lambda \_A$ : at acceptor excitation wavelength; em_ $\lambda \_D$ : donor emission channel; em_ $\lambda \_$A: acceptor emission channel

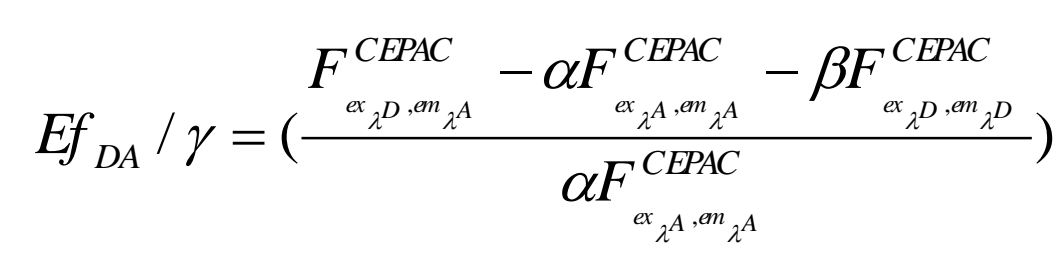

(Eq. 1, According to Salonikidis et al. 2008)

$\alpha=\frac{F_{e x_{\lambda^{D}}, e m_{\lambda^{A}}}^{A}}{F_{e x_{\lambda^{A}}, e m_{\lambda^{A}}}^{A}}$ constitutes the relative acceptor fluorescence signal and was acquired in acceptor only measurements. $\beta=\frac{F_{e x_{\lambda^{A}}^{A}, e m_{\lambda^{A}}}^{A}}{F_{e x_{\lambda^{D}}^{A}, e m_{\lambda^{A}}}^{A}}$ is the fraction of donor emission in the 
acceptor emission channel, often called bleedthrough and is also derived from separate donor and acceptor measurements. All calculations were performed with MATLAB (MathWorks, Natick, MA) and the DIPimage Toolbox (image processing toolbox for Matlab, Delft University of Technology, Netherlands) using MATLAB scripts programmed by Guobin Bao.

\subsubsection{CEPAC* calibration}

As pointed out earlier the $E f_{D A} / Y$ value is inversely proportional to [CAMP] and can be expressed as a function of [CAMP].

$E f_{D A} / \gamma=f([c A M P)]$

For this calibration of the [CAMP] sensitivity of CEPAC* the "sensitized emission" FRET signal was recorded in fluorescence spectrometry measurements by $P$. Salonikidis as described in Salonikidis 2011 (Salonikidis et al. 2011).

The detected CEPAC* fluorescence signal $F^{i}(\lambda)$ at an excitation wavelength $\lambda^{i}$ consists of a part of donor emission (here represented by $F_{D}^{r e f}(\lambda)$ ) and a part of acceptor emission (here represented by $F_{A}^{r e f}(\lambda)$ ). The fraction of each emission signal can be derived by fitting the linear combination of the respective $\mathrm{D}$ and $\mathrm{A}$ reference spectra $\left(F_{D}^{r e f}(\lambda), F_{A}^{r e f}(\lambda)\right)$ to the detected emission characteristic. (Eq. 2)

$F^{i}(\lambda)=\left[D^{i}\right] F_{D}^{r e f}(\lambda)+\left[A^{i}\right] F_{A}^{r e f}(\lambda)$

(Eq. 2, According to Salonikidis et al. 2008)

$\left[D^{i}\right]$ and $\left[A^{i}\right]$ are the apparent $\mathrm{D}$ - and $\mathrm{A}$ concentrations which were used as fitting factors. Calibration was done for $D$ excitation wavelength $(i=1)$ and for $A$ excitation wavelength $(i=2)$. The $D$ and $A$ reference spectra must be obtained separately in cells containing only donor or only acceptor fluorophores.

The apparent acceptor concentrations at $D$ excitation $\left[A^{1}\right]$ and at $A$ excitation $\left[A^{2}\right]$ were used to deduce the following term (Eq. 3) (See also Eq. 1). 


$$
E f_{D A} / \gamma=\frac{\left[A^{1}\right]-\alpha\left[A^{2}\right]}{\alpha\left[A^{2}\right]}
$$

(Eq. 3, According to Salonikidis et al. 2008)

Again, $\alpha$ constitutes the ratio of the relative acceptor emission intensities at both wavelengths applied.

The [CAMP] dependence of $\mathrm{Ef}_{\mathrm{DA}} / \mathrm{Y}$ can be expressed by a Hill equation which describes the binding equilibrium of a ligand to a macromolecule in the presence of other ligands (Eq. 4).

$$
E_{D A} / \gamma=\left(p_{\mathrm{m} \text { a }}-p_{0}\right) \frac{[c A M P]^{n_{H}}}{\left(E C_{50}\right)^{n_{H}}-[c A M P]^{n_{H}}}+p_{o}
$$

(Eq. 4, According to Salonikidis et al. 2008)

where $n_{H}$ is the Hill coefficient indicating the amount of cAMP binding places. $p_{0}$ and $p_{\max }$ are offset and maximum amplitude parameters and $E C_{50}$ is the [CAMP] when $50 \%$ of the cAMP binding sites are occupied. Again, $E f_{D A} / V$ is inversely proportional to the cAMP concentration.

With help of these calculations the measured $E f_{D A} / Y$ values can be converted into [cAMP] values.

\subsubsection{Excitation and emission spectra}

Optimal excitation and emission wavelengths have been determined in previous measurements. Figure 2.4 reveals the mCerulean and mCitrine fluorescence emission spectra. 


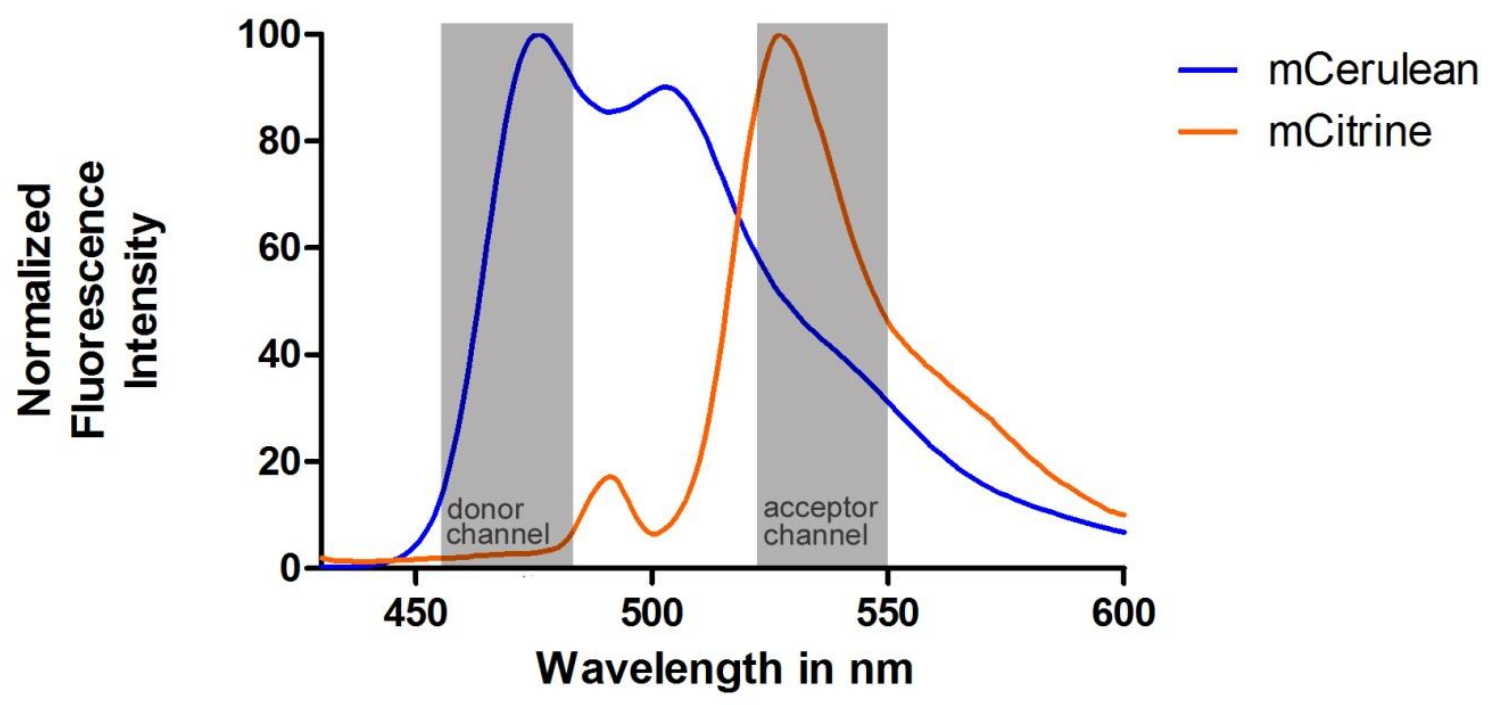

Fig. 2.3 mCerulean and mCitrine emission spectra

The image shows the respective emission spectra of mCerulean (blue line) with a peak at $475 \mathrm{~nm}$ and $\mathrm{mCitrine} \mathrm{(orange} \mathrm{line)} \mathrm{with} \mathrm{a} \mathrm{peak} \mathrm{at} 526 \mathrm{~nm}$, recorded in fluorescence spectrometry measurements by $P$. Salonikidis in $n=5$ experiments. The second peak in the mCerulean curve $(500 \mathrm{~nm})$ is due to the raman effect which occurs in cuvette measurements and can be corrected in analysis protocols. Grey bars indicate the respective channels for donor $(470 / 30 \mathrm{~nm})$ or acceptor $(535 / 30 \mathrm{~nm})$.

It is important to note that the chosen channel for donor emission (left grey bar in Fig. 2.3) does hardly contain any acceptor emission. In contrast it is not possible entirely to exclude donor emission in the emission light of the acceptor filter set (right grey bar in Fig. 2.3). This bleedthrough is corrected for each measurement. (See above)

In order to detect and distinguish the two coexpressed receptor subtypes on a single cell level under the microscope, $5-\mathrm{HT}_{7}$ receptors were tagged with the $\mathrm{N}$-terminal fluorescent protein mCherry (Promega). Prior to FRET measurements $5-\mathrm{HT}_{7}$ expression was confirmed through fluorescence identification using a red light filter at excitation wavelength of $580 \mathrm{~nm}$ and emission detection at $620 \mathrm{~nm}$. Figure 2.4 shows the mCherry emission spectrum. 


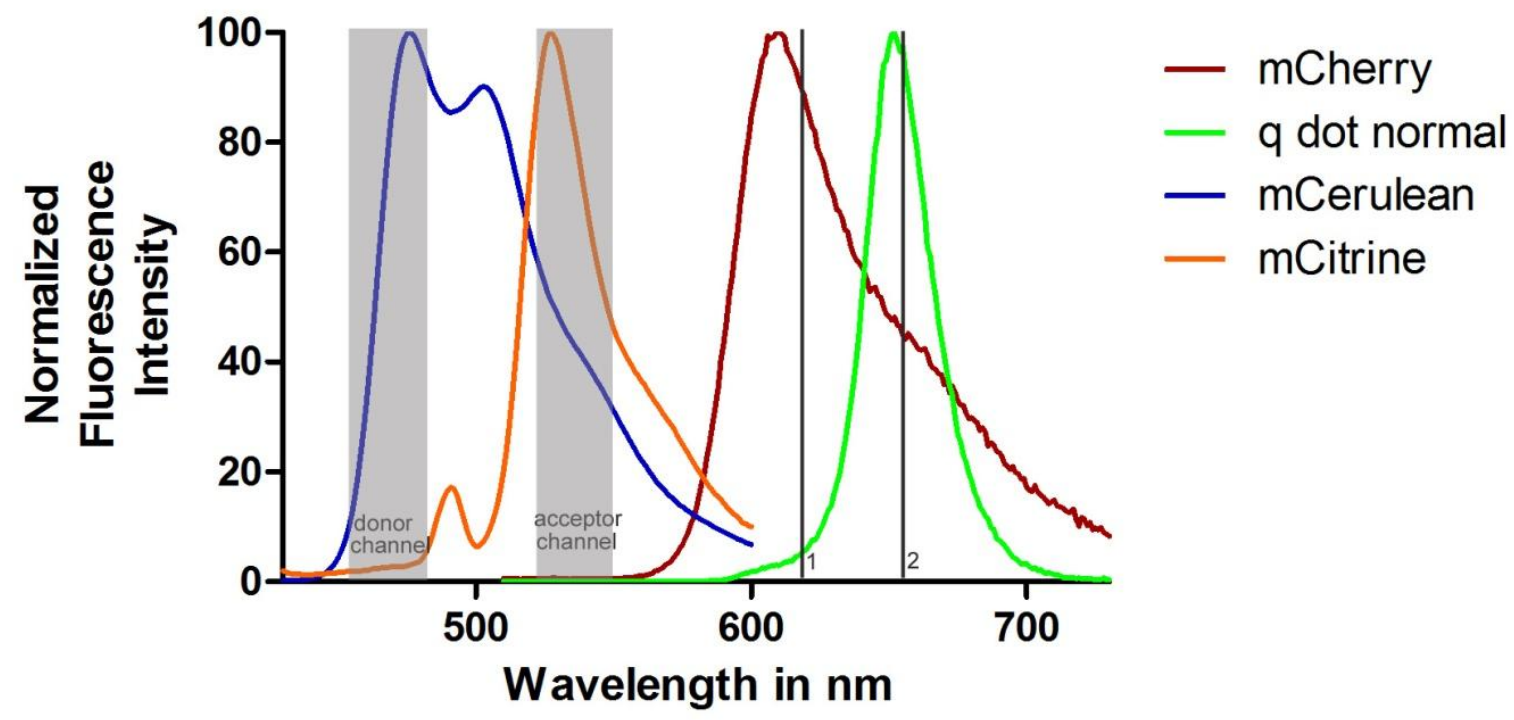

Fig. 2.4 mCherry and quantum dot emission spectra

The image depicts the emission spectra of mCherry (dark red) with a peak at $606 \mathrm{~nm}$ and quantum dots (green) with a peak at $650 \mathrm{~nm}$, recorded in fluorescence spectrometry measurements. mCherry and mCerulean emission spectra are shown as in Fig. 2.3. Black line 1 indicates mCherry filter (620 $\mathrm{nm})$, black line 2 indicates QD filter (655 nm).

$5-\mathrm{HT}_{1 \mathrm{~A}}$ receptors however were labeled with quantum dots (QD) (Invitrogen) recognizing antibodies against $\mathrm{HA}$ tags of recombinantly expressed $5-\mathrm{HT}_{1 \mathrm{~A}}$ receptors. Pictures were taken prior to FRET experiments to ensure 5- $\mathrm{HT}_{1 \mathrm{~A}}$ expression. Quantum dots were recorded with a QD filter set at 655nm (Fig. 2.4). Fig. 2.4 also reveals that mCherry and also QD emission does not appear in the donor or acceptor channel.

In control experiments with non-tagged receptors, we verified that neither the $\mathrm{N}$-terminal fluorescent tags nor QD labeling affected agonist affinity or signal transduction.

Figure 2.5 shows the development of donor and acceptor emission upon increasing [CAMP] indicated by the gray arrows. The higher [CAMP] rises, the bigger is the contribution of donor emission and the lower the contribution of acceptor emission to the biosensor emission signal at $420 \mathrm{~nm}$ excitation (see Eq. 1). The curve shapes of donor and acceptor reference spectra were obtained by separate measurements. All presented spectra are corrected for background and autofluorescence (Salonikidis et al. 2011). 


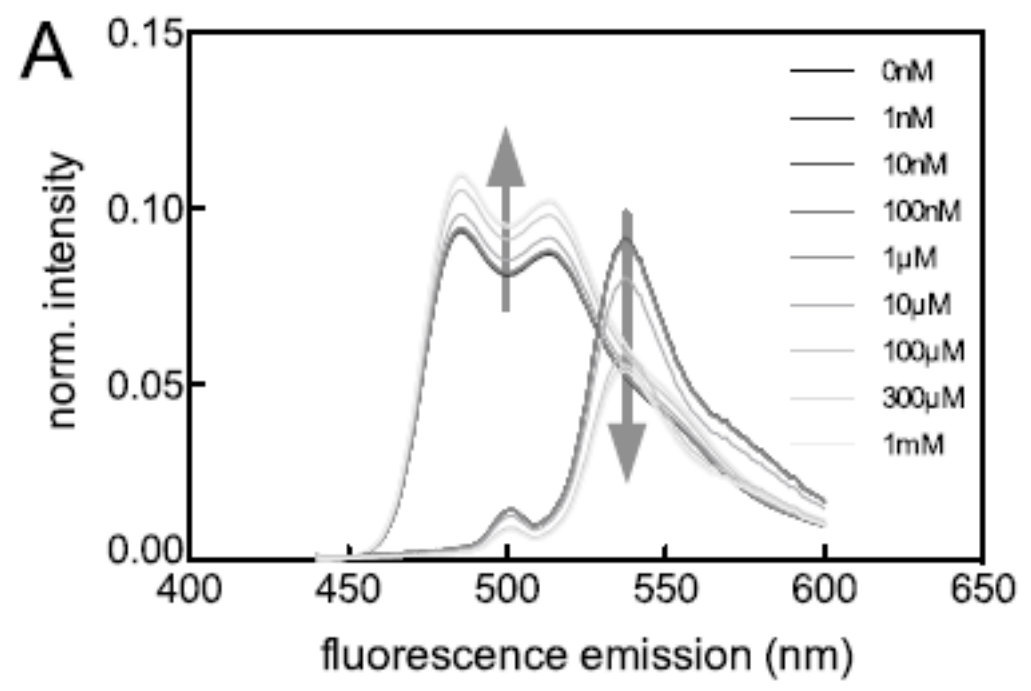

Figure 2.5 [CAMP] dependent donor and acceptor emission in CEPAC*

From Salonikidis et al. (2011. P. 23423) [CAMP] dependent CEPAC* emission spectrum. Spectra were obtained from a diluted supernatant of homogenized and centrifuged CEPAC*. CAMP was directly applied into the supernatant solution. CEPAC* emission spectra were unmixed into linear fractions of $m$ Cerulean and $m C i t r i n e$ reference spectra. Curve shapes of these reference spectra were obtained by separate measurements.

\subsection{Cell culture and transfection}

Mouse N1E-115 neuroblastoma cells from the American Type Culture collection (LGC Promochem, Wesel, Germany) were cultered in DULBECCo's MODIFIED EAGLE'S MEDIUM (SIGMA-ALDRICH, Munich, Germany) containing 10\% fetal calf serum (FCS) and $1 \%$ of a mix of penicillin and streptomycin at $37^{\circ} \mathrm{C}$ under $5 \% \mathrm{CO}_{2}$. Twenty-four hours before transient transfection, the neuroblastoma cells were seeded at low-density $\left(1 \times 10^{6}\right.$ cells $)$ in $10 \mathrm{~mm}$ dishes including glass covers slips on the bottom (for microscopic measurements). The cells were transfected with appropriate vectors using LIPOFECTAMINE2000 reagent (INVITROGEN) according to the manufacturer's instruction. The transfected cDNA was encoding for following proteins: (a) mCerulean monomeric cyan fluorescence protein (pECFP-N1, ClONTECH LABORATORIES, Mountain View, CA, USA), (b) mCitrine monomeric yellow fluorescence protein (pEYFP-N1, CLONTECH LABORATORIES), (c) the CEPAC* construct mCitrine-Epac( $\triangle D E P-C D)-m$ Cerulean in a pCDNA3 from Ponsioen et al. (Ponsioen et al. 2004), (d) mCherry (Promega), or (e,f,g,h) a cotransfection of either the HA/pTargetmCherry-tagged 5- $\mathrm{HT}_{1 \mathrm{~A}}$ receptor or/and the myc-/pTargetmCherry-tagged $5-\mathrm{HT}_{7}$ receptor cloned into the pcDNA3.1 plasmid together with CEPAC*. Cells for experiments on the $G$ Protein level were additionally transfected with cDNA encoding for following proteins: (i) Dominant inactive $G_{i}$ alpha subunit ( $G i \alpha 3$ Q 202T d/n), or (j) permanent active $G_{s}$ alpha 
subunit (Gsa Q227C). Three hours after transfection, cells were serum starved over night before analysis. Continuative incubation led to an aggregation of the CEPAC*-proteins.

\subsubsection{Treatment with pertussis toxin}

Pertussis toxin (PT) inhibits the $G_{i}$ alpha subunit of $G$ proteins through ADP-ribosylation. PT was used to determine which $\mathrm{G}$ protein pathway is preferred in $5-\mathrm{HT}_{1 \mathrm{~A}}$ and $5-\mathrm{HT}_{7}$ receptor coexpressing cells. Transfected N1E-115 cells were incubated with PT for 16 hours prior to analysis, at a concentration of $0.1 \mu \mathrm{g} / \mathrm{ml}$ diluted in standard culture medium (Griffin et al. 2007).

\subsubsection{Quantum dot staining}

As part of receptor expression analysis $5-\mathrm{HT}_{1 \mathrm{~A}}$ receptors were detected in living cells through labeling with quantum dots. As there are no anti-5-HT receptor antibodies available that recognize extracellular loops of 5-HT receptors, antibodies directed against $\mathrm{HA}$ - and myctags (Santa Cruz) of recombinantly expressed 5-HT receptors were used to couple quantum dots to the surface of the cells. Cells were incubated with 1 ng of primary antibody diluted in OptiMEM for $5 \mathrm{~min}$ and were extensivly washed with OptiMEM before addition of $1 \mathrm{nM} Q D$ Fab conjugates (Invitrogen) in QptiMEM for $5 \mathrm{~min}$. QDs were removed by extensive washing over a period of $10 \mathrm{~min}$.

\subsection{Solutions, agonists and antagonists}

During experiments cells were kept in tyrode solution (table 2.1). For preparation the listed chemicals were diluted in appropriate amount of distilled water. Afterwards solution was adjusted to a $\mathrm{pH}$ of 7.4 using a $\mathrm{pH}$ meter and $1 \mathrm{M} \mathrm{NaOH}$. The osmolarity was $340 \mathrm{mOsm}$. 


\begin{tabular}{|c|c|c|c|c|c|c|c|}
\hline Ingredient & $\mathrm{NaCl}$ & $\mathrm{KCL}$ & $\mathrm{CaCl}_{2}$ & $\mathrm{MgCl}_{2}$ & HEPES & $\begin{array}{l}\text { Sodium- } \\
\text { D- } \\
\text { glucose }\end{array}$ & Forskolin \\
\hline $\begin{array}{l}\text { Concentration } \\
\text { in } \mathrm{mM}\end{array}$ & 150 & 5 & 2 & 1 & 10 & 10 & 100 \\
\hline
\end{tabular}

Table 2.1, Content tyrode solution, pH7.4, osmolarity 340 mOsm.

Forskolin is a known $\mathrm{AC}$ activator and therefore raises the level of intracellular cAMP (Takeda et al. 1983). A Forskolin concentration of $100 \mathrm{nM}$ in bathing solution was chosen in order to ensure a mean cellular cAMP level, which allows the cAMP concentration to decrease or to increase after $5-\mathrm{HT}$-stimulation. $100 \mathrm{nM}$ is according to the $\mathrm{EC}_{50}$ value $(98 \pm$ $45 \mathrm{nM}$ ) of Forskolin, which was previously determined from colleagues (Guobin Bao, data not published) in separate experiments ( $\mathrm{n}=86$ cells) for our cell model, using $E f_{D A} / V$ as a response signal. Before measurements, cells were incubated for about 10 min in Forskolin (Fluka; 47735, EC No. 2664109). Selective agonists and antagonists in $5-\mathrm{HT}_{1 \mathrm{~A}}, 5-\mathrm{HT}_{7}$ coexpression experiments had to be applied in concentrations high enough to excite or inhibit the particular preferential receptor but low enough to not affect the other respective receptor. In control experiments with single receptor expression the same concentrations of agonists and antagonists were used to guarantee same conditions. Serotonin (SigmaAldrich) was supposed to activate both receptors and was given in a concentration of $1 \mu \mathrm{M}$ (Andressen et al. 2006, Sharif et al. 2004). Alternatively, 5- $\mathrm{HT}_{1 \mathrm{~A}}$ stimulation was realized by application of $1 \mu \mathrm{M}$ 8-OH-DPAT (TOCRIS BIOSCIENCE, Bristol, UK) and $5-\mathrm{HT}_{7}$ stimulation was mediated by application of $1 \mu \mathrm{M} 5$-Carboxamidotryptamine ( $1 \mu \mathrm{M}$ 5-CT, TOCRIS BIOSCIENCE, Bristol, UK), or 100nM AS19 ((2S)-(+)-5-(1,3,5-Trimethylpyrazol-4-yl)-2-(dimethylami no)tetralin) (TOCRIS BIOSCIENCE, Bristol, UK). AS19 is a selective 5-HT 7 agonist with only moderate affinity for $5-\mathrm{HT}_{1 \mathrm{~A}}$. The $\mathrm{K}_{\mathrm{i}}$ values, displaying the affinity of the agonists (Cer et al. 2009) are $4.6 \mathrm{nM}$ for $5-\mathrm{HT}_{7}$ and $110 \mathrm{nM}$ for $5-\mathrm{HT}_{1 \mathrm{~A}}$ (Bosker et al. 2009). The reason that AS19 was given in a slightly higher concentration than the $K_{i}$ values would suggest may be due to dilution effects in the experimental chamber at these very low concentrations. Control measurements excluded an affect of $100 \mathrm{nM}$ AS19 on 5-HT $\mathrm{T}_{1 \mathrm{~A}}$ receptors in the conducted experiments (Fig. 3.10). In order to block receptor stimulation the potent and selective $5-\mathrm{HT}_{7}$ receptor antagonist SB-269970-A (Sigma-Aldrich) (Lovell et al. 2000, Hagan et al. 2000) had 
been applied at a concentration about $1 \mu \mathrm{M}$. The corresponding $\mathrm{K}_{\mathrm{i}}$ values are $1.26 \mathrm{nM}$ for 5 $\mathrm{HT}_{7}$ and over $1 \mu \mathrm{M}$ for $5-\mathrm{HT}_{1 \mathrm{~A}}$ according to the manufacturer. The potent, selective and silent $5-\mathrm{HT}_{1 \mathrm{~A}}$ receptor antagonist WAY-100635 (Tocris) (Fletcher et al. 1996) was used at $1 \mu \mathrm{M}$ to inhibit $5-\mathrm{HT}_{1 \mathrm{~A}}$. Pharmacological profiling by Chemel et al revealed $\mathrm{K}_{\mathrm{i}}$ values of $2.2 \mathrm{nM}$ and > 10,000 $\mathrm{nM}$ for $5-\mathrm{HT}_{1 \mathrm{~A}}$ and $5-\mathrm{HT}_{7}$, respectively (Chemel et al. 2006). Control experiments confirmed selectivity of used agonists and agonists in all further experiments.

\subsection{Widefield fluorescence microscopy}

\subsubsection{Experimental setup}

The measuring setup for microscopy and fluorescence excitation is placed on a vibrationcushioned desk and surrounded by a Faraday cage. (Fig. 2.6) Underneath the objective of the upright microscope that is configured as pointed out above is the bathing chamber located on the object table. (Fig. 2.7) The chamber is embedded in a Plexiglas plate. The bottom is build of a picture frame glass $(30 \mathrm{~mm} \varnothing$, thickness $0,13 \mathrm{~mm}$ ) which is attached to the bottom side of the Plexiglas with Vaseline. The chamber has a total volume of ca $500 \mu$ l. It is equipped with a solution inflow through plastic tubes connected to elevated containers. The speed of inflow could be adjusted through a drip system. A valve system allowed the choice of the desired solution. The solution was sucked out of the bath chamber with a flexible-tube pump. The inflow was adjusted on 1 drop per second and the suction accordingly to ensure a smooth solution exchange. The different solutions could therefore be applied rapidly to the imaging chamber to quickly reach the final concentrations indicated above. The object table can be moved freely underneath the objectives. 


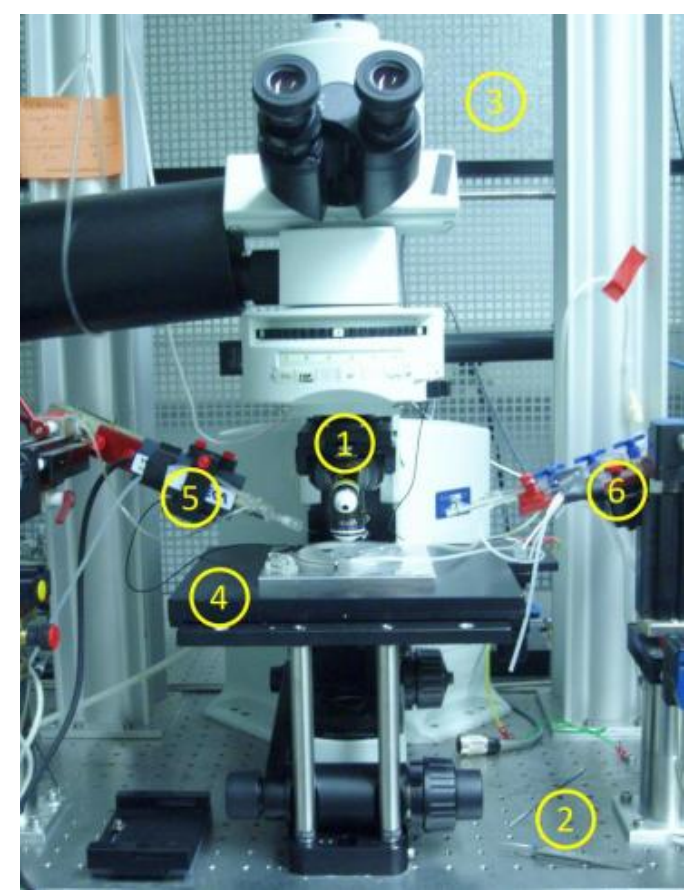

Fig. 2.6 Microscope setup

From Biophysikalisches Praktikum (Salonikidis 2003) The picture shows the experimental setup. 1, upright microscope; 2, vibration-cushioned desk; 3, Faraday cage; 4, object table; 5, patch-clamp electrode; 6 , valve system.

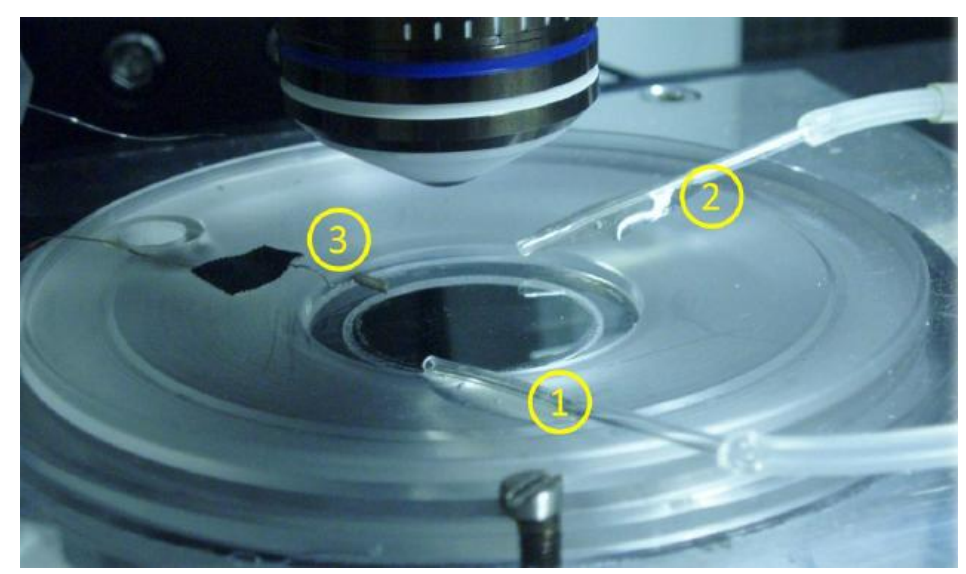

\section{Fig. 2.7 Bathing chamber}

From Biophysikalisches Praktikum (Salonikidis 2003) The picture shows the measuring chamber with solution inflow (1), solution suction (2) and electrode (3).

The specimen can be observed either through the ocular or live on the pc monitor using the IXON camera DV887DCS (ANDOR TECHNOLOGY, South Windsor, CT, USA) where the measurements are recorded. During the experiments all light is switched off and the setup is protected from remaining light using a cloth blanket all around the cage. 


\subsubsection{Experimental procedure}

For the measurements, the coverslips carrying the transfected N1E-115 cells were taken out of the cell culture dishes with a pincette and positioned into the chamber. The chamber was filled with tyrode containing the additives as indicated above. The images taken are recorded by the camera corresponding pc program AndorlQ (Andor Technology) with the three distinct images as explained above. The horizontal readout was adjusted at 5,000 $\mathrm{MHz}$ and the vertical readout at $3,400 \mathrm{MHz}$. Before FRET measurements cells were measured that express just the fluorescent dyes for calibration purpose with the same filter sets as in FRET trials. For these control measurements the cells were recorded for 120 seconds. For receptor expression analysis the filter sets were manually changed according to the respective staining. Pictures were taken with a red filter set for detection of mCherry tagged $5-\mathrm{HT}_{7}$ and a $\mathrm{QD}$ filter was used for recording of $\mathrm{QD}$ labeled $5-\mathrm{HT}_{1 \mathrm{~A}}$ receptors. After expression analysisimage-taking the picture frame has not been shifted again, so that FRET measurements were performed with cells expressing both sorts of receptors. In subsequent analysis only these cells have been evaluated that expressed both receptors. In the actual FRET measurements the fluorescence was monitored over three periods of time, $90 \mathrm{~s}$ before, $360 \mathrm{~s}$ during agonist application, $420 \mathrm{~s}$ during simultaneous application of agonist and potential antagonist (Exemplary time table and measurement see 3.2). For selection of different solutions during the experiment the afferent tubes were opened and closed manually with valves. For pertussis toxin experiments and experiments with cells expressing dominant inactive $G_{i}$ proteins the same time scale and application was used.

After data acquisition the IQ-program created a two color series. From each image one halfimage was overlapped with the other half-image. The two colors of the series represented the emission light of the two channels of the image splitter. An area of interest was defined around the cell and from the mean intensity of this area, and the background intensity was subtracted by defining another area of interest in the background. Final data analysis was performed with Matlab. 
Results

\section{Results}

\subsection{Expression analysis and receptor ratio in living cells}

The purpose of the thesis is to investigate the impact of $5-\mathrm{HT}_{1 \mathrm{~A}}-5-\mathrm{H} \mathrm{T}_{7}$ receptor coexpression on signaling with [CAMP] as preliminary endpoint. In order to be able to establish a statement about the two-receptor interaction it is essential to ensure a proportionally equal expression level of both receptor subtypes in the examined cells. Both applied expression-plasmids were of the same size and cloned into the same vector with the same promoter. Therefore it can be expected that the two receptors are expressed in equal shares when the cells are transfected with the same amount of cDNA. In order to prove that this protocol results in equal expression levels, three steps of confirmation were implemented; FACS analysis should validate the expression of the two receptors in an average batch of transfected cells, functional analysis using antagonists and optical verification in each measuring cell further verified equal expression levels. For FACS analysis N1E-cells were transfected with the same amount of cDNA encoding for the $5-\mathrm{HT}_{7}$ receptor as with cDNA encoding for the 5$\mathrm{HT}_{1 \mathrm{~A}}$ receptor. This experiment was performed by Dr. Marcus Niebert. FACS (Fluorescenceactivated cell sorting) analysis can provide information about the properties of single cells when the separately pass a laser beam in an annular fluid stream. It can therefore be used to detect cell surface components such as receptors by attaching to these specific antibodies conjugated with fluorochromes which are optimally excited at the wavelength emitted by the laser. A photomultiplier (PTM) detects the fluorescent intensity emitted by the passing cells. The intensity is proportional to the number of fluorescent markers and consequently receptors on each cell. In this case N1E cells expressing $5-\mathrm{HT}_{1 \mathrm{~A}}$ and subsequently cells expressing $5-\mathrm{HT}_{7}$ receptors were measured. The receptors were tagged with antibodies (HA for $5-\mathrm{HT}_{1 \mathrm{~A}}$ and myc for $5-\mathrm{HT}_{7}$ ) conjugated with fluorescent quantum dots (wavelength: 655 $\mathrm{nm}$ ). Since the receptors were labeled with the same fluorescent marker they were measured consecutively to avoid signal disturbance. The data was plotted in a single parameter histogram with a logarithmic scale of the fluorescent intensity on the $x$-axis and the cell count on the y-axis. Fig. 3.1 depicts that two cell populations of the same size, one expressing 5$\mathrm{HT}_{1 \mathrm{~A}}$ (red), the other one expressing $5-\mathrm{HT}_{7}$ (grey) reveal an equal fluorescent intensity pattern. The two populations show virtually no difference of cell surface labeling. Therefore, one can infer that the cells express the same amount of $5-\mathrm{HT}_{1 \mathrm{~A}}$ receptors as $5-\mathrm{HT}_{7}$ receptors when the same amount of cDNA has been transfected. The intensity peak lies at approximately $10^{4}$ and is directly related to the voltage applied to the detector in order to 
Results

amplify the signal. The voltage is usually chosen so that non fluorescent cells or particles lie within the first decade of the fluorescent scale (special thanks to Dr. Marcus Niebert).

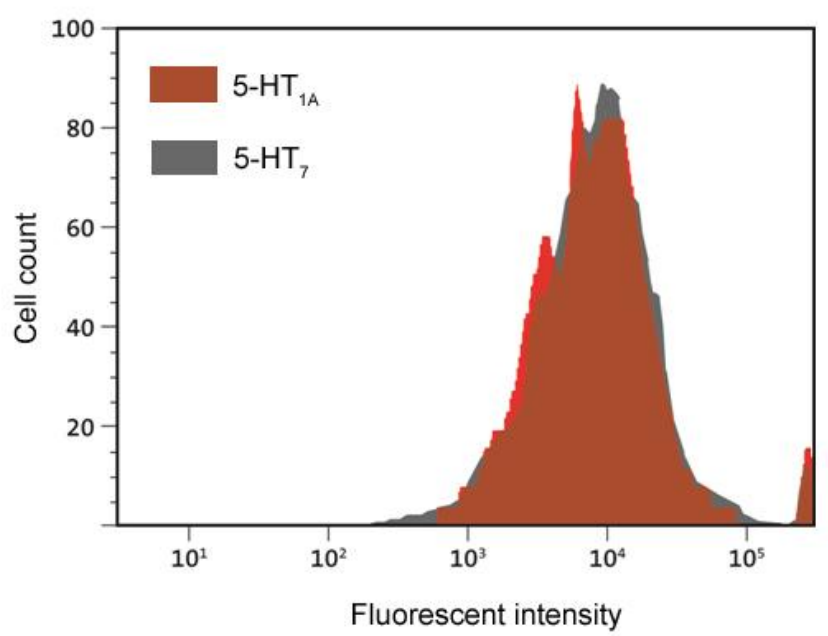

Fig. 3.1 $5-\mathrm{HT}_{1 \mathrm{~A}}$ and $5-\mathrm{HT}_{7}$ expression on N1E cells

The picture shows an overlay FACS histogram of the fluorescence patterns of two populations of N1E cells. Measurements have been conducted by Dr. Marcus Niebert. One population has been transfected with cDNA for $5-\mathrm{HT}_{1 \mathrm{~A}}$ receptors (red) and the other one has been transfected with the same amount of cDNA, coding for $5-\mathrm{HT}_{7}$ receptors (grey). The fluorescent patterns of the HA-tagged $5-\mathrm{HT}_{1 \mathrm{~A}}$ cells and the myc-tagged $5-\mathrm{HT}_{7}$ expressing cells, both marked with fluorescent quantum dots (Invitrogen, $655 \mathrm{~nm}$ ), show virtually no difference. Therefore an equal expression level of the two serotonin receptors can be inferred. The intensity peak lies at $10^{4}$ and is directly correlated to the voltage applied to the recording PTM detector.

The FACS data already gave an estimation about the expression level of an averaged batch of cells. However, the expression ratio in single cells can vary significantly. In order to select single cells with appropriate receptor ratio in the actual measurements, optical verification of the expression was performed in each experiment and for every measuring cell.

To distinguish the two receptor subtypes on a single cell level under the microscope, $5-\mathrm{HT}_{7}$ receptors were tagged with the $\mathrm{N}$-terminal fluorescent protein mCherry, whereas $5-\mathrm{HT}_{1 \mathrm{~A}}$ receptors were labeled with quantum dots (QD) recognizing antibodies against HA tags of recombinantly expressed $5-\mathrm{HT}_{1 \mathrm{~A}}$ receptors. The combination of one transfected marker (mCherry) and one antibody conjugated fluorochrome in the form of quantum dots was 
chosen for two reasons. The first reason was to avoid transfection of too much alien cDNA and therefore potentially alter protein expression rates and the second reason was to coordinate the multiple fluorochromes (mCeruean, mCitrine, mCherry, QD) without unintended overlap of their spectra (see 2.1.5). Control experiments were carried out to assure that neither $\mathrm{N}$-terminal fluorescent tags nor QD labeling affected $5-\mathrm{HT}$ signaling. These controls revealed that mCherry tagging of $5-\mathrm{HT}_{1 \mathrm{~A}}$ receptors resulted in blunted signals, whereas $5-\mathrm{HT}_{7}$ receptors were not affected by mCherry tags (Fig. 3.8). The diagram shows that $\mathrm{QD}$ labeling in turn did not impair $5-\mathrm{HT}_{1 \mathrm{~A}}$ receptor signaling. For subsequent experiments only these cells should be selected and analyzed which expressed both receptors in equal amounts. Therefore two fluorescence emission pictures of each sample were taken prior to all 5- $\mathrm{HT}$ measurements. One picture with a red light filter at $580 \mathrm{~nm}$ excitation to indentify mCherry tagged $5-\mathrm{HT}_{7}$ receptors and a second picture with a QD filter set at $655 \mathrm{~nm}$ to detect the $\mathrm{QD}$ labeled 5- $\mathrm{HT}_{1 \mathrm{~A}}$ receptors (see also 2.1.5). Fig. 3.2 shows how measuring cells have been selected. Only if a certain cell was clearly visible in both channels and therefore expressed both receptors, it was chosen for subsequent analysis. 

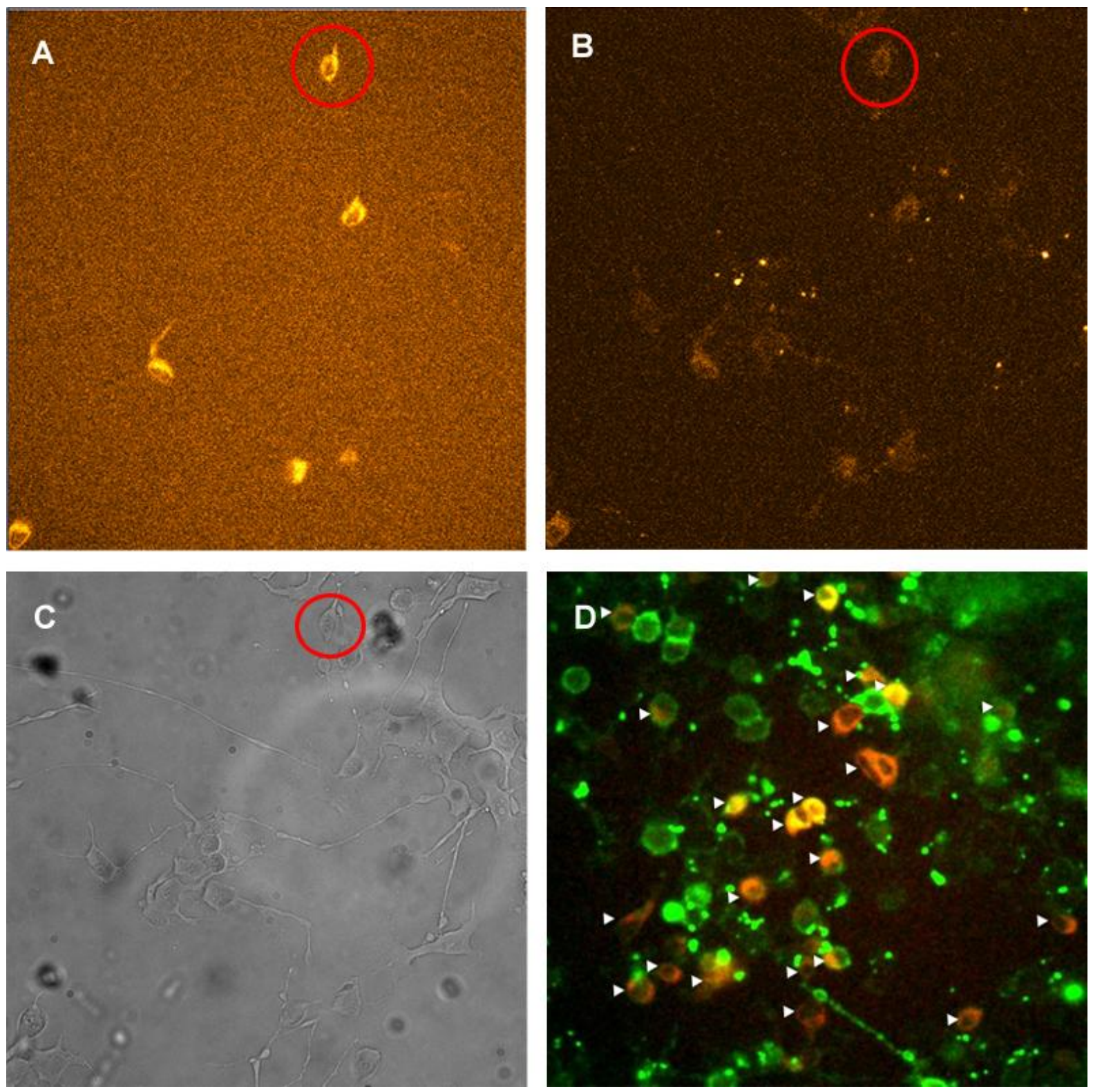

Fig. 3.2 $5-\mathrm{HT}_{1 \mathrm{~A}^{-}}-5-\mathrm{HT}_{7}$ expression analysis on measuring cells

A-C, The images show the same field of view and the same batch of N1E-cells at different excitation wavelengths and different emission filter sets. The population of cells coexpressed $5-\mathrm{HT}_{1 \mathrm{~A}}$ and $5-\mathrm{HT}_{7}$ receptors which are marked with $Q D$ and mCherry fluorochromes, respectively. A: red light filter, showing the mCherry fluorescence of $5-\mathrm{HT}_{7}$ receptors at $580 \mathrm{~nm}$ excitation, $\mathrm{B}$ : QD filter, showing quantum dots attached to $5-\mathrm{HT}_{1 \mathrm{~A}}$ receptors at $655 \mathrm{~nm}$ excitation, C: transmitted light, no filter. Red circles indicate a coexpressing cell which was subsequently taken for measurements.

D, Overlap of two pictures of the same $5-\mathrm{HT}_{1 \mathrm{~A}^{-}} 5-\mathrm{HT}_{7}$ coexpressing cells at different excitation and emission filters. The image is derived from one picture showing the distribution of QD labeled $5-\mathrm{HT}_{1 \mathrm{~A}}$ receptors in green color and a second picture displaying the presence of mCherry tagged $5-\mathrm{HT}_{7}$ receptors in red color. The cells were excited in two consecutive rounds with distinct filter sets as 
Results

indicated in A-C. White arrows refer to cells, which expressed both receptors and were taken for analysis.

This analysis is not quantitative but it is able to prove coexpression in single cells. In addition to this optical confirmation, functional behavior strongly suggests the significant presence of both receptors in single cells, as demonstrated in Fig. 3.3. The figure depicts the fluorescence intensity curves of the CEPAC* sensor in $5-\mathrm{HT}_{1 \mathrm{~A}}-5-\mathrm{HT}_{7}$ coexpressing cells.

In this measurement 5-HT receptors were activated with $1 \mu \mathrm{M}$ serotonin and subsequently blocked with the $5-\mathrm{HT}_{7}$ specific antagonist SB-269970 hydrochloride (SB) (Hagan et al. 2000). In similar experiments the receptor activation was significantly blocked with WAY 100635 (WAY), a specific 5- $\mathrm{HT}_{1 \mathrm{~A}}$ receptor antagonist (Chemel et al. 2006) (all data shown below). Both antagonists were applied at a concentration of $1 \mu \mathrm{M}$. Control experiments with only $5-\mathrm{HT}_{7}$ expressing and only $5-\mathrm{HT}_{1 \mathrm{~A}}$ expressing cells excluded that antagonists at this concentration had a comparable influence on the nonspecific contrary receptor (Fig. 3.7). The two antagonists were therefore both able to inhibit receptor activation of $5-\mathrm{HT}_{1 \mathrm{~A}}$ and 5$\mathrm{HT}_{7}$ coexpressing cells, suggesting that either of the receptors were expressed in a functional effective quantity. This is under the assumption that coexpression does not change receptor function or antagonist specificity. Nevertheless, the fact, that coexpressing cells show altered activation- and inhibition patterns compared to single receptor expressing cells, is by itself a proof for the presence of both receptor subtypes in a functional significant quantity (see discussion). 

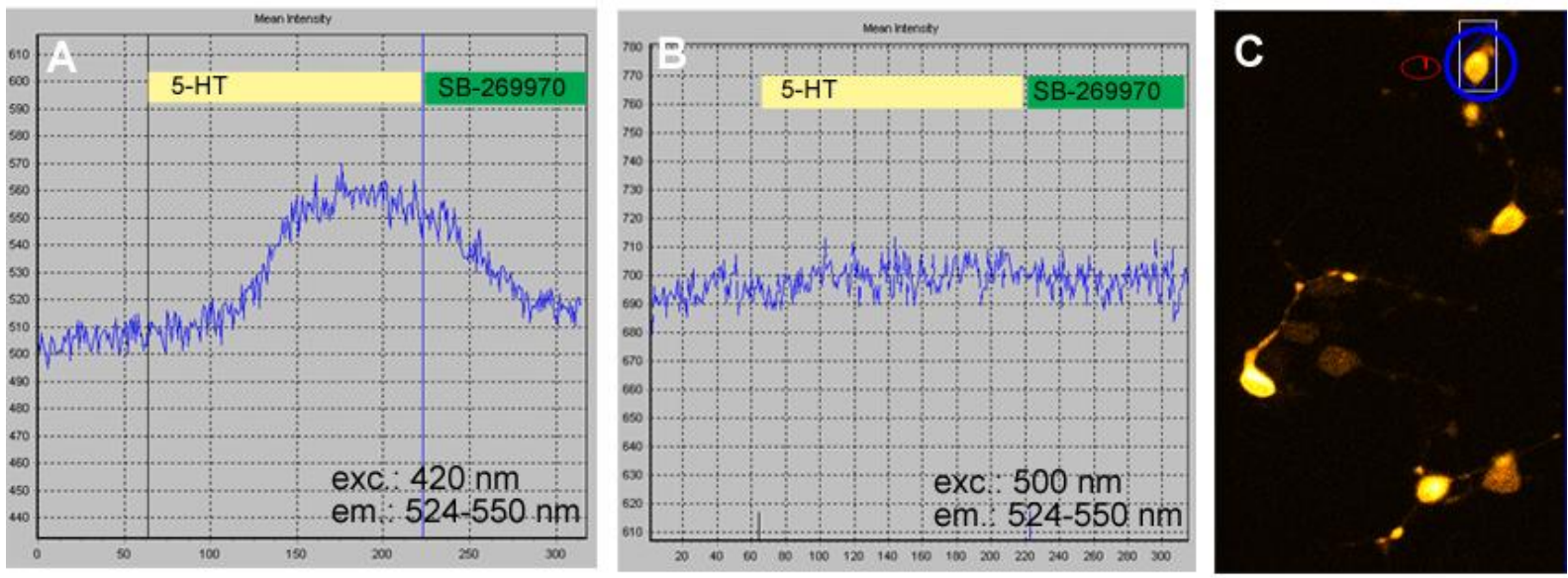

\section{Fig. 3.3 Functional coexpression verification}

Intensity curves of the CEPAC*-sensor linked fluorophores mCitrine and mCerulean over time in the $\mathrm{IQ}$ acquisition program. A, mCitrine + mCerulean emission at $420 \mathrm{~nm}$ excitation; $\mathbf{B}$, mCitrine emission at $500 \mathrm{~nm}$ excitation; C, fluorescent coexpressing cells during exciation, blue circle indicates measuring cell (as seen in Fig. 3.2). Picture A shows the intensity at donor excitation whereas picture $B$ follows the intensity at direct acceptor excitation and serves as control. Again, excitation at acceptor wavelength does not result in FRET. Upon agonist application (yellow bar) a change in acceptor emission intensity becomes apparent in picture A. This implies a change of FRET and consequently a change of [CAMP]. Direct acceptor excitation (B) does not show this change. Green bar, SB-269970 inhibition.

\section{2 cAMP concentration measurements}

The FRET-based fluorescence measurements were performed (as described in 2.4.2) on N1E-115 neuroblastoma cells, co-transfected with plasmids encoding for CEPAC* and either for serotonin receptor subtype $5 \mathrm{HT}_{7}$ or $5 \mathrm{HT}_{1 \mathrm{~A}}$, as well as on cells coexpressing both receptors. Cells in subsequent experiments were incubated in $100 \mathrm{nM}$ Forskolin before (about $10 \mathrm{~min}$ ) and also during measurements so as to approximate an average cAMP level, which allows the two-receptor model both, to increase and to decrease [cAMP]. $100 \mathrm{nM}$ is according to the $\mathrm{EC}_{50}$ value $(98 \pm 45 \mathrm{nM})$ of Forskolin. This value was determined in previous 
Results

experiments ( $\mathrm{n}=86$ cells) for our cell model, using $E f_{D A} / Y$ as a response signal by my colleagues G. Bao and P. Salonikidis. In each measurement the fluorescence was monitored over three periods of time, $90 \mathrm{~s}$ before, $360 \mathrm{~s}$ during agonist application, $420 \mathrm{~s}$ during simultaneous application of agonist and respective antagonist. Fig. 3.4 illustrates exemplary time lapses of $E f_{D A} / V$ recordings of cells coexpressing $5-\mathrm{HT}_{1 \mathrm{~A}}$ and $5-\mathrm{HT}_{7}$ receptors.
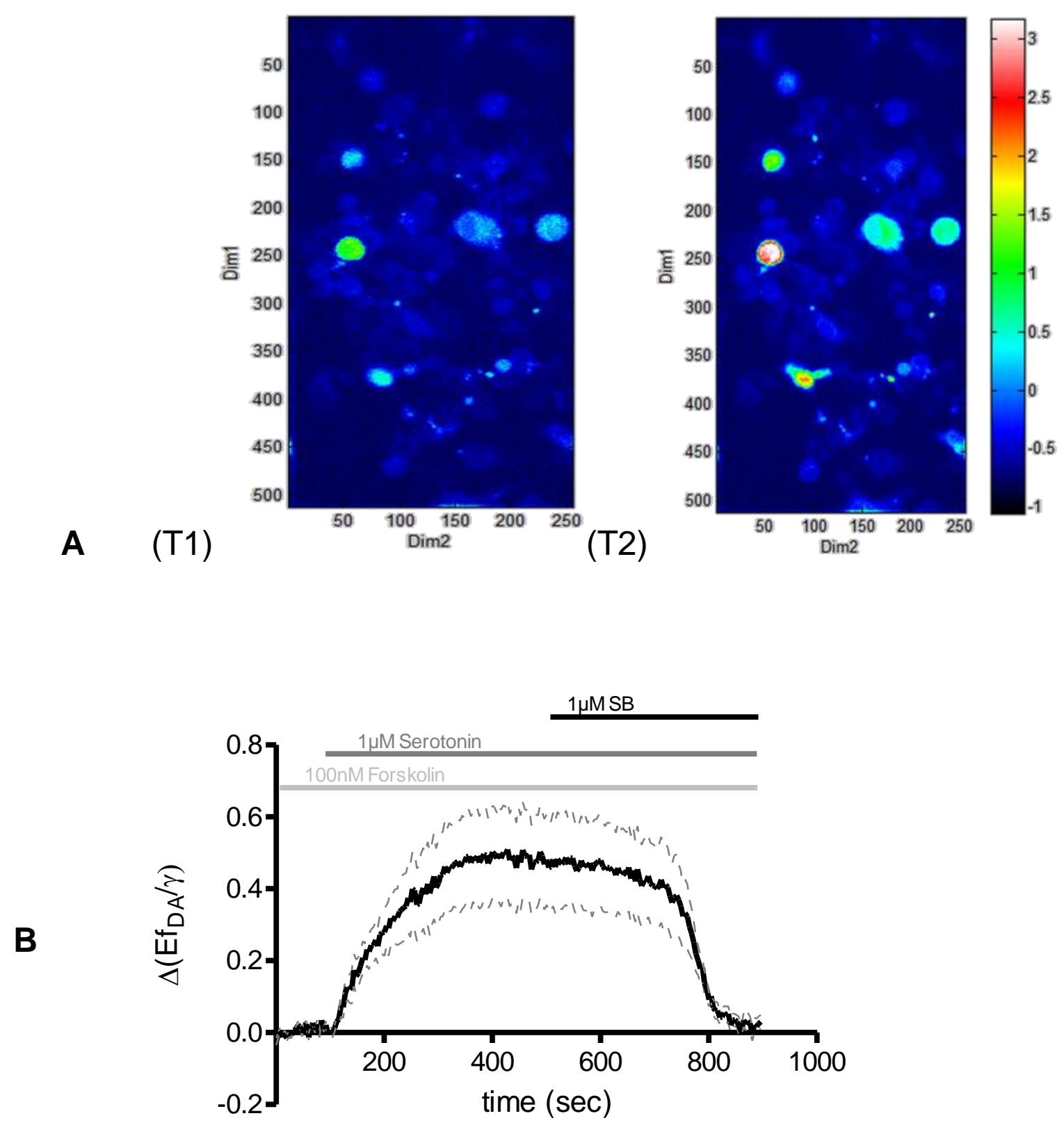

Fig. 3.4 [CAMP] progression upon serotonin application and inhibition

N1E cells were co-transfected with CEPAC ${ }^{*}, 5-\mathrm{HT}_{1 \mathrm{~A}}$ and $5-\mathrm{HT}_{7}$ receptors. Cells were pre-incubated in $100 \mathrm{nM}$ Forskolin $\left(\mathrm{EC}_{50}\right.$ value of adenylate cyclase-activation). Application of $1 \mu \mathrm{M}$ serotonin led to increase of FRET intensity (EfDA/Y) which corresponds to a cAMP decrease. Application of the $5-\mathrm{HT}_{7}$ 
Results

specific antagonist SB-269970 inhibits the effect. A shows two $\mathrm{Ef}_{\mathrm{DA}} / \mathrm{V}$-pictures of cells at different time points, including 12 regions of interest per picture (white). AT1 represents a registration before serotonin application and AT2 during serotonin application. The $\mathrm{Ef}_{\mathrm{DA}} / \mathrm{Y}$ values are translated into a color code. $\mathbf{B}$, the displayed $\Delta\left(E f_{D A} / Y\right)$ time lapse (black line) consist of averaged values of 12 regions of interests $(\mathrm{ROI})$. The error SE is displayed as a gray dashed line.

\subsubsection{Kinetic measurements, comparison of stimulation - response intervals}

Fig. 3.5 reveals the delays between effector application and $E f_{D A} / V$ changes depending on the volume of the bathing chamber and the fluorescence sensor.

Picture A shows the intervals (in sec) between agonist application and detectable effect of the different receptors in a setup with a solution chamber of about $1.5 \mathrm{ml}$. Depending on the sensor, the times differed from $37 \pm 7 \mathrm{~s}$ with the former sensor (EPAC) (see 3.4) and $37 \pm 1 \mathrm{~s}$ with the new sensor $\left(\mathrm{CEPAC}^{*}\right.$ ) for the $5-\mathrm{HT}_{7}$ receptor to $62 \pm 11 \mathrm{~s}$ (EPAC) and $16 \pm 1 \mathrm{~s}$ $\left(\right.$ CEPAC $\left.^{*}\right)$ for $5-\mathrm{HT}_{1 \mathrm{~A}}$. In this case the new sensor CEPAC ${ }^{*}$ appeared more reliable in terms of the reproducibility of the intervals. However, there was the paradoxical situation that depending on the sensor $5-\mathrm{HT}_{1 \mathrm{~A}}$ exhibited longer or shorter intervals than $5-\mathrm{HT}_{7}$. Therefore the bath chamber was optimized and reduced to a total volume of about $500 \mu \mathrm{l}$ and only the new sensor has been utilized in subsequent experiments. Fig. 3.5 B consequently shows the intervals between agonist application and $E f_{D A} / Y$ change in the smaller chamber with the CEPAC* $^{*}$ sensor. The times averaged $9 \pm 1 \mathrm{~s}$ for $5-\mathrm{HT}_{7}$ and $9.5 \pm 1 \mathrm{~s}$ for $5-\mathrm{HT}_{1 \mathrm{~A}}$ and displayed no detectable difference among the used chemicals. These delays can be accounted for by the solution exchange speed in the bath chamber. 
Results

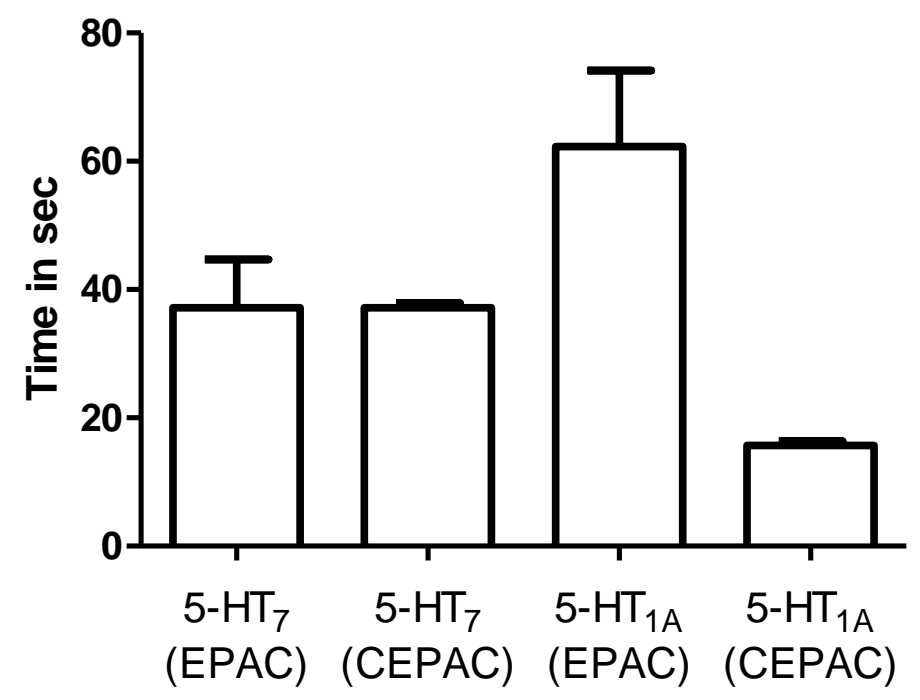

A

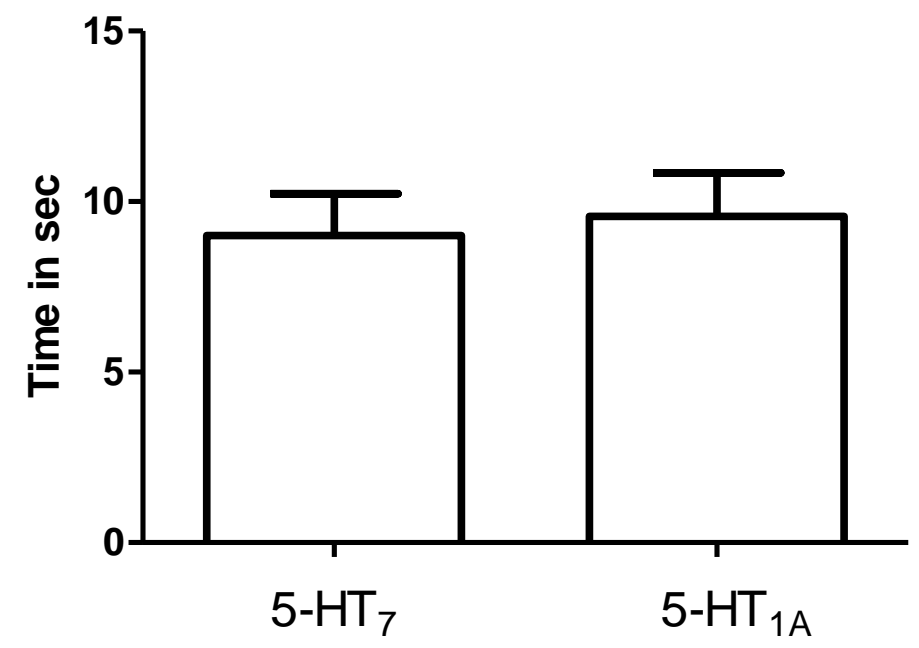

B

Fig. 3.5 Kinetics of [CAMP] changes depending on the experimental setup and sensor

The figure reveals the intervals between agonist application and $E f_{D A} / Y$ change in $5-\mathrm{HT}$ experiments as indicated in Fig. 3.4. (error bars, SE) A, bigger bath chamber $(1.5 \mathrm{ml})$ for the former sensor EPAC and the new sensor CEPAC* (10 ROls each); B, optimized chamber $(500 \mu l)$ with CPEAC* only (10 ROIs each).

The following block diagrams in 3.2.2 were all derived from average $E f_{D A} / V$ values at stable state in time courses of collective measurements. 
Results

\subsubsection{5-HT activation of $5-\mathrm{HT}_{7}$ and $5-\mathrm{HT}_{1 \mathrm{~A}}$ coexpressing cells}

Prior to 5-HT application the intracellular cAMP concentrations were analyzed. This step was important to exclude that up or down regulation of $A C$ by basal receptor activity would regulate the cAMP level beyond the dynamic range of the biosensor before 5-HT application. Therefore, the biosensor was calibrated in order to assign quantitative cAMP concentration values to the measured $E f_{D A} / Y$ values as described previously (Salonikidis et al. 2008). In all cases the CAMP concentrations were within the dynamic range of the biosensor.

Fig. 3.6 reveals the $E f_{D A} / Y$ changes upon agonist application for $5-\mathrm{HT}_{7}$ and $5-\mathrm{HT}_{1 \mathrm{~A}}$ receptors separately and coexpressed in the same cells. First, $5-\mathrm{HT}_{7}$ expressing cells were stimulated with serotonin at a concentration of $1 \mu \mathrm{M}$. Fig 3.6 shows that $5-\mathrm{HT}$ application led to a decrease of $E f_{D A} / Y$ of about $0.35 \pm 0.03\left(E_{50}\right.$ value derived from Andressen et al. 2006) in cells with this receptor type. A decrease of $E f_{D A} / V$ corresponds to an increase of intracellular [CAMP], which was expected since the $5-\mathrm{HT}_{7}$ receptor is described to enhance AC activity via $\mathrm{G}_{\mathrm{as}}$. Specific $5-\mathrm{HT}_{7}$ receptor blockade with $1 \mu \mathrm{M}$ SB inhibited the agonist induced rise about $70 \pm 6 \%$ (Fig. 3.7 A). That correlates to an $E f_{D A} / y$ increase of about $0.18 \pm 0.06$. SB in this concentration was hardly able to block receptor activation of cells expressing only the $5-\mathrm{HT}_{1 \mathrm{~A}}$ receptor in subsequent measurements (3 $\pm 1 \%$; $\Delta E f_{D A} / Y 0.03 \pm 0.01$ ) (Fig. $3.7 \mathrm{~B}$ ). These values represent the blocking abilities of $\mathrm{SB}$ for the respective receptors and correspond to $\mathrm{SB}$ receptor affinities in literature: $\mathrm{pK}_{1} 8.9 \pm 0.1$ for $5-\mathrm{HT}_{7}$ and $<6.0$ for $5-\mathrm{HT}_{1 \mathrm{~A}}$ (Hagan et al. 2000).

Afterwards, 5- $\mathrm{HT}_{1 \mathrm{~A}}$ expressing cells were stimulated with $1 \mu \mathrm{M} 5-\mathrm{HT}$. Fig. 3.6 shows an increase of the biosensor signal $E f_{D A} / Y$ of about $0.42 \pm 0.02$ upon $5-\mathrm{HT}$ application $\left(E_{50}\right.$ value derived from Sharif et al. 2004). This increase corresponds to a decrease of [CAMP] and was expected since the $5-\mathrm{HT}_{1 \mathrm{~A}}$ receptor is described to inhibit $A C$ activity via $\mathrm{G}_{\mathrm{ai}}$. This effect was blocked to $77 \pm 7 \%$ by $1 \mu \mathrm{M}$ specific $5-\mathrm{HT}_{1 \mathrm{~A}}$ receptor antagonist WAY (Fig. $3.7 \mathrm{~B}$ ). In contrast single $5-\mathrm{HT}_{7}$ receptor activation in absence of $5-\mathrm{HT}_{1 \mathrm{~A}}$ was only blocked about 25 $\pm 14 \%$ by the same concentration of WAY ( $E f_{D A} / V$ change of $\left.0.042 \pm 0.03\right)$ (Fig. $\left.3.7 \mathrm{~A}\right)$. These blocking values are also in accordance to literature WAY $\mathrm{pK}_{\mathrm{I}}$ values of 8.66 and $<5.0$ for $5-\mathrm{HT}_{1 \mathrm{~A}}$ and $5-\mathrm{HT}_{7}$, respectively (Chemel et al. 2006).

Eventually, $5-\mathrm{HT}_{7}$ - and $5-\mathrm{HT}_{1 \mathrm{~A}}$ coexpressing cells were stimulated with $1 \mu \mathrm{M}$ serotonin. This activation led to an increase of $E f_{D A} / Y$ about $0.46 \pm 0.04$ (Fig. 3.6) which correlates to a decrease in [cAMP]. This is virtually the same effect as in cells which express only $5-\mathrm{HT}_{1 \mathrm{~A}}$. It is striking, that the inhibitory influence of the $5-\mathrm{HT}_{1 \mathrm{~A}}$ receptor on $\mathrm{AC}$ was not compensated by 
Results

$5-\mathrm{HT}_{7}$ but appeared clearly dominant. It is also noteworthy, that $5-\mathrm{HT}_{1 \mathrm{~A}}$ and $5-\mathrm{HT}_{7}$ receptor coexpression seemed to cause a slightly stronger change in FRET and displayed enhanced inhibition (see below) compared to cells which express only one receptor subtype. An unpaired $\mathrm{t}$ test with Welch's correction revealed that the $E f_{D A} / V$ change in $5-\mathrm{HT}_{7}$ - only expressing cells differs significantly from the change in coexpressing cells with a $p$-value of 0.035 in a $95 \%$ confidence interval, whereas the $E f_{D A} / y$ values of $5-\mathrm{HT}_{1 \mathrm{~A}}$ - only expressing cells and coexpressing cells turned out to not differ significantly.

\section{Excitation}

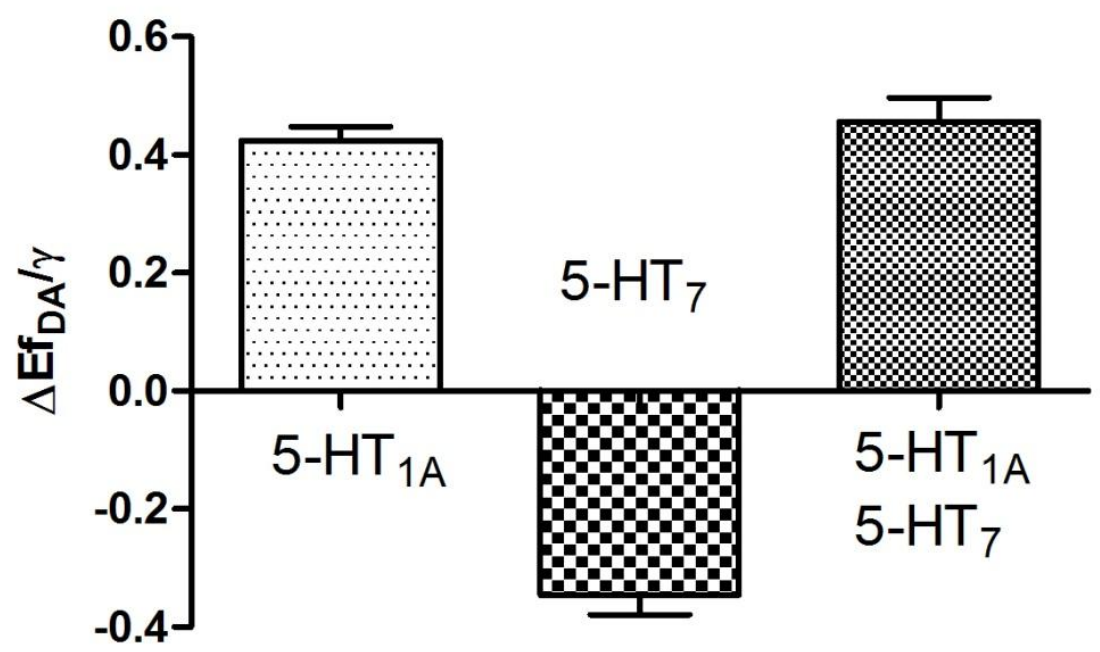

Fig. 3.6 Changes of cAMP concentrations upon 5-HT activation

The figure depicts the changes of $E f_{D A} / \gamma$ after application of $1 \mu \mathrm{M}$ serotonin on cells that express either $5-\mathrm{HT}_{1 \mathrm{~A}}, 5-\mathrm{HT}_{7}$ or both receptors at the same time. Experimental setup as described in 3.2. Error bars, SE. $5-\mathrm{HT}_{1 \mathrm{~A}}$ expressing cells exhibited a rise about $0.42 \pm 0.02(\mathrm{n}=126 \mathrm{cells} / \mathrm{ROIs}), 5-\mathrm{HT}_{7}$ expressing cells showed a descent about $0.35 \pm 0.03$ ( $n=213$ cells/ROls) and coexpressing cells exhibited an increase about $0.46 \pm 0.04$ ( $\mathrm{n}=236 \mathrm{cells} / \mathrm{ROIs}$ ). $E f_{D A} / V$ reaction is inversely proportional to [cAMP] development. 


\section{5-HT7}

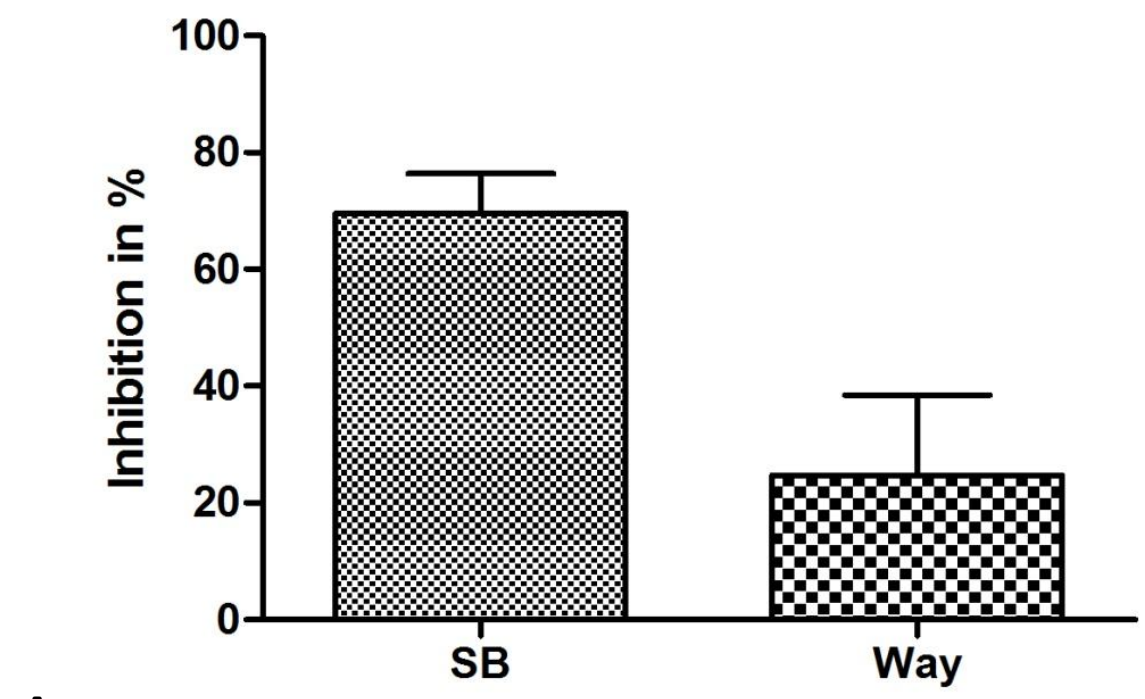

A
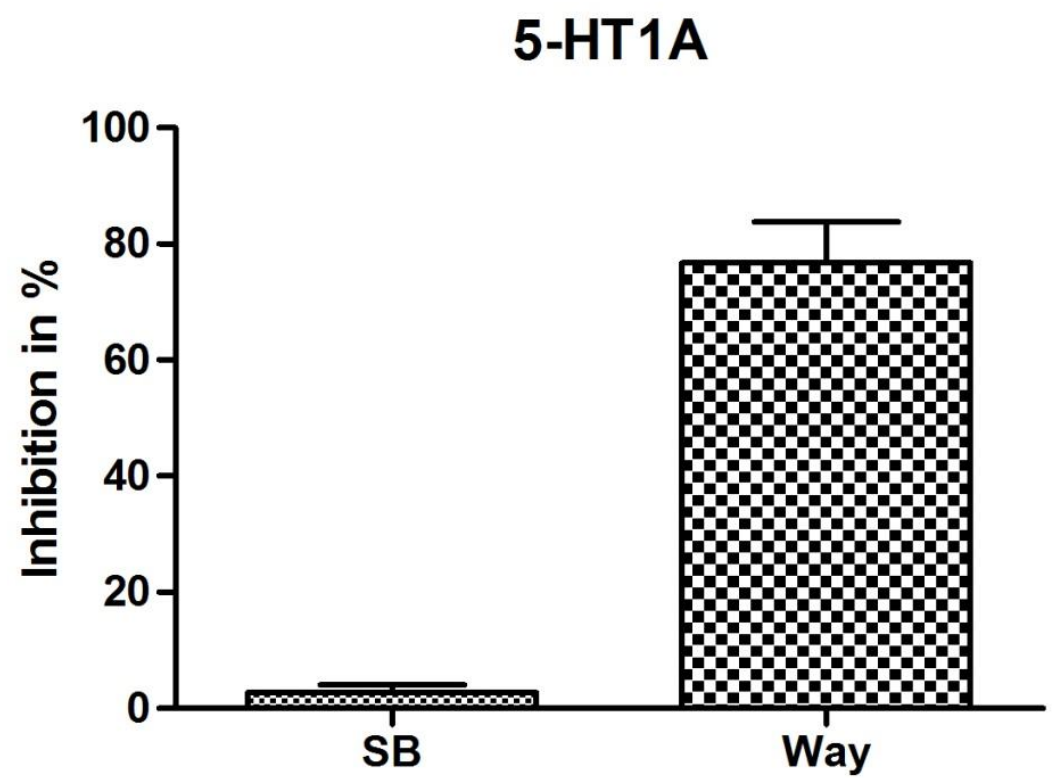

B

Fig. 3.7 Specific blockade of previous 5-HT activation in single receptor expressing cells

Blocking abilities of the $5-\mathrm{HT}_{7}$ specific antagonist $\mathrm{SB}$ and the $5-\mathrm{HT}_{1 \mathrm{~A}}$ specific antagonist WAY after previous serotonin activation, in percent. Experimental setup as described in 3.2. Error bars, SE. A, 5$\mathrm{HT}_{7}$ expressing cells were blocked by SB to $70 \pm 6 \%$ ( $\mathrm{n}=57$ cells/ROIs) and by WAY to $25 \pm 14 \%$ ( $\mathrm{n}$ $=21 \mathrm{cells} / \mathrm{ROIs}$ ); $\mathbf{B}, 5-\mathrm{HT}_{1 \mathrm{~A}}$ expressing cells were blocked by SB to $3 \pm 1 \%$ ( $\mathrm{n}=52$ cells/ROIs) and by WAY to $77 \pm 7 \%$ ( $n=53$ cells $/$ ROIs $)$. 


\subsubsection{How receptor labeling affects signaling}

Fig. 3.8 A and B reveal control experiments in single receptor expressing cells. In order to identify $5-\mathrm{HT}_{1 \mathrm{~A}}$ and $5-\mathrm{HT}_{7}$ on the measuring cells, the receptors have been labeled as described previously in 3.1. Ideally, receptor labeling should not interfere with the actual FRET measurements. Fig. 3.8 A shows the $E f_{D A} / V$ changes upon application of $1 \mu \mathrm{M}$ serotonin in $5-\mathrm{HT}_{1 \mathrm{~A}}$ expressing cells, tagged with the transfected fluorophore mCherry or the antibody conjugated quantum dots compared to unlabeled controls. The mCherry tagged samples delivered weaker results $\left(E f_{D A} / \gamma\right.$ change: $\left.0.28 \pm 0.03\right)$ than QD labeled cells $(0.4 \pm$ 0.02) (controls: $0.41 \pm 0.03$ ). FRET results of $5-\mathrm{HT}_{7}$ expressing cells by contrast were not significantly affected by mCherry tags. (Fig. $3.8 \mathrm{~B}$ ) Thus, it became apparent that $5-\mathrm{HT}_{7}$ receptors labeled with mCherry and $5-\mathrm{HT}_{1 \mathrm{~A}}$ receptors tagged with QDs were the best combination for further coexpression experiments.

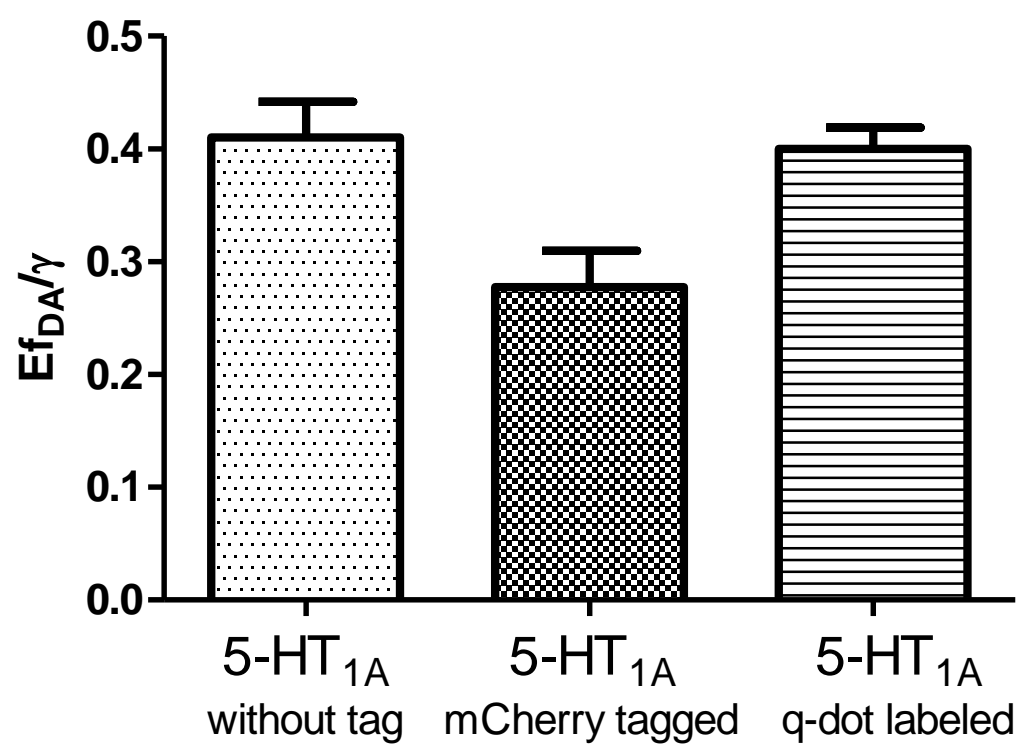

A 


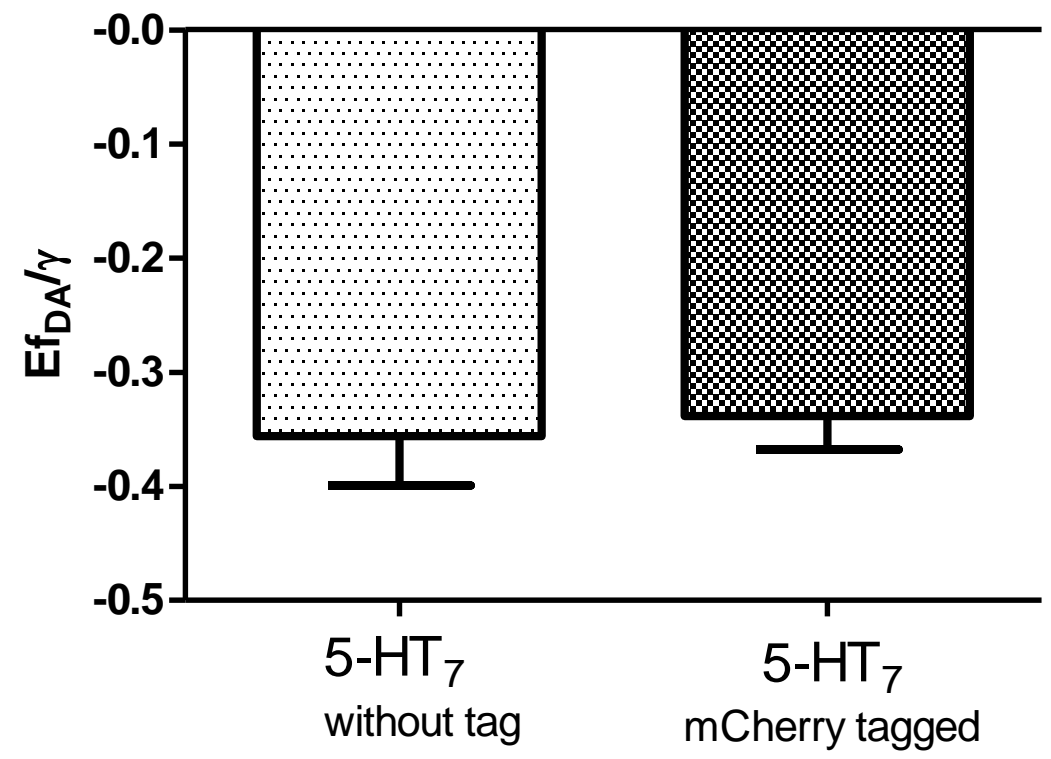

B

\section{Fig. 3.8 Control measurements: How receptor labeling affects FRET signals}

$E f_{D A} / Y$ changes upon stimulation with $1 \mu \mathrm{M} 5-\mathrm{HT}$. Experimental setup as described in 3.2. Error bars, SE. $E f_{D A} / Y$ reaction is inversely proportional to [CAMP] development. A, 5- $\mathrm{HT}_{1 \mathrm{~A}}$ expressing cells without tag $(0.41 \pm 0.03, n=27$ cells/ROIs $)$, mCherry tag $(0.28 \pm 0.03, n=21)$ or QD labeling $(0.4 \pm 0.02, n=$ 8). QD labeling yielded stronger results than mCherry tagged cells. $\mathbf{B}, 5-\mathrm{HT}_{7}$ expressing cells were not significantly influenced by mCherry tags $(-0.34 \pm 0.03, n=15$ cells/ROls; controls: $-0.36 \pm 0.04, n=$ 74)

\subsubsection{Functional interaction between $5-\mathrm{HT}_{1 \mathrm{~A}}$ and $5-\mathrm{HT}_{7}$ receptors}

Since GPCRs generally may form homo- or hetero-oligomers (Maggio et al. 2005, Gurevich and Gurevich 2008, Woehler and Ponimaskin 2009, Renner et al. 2012) which sometimes results in altered signaling properties, we were interested in the functional interaction between the two contrary acting receptors $5-\mathrm{HT}_{1 \mathrm{~A}}$ and $5-\mathrm{HT}_{7}$ when they are expressed in the same cells. The goal was to characterize the functional state of a putative $5-\mathrm{HT}_{1 \mathrm{~A}}-5-\mathrm{HT}_{7}$ receptor hetero-oligomer. Therefore, the functionality of the agonist and antagonist bindingsites of both receptors should be investigated in coexpressing cells. Stimulation of these cells with $1 \mu \mathrm{M} 5-\mathrm{HT}$ increased $E f_{D A} / Y$ about $0.46 \pm 0.04$ (Fig. 3.6). In the following, this rise was blocked with $1 \mu \mathrm{M}$ of the $5-\mathrm{HT}_{1 \mathrm{~A}}$ receptor specific antagonist WAY to $92 \pm 7 \%$ (Fig. 3.9), suggesting that the $5-\mathrm{HT}_{1 \mathrm{~A}}$ receptor binding-sites are functional. Application of $1 \mu \mathrm{M} 5-\mathrm{HT}_{7}$ 
receptor specific antagonist $S B$ also inhibited the previous $E f_{D A} / y$ increase about $75 \pm 4 \%$. The response to SB indicates accessible and functional $5-\mathrm{HT}_{7}$ receptor binding-sites. It is again notable, that in coexpressing cells $1 \mu \mathrm{M}$ SB exhibits even stronger blocking abilities $(\Delta 5.55 \%)$ on $5-\mathrm{HT}$ stimulated cAMP production, than in cells expressing only $5-\mathrm{HT}_{7}$ receptors.

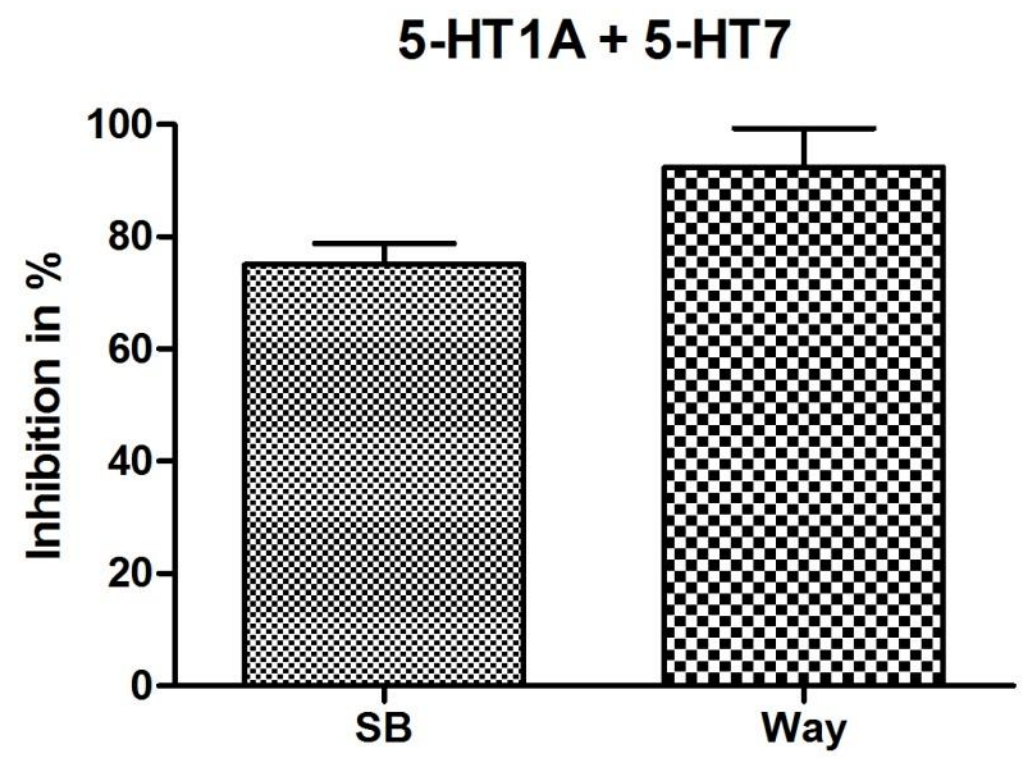

Fig. 3.9 Specific inhibition of serotonin activation in $5-\mathrm{HT}_{1 \mathrm{~A}}-5-\mathrm{HT}_{7}$ coexpressing cells

Blocking of previously 5-HT - induced $E f_{D A} / V$ rise in coexpressing cells with the $5-\mathrm{HT}_{7}$ specific antagonist $\mathrm{SB}$ and the $5-\mathrm{HT}_{1 \mathrm{~A}}$ specific WAY in percent. Experimental setup as described in 3.2. Error bars, SE. SB inhibits the rise about $75 \pm 4 \%(n=114$ cells/ROls) and Way even blocks the effect about $92 \pm 7 \%(n=27)$.

In the coexpression experiments seen so far, the $5-\mathrm{HT}_{1 \mathrm{~A}}$ pathway appeared dominant and it was possible to block this effect with the $5-\mathrm{HT}_{7}$ specific antagonist SB. Hereinafter, coexpressing cells were stimulated with the $5-\mathrm{HT}_{7}$ specific agonist AS19 to see if specific 5$\mathrm{HT}_{7}$ activation is able to evoke the same results. AS19 displays high affinity for $5-\mathrm{HT}_{7}$ and only moderate affinity for $5-\mathrm{HT}_{1 \mathrm{~A}}$ receptors (Bosker et al. 2009). So as not to coactivate 5$\mathrm{HT}_{1 \mathrm{~A}}$ receptors, AS19 was applied at a concentration of $100 \mathrm{nM}$. Fig. 3.10 A reveals that AS19 in this low concentration had virtually no effect on $5-\mathrm{HT}_{1 \mathrm{~A}}$ - only expressing cells $\left(E f_{D A} / Y\right.$ change: $\left.0.04 \pm 0.04\right)$ and a very moderate effect on $5-\mathrm{HT}_{7}-$ only expressing cells 
Results

$(-0.13 \pm 0.04)$. In coexpressing cells instead, AS19 induced a strong response. $100 \mathrm{nM}$ AS19 led to a $5-\mathrm{HT}_{1 \mathrm{~A}}$ - like [CAMP] decrease. The $E f_{D A} / \gamma$ value was increased about $0.45 \pm 0.06$, suggesting accessible and functional $5-\mathrm{HT}_{7}$ receptor binding-sites. A boost of the signal due to potential hetero-oligomerization is discussed in 4.1.1 Simultaneous application of specific antagonists in order to intensify the agonist specificity would disturb the interaction of $5-\mathrm{HT}_{1 \mathrm{~A}}$ and $5-\mathrm{HT}_{7}$ in an uncontrolled way. Therefore, the antagonist was applied separately, using the same protocol as described in 3.2. $1 \mu \mathrm{M} 5-\mathrm{HT}_{7}$ specific SB subsequently blocked the $E f_{D A} / Y$ rise about $90 \pm 7 \%$ in coexpressing cells. (Fig. $3.10 \mathrm{~B}$ ) In $5-\mathrm{HT}_{7}$ - only cells, the inhibition was only about $22 \pm 5 \%$. The weak blocking ability in $5-\mathrm{HT}_{7}-$ only expressing cells might be due to an overall weak response at this very low agonist concentration. However, even if only very few receptors are occupied with AS19, receptor binding might be very strong and hard to block after all.

AS 19 excitation

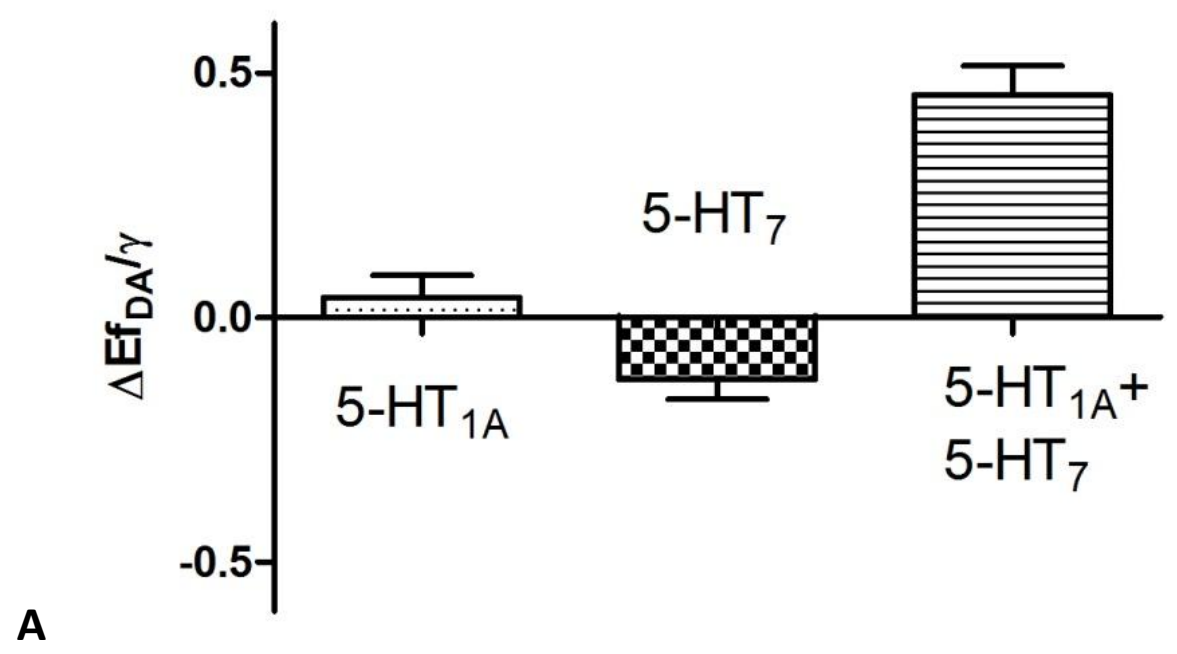




\section{SB inhibition of AS19 stimulation}

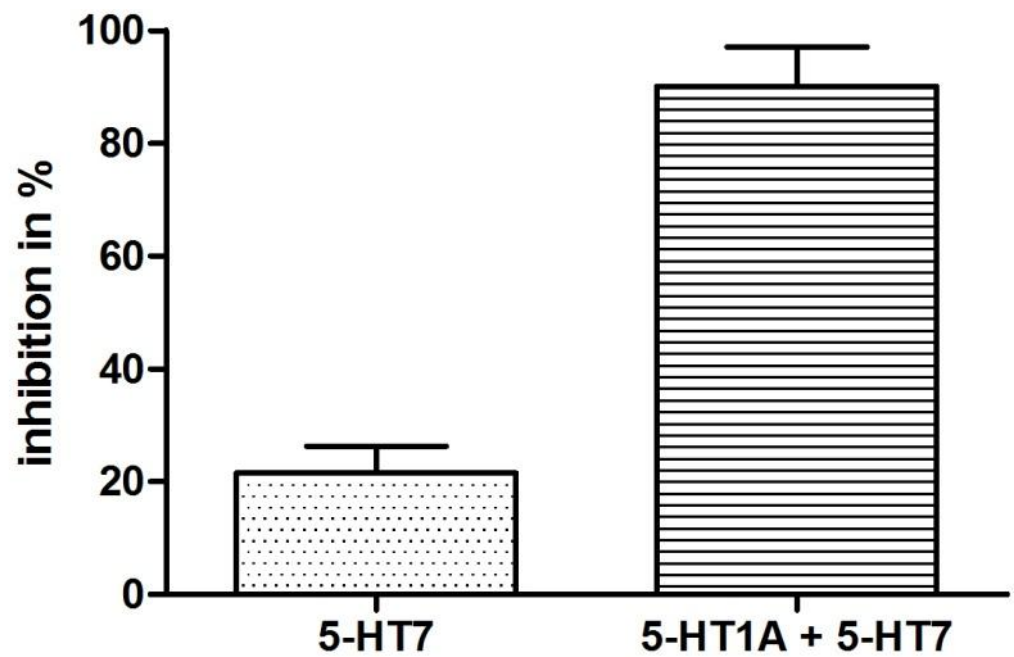

B

Fig. 3.10 Specific 5- $\mathrm{HT}_{7}$ stimulation and subsequent inhibition in coexpressing cells

A, $E f_{D A} / Y$ changes after application of $100 \mathrm{nM} 5-\mathrm{HT}_{7}$ specific AS19 on cells that express either $5-\mathrm{HT}_{1 \mathrm{~A}}$, 5- $\mathrm{HT}_{7}$ or both receptors at the same time. Experimental setup as described in 3.2. Error bars, SE. 5$\mathrm{HT}_{1 \mathrm{~A}}$ expressing cells hardly showed an effect $(0.04 \pm 0.04, \mathrm{n}=11$ cells/ROls $), 5-\mathrm{HT}_{7}$ expressing cells showed a moderate response $(-0.13 \pm 0.04, n=15$ cells/ROls $)$ and coexpressing cells exhibited an increase about $0.45 \pm 0.06$ ( $\mathrm{n}=39$ cells/ROls). $E f_{D A} / Y$ reaction is inversely proportional to [cAMP] development. B, Inhibition of the AS19 induced effect with $5-\mathrm{HT}_{7}$ specific SB in cells that express only $5-\mathrm{HT}_{7}(22 \pm 5 \%, \mathrm{n}=15)$ or coexpress $5-\mathrm{HT}_{7}$ and $5-\mathrm{HT}_{1 \mathrm{~A}}(90 \pm 7 \%, \mathrm{n}=39)$

\subsection{G-Protein interaction}

In order to track the signal transmission further downstream, the signaling cascade should be investigated on the $G$ protein level. To determine by which $G$ protein receptor stimulation of a putative $5-\mathrm{HT}_{1 \mathrm{~A}}-5-\mathrm{HT}_{7}$ hetero-oligomer is mediated cells were incubated overnight in 0.1 $\mu \mathrm{g} / \mathrm{ml}$ pertussis toxin, a known inhibitor of $\mathrm{G}_{\mathrm{i}}$. Again, 5- $\mathrm{HT}_{1 \mathrm{~A}}$ receptors, when expressed alone, usually inhibit $A C$ via $G_{i}$ whereas $5-H T_{7}$ receptors activate $A C$ via $G_{s}$. After pertussis treatment coexpressing cells exhibited no $E f_{D A} / V$ response to $1 \mu \mathrm{M} 5-\mathrm{HT}\left(\Delta E f_{D A} / V=+0.02 \pm\right.$ 0.01) (Fig. 3.11), which signifies the dominance of the $\mathrm{G}_{i}$ pathway in case of $5-\mathrm{HT}_{1 \mathrm{~A}}-5-\mathrm{HT}_{7}$ receptor coexpression. Additional measurements using a dominant inactive mutant of $\mathrm{G}_{\mathrm{i}}$, transfected in advance, confirmed these findings. Co-transfection of the $G_{i}$ mutant diminished the $E f_{D A} / Y$ response to $5-\mathrm{HT}$ to nearly one third of control values in $5-\mathrm{HT}_{7}-5-\mathrm{HT}_{1 \mathrm{~A}}$ 
Results

coexpressing cells (Fig. 3.11). The remaining $E f_{D A} / Y$ change can most probably be attributed to activity of endogenous $G_{i}$ proteins.

\section{Excitation after Gi block}

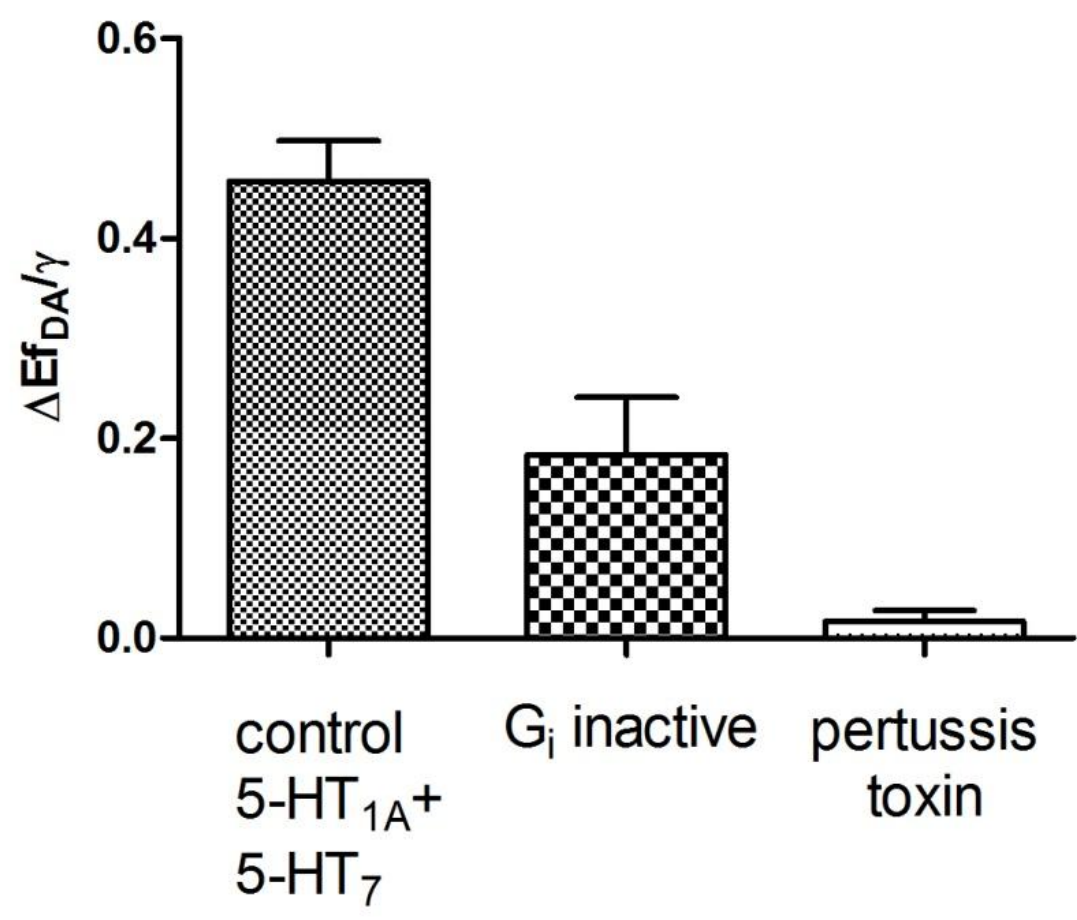

Fig. 3.11 [CAMP] changes at $G_{i}$ protein block

$\mathrm{Ef}_{\mathrm{DA}} / \mathrm{Y}$ change after stimulation with $1 \mu \mathrm{M} 5-\mathrm{HT}$ in $5-\mathrm{HT}_{1 \mathrm{~A}}-5-\mathrm{HT}_{7}$ coexpressing cells. Experimental setup as described in 3.2. Error bars, SE. $E f_{D A} / Y$ reaction is inversely proportional to [CAMP] development. Previous transfection of a dominant inactive $G_{i}$ protein mutant diminishes the effect to one third of the control value. Control: $0.46 \pm 0.04$ ( $n=36$ cells/ROIs), $G_{i}$ mutant: $0.18 \pm 0.06(n=40)$. Pretreatment with pertussis toxin $\left(0.1 \mu \mathrm{g} / \mathrm{ml}\right.$ overnight), a known $\mathrm{G}_{\mathrm{i}}$ inhibitor almost totally blocks the activation. (0.02 $\pm 0.01, \mathrm{n}=38)$

\subsection{Biosensor efficiency}

In early experiments the formerly used biosensor EPAC was utilized. In contrast to the newly developped CEPAC* construct, the older EPAC sensor carries the FRET pair CFP/YFP instead of mCerulaen and mCitrine. In many respects the new biosensor appears to be superior. Thus, CEPAC* exhibits a wider ion tolerance, increased dynamic range of the 
Results

FRET efficiency response and a prolonged time window for stable experiments (Salonikidis et al. 2011). These results could be supported by comparing the fraction of reacting cells after transfection of either the old or the new sensor (Fig. 3.12). In FRET measurements not all transfected cells regularly reacted to receptor activation. CEPAC* transfected cells revealed a success rate of $89 \pm 9 \%$ compared to only $33 \pm 7 \%$ in measurements with EPAC transfected cells. The Figure shows data of FRET measurements in 5-HT ${ }_{1 \mathrm{~A}}$ receptor expressing cells which were either transfected with the older EPAC sensor or the new CEPAC* $^{*}$ in 7 and 8 different preparations, respectively. The results were published in Salonikidis 2011 (Salonikidis et al. 2011). The new construct helped to make the experiments more constant and the here presented results more reliable. It increased the number of measuring cells and therefore the significance of the data.

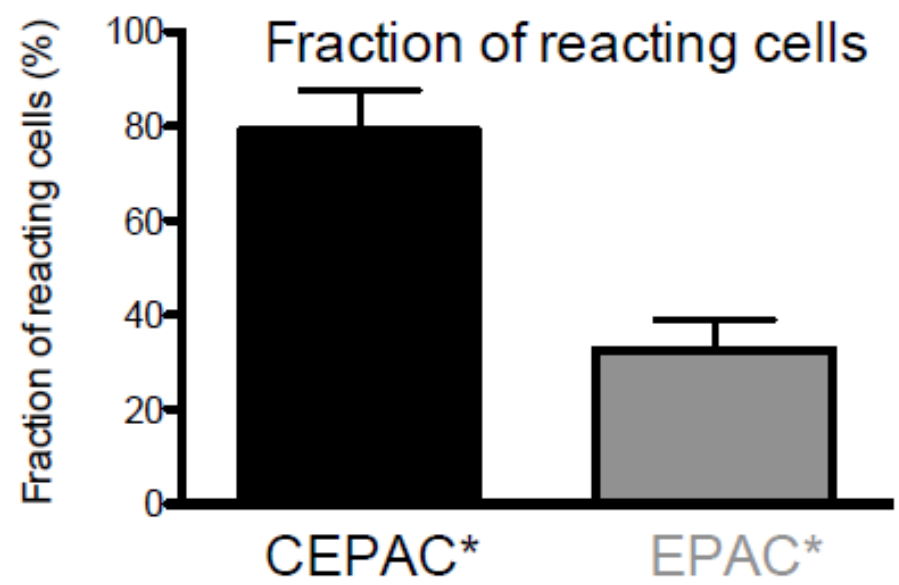

\section{Fig. 3.12 Sensor dependant fraction of reacting cells}

The figure shows the percentage of cells reacting to stimulation for each respective biosensor, given as the mean and S.D. (error bars) of cAMP response rates. These experiments were done in N1E cells co-transfected with the $5-\mathrm{HT}_{1 \mathrm{~A}}$ receptor together with CEPAC* or EPAC from eight and seven different preparations, respectively. 


\section{Discussion}

\subsection{Receptor crosstalk - coexpression generates novel functionality}

The conducted experiments allowed the investigation of $5-\mathrm{HT}_{1 \mathrm{~A}}$ and $5-\mathrm{HT}_{7}$ receptor crosstalk in coexpressing cells. A strong serotonergic innervation is evident in manifold human brain structures such as amygdala, cerebral cortex, striatum and hippocampus (Azmitia and Gannon 1986). 5- $\mathrm{HT}_{1 \mathrm{~A}}$ and $5-\mathrm{HT}_{7}$ receptors are physiologically coexpressed in the same neuronal cells as shown for CA1 hippocampal neurons (Bickmeyer et al. 2002, Neumaier et al. 2001, Azmitia et al. 1996, Kia et al. 1996) and neurons in the prefrontal cortex in rodent and primate brains. Figure 1.6 illustrates $5-\mathrm{HT}_{1 \mathrm{~A}}-5-\mathrm{HT}_{7}$ coexpressing cells in the preBötzinger complex of the ventrolateral medulla of the brainstem (Kindly provided by Dr.Dr. Till Manzke). Considering physiological occurrence of both receptors in the same neurons it is of particular interest to investigate $5-\mathrm{HT}_{1 \mathrm{~A}}-5-\mathrm{HT}_{7}$ interaction with regard to their countercooperative impact on the adenylyl cyclase. 5- $\mathrm{HT}_{1 \mathrm{~A}}$ receptors, when expressed alone, are known to negatively couple to $A C$ via inhibitory $G_{i}$ proteins and consequently to decrease the cellular cAMP concentration. $5-\mathrm{HT}_{7}$ receptors in contrast increase [CAMP] via stimulating $\mathrm{G}_{\mathrm{s}}$ proteins. Control measurements supported this paradigm for the test setup utilized in the current thesis (Fig. 3.6). A live imaging FRET approach was chosen so that the cellular [CAMP] trend could be analyzed in single living cells during stimulation in real-time. Thus, it was possible to deduce what impact each receptor subtype exerted when they are coexpressed in the same cells and which receptor pathway potentially appeared to be dominant. Prior to the coexpression experiments, it was necessary to prove that both receptors were expressed in equal amounts. This was realized by receptor labeling and visual selection. An additional consideration is that many GPCRs, including serotonin receptors 5- $\mathrm{HT}_{1 \mathrm{~A}}$ and 5- $\mathrm{HT}_{7}$, tend to oligomerize (Lee 2004, Woehler and Ponimaskin 2009, Kobe et al. 2008) which often results in altered signaling properties. Hetero-oligomerization of $5-\mathrm{HT}_{1 \mathrm{~A}}$ and $5-\mathrm{HT}_{7}$ might occur to varying extends, but in any case a strong functional interaction became evident in this analysis. The fundamental observation in this work is that treatment of $5-\mathrm{HT}_{1 \mathrm{~A}}-5-\mathrm{HT}_{7}$ coexpressing cells with serotonin or even with the $5-\mathrm{HT}_{7}$ receptor specific agonist AS19 leads to a strong $5-\mathrm{HT}_{1 \mathrm{~A}}$ like [CAMP] decrease $\left(E f_{D A} / V\right.$ increase) (Fig. 3.6; Fig. 3.10). The $G_{i}$ mediated $A C$ inhibition clearly presents itself dominant towards activation. Specific antagonists for $5-\mathrm{HT}_{1 \mathrm{~A}}(\mathrm{WAY})$ and $5-\mathrm{HT}_{7}(\mathrm{SB})$, respectively, were able to block this serotonin evoked $A C$ inhibition about $92 \pm 7 \%$ and $75 \pm 4 \%$ (Fig. 3.9). However, the fact that the $5-\mathrm{HT}_{7}$ specific antagonist $\mathrm{SB}$ had no effect on $5-\mathrm{HT}_{1 \mathrm{~A}}$ receptors in 
control experiments (Fig. 3.7) excludes a mere dominance of $5-\mathrm{HT}_{1 \mathrm{~A}}$ receptors in the coexpression model. Instead, a complex receptor interaction becomes apparent. Blockade of the $G_{i}$ protein was performed to further track the pathway and gather additional information about the nature of the $5-\mathrm{HT}_{1 \mathrm{~A}}-5-\mathrm{HT}_{7}$ interference. Pre-treatment of the coexpressing cells with the known $G_{i}$ inhibitor pertussis toxin entirely blocked the signaling pathway (Fig. 3.11). In addition, cotransfection of a dominant inactive $G_{i}$ protein mutant also diminished the [CAMP] decrease after 5-HT application to one third of the control value (Fig. 3.11). A model illustrates the newly observed signaling patterns in figure 4.1 under assumption of a potential $5-\mathrm{HT}_{1 \mathrm{~A}}-5-\mathrm{HT}_{7}$ heterodimer. It seems reasonable to suppose that the agonist and antagonist binding sites of both receptor subtypes are still functional in the coexpression model, since both specific antagonists inhibited signal transmission. In control measurements, by contrast, specific antagonists hardly blocked receptor activation of the other non-specific receptor (Fig. 3.7). Nevertheless, there are now multiple possibilities that could explain the newly found signaling features. Coexpression might have induced a $5-\mathrm{HT}_{1 \mathrm{~A}}-5-\mathrm{HT}_{7}$ receptor oligomer that couples to the $G_{i}$ protein and can be coactivated and/or trans-inhibited. But, coexpression might also have changed the affinities for formerly specific agonists and antagonists or the selectivity for $\mathrm{G}$ proteins might have altered. These reflections are going to be discussed in detail in the following chapters. 


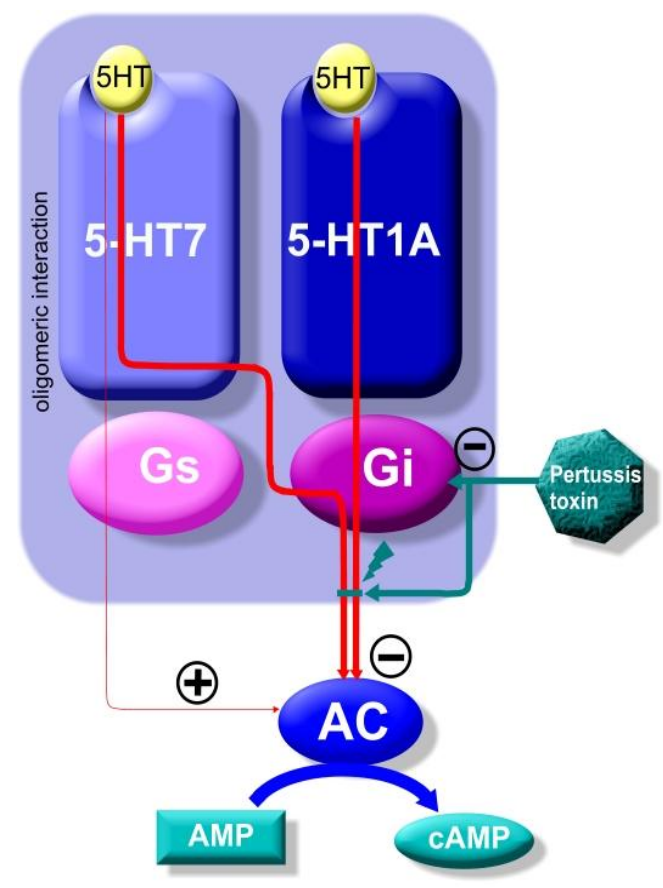

Fig. 4.1 Signaling properties in $5-\mathrm{HT}_{1 \mathrm{~A}}-5-\mathrm{HT}_{7}$ coexpressing cells on the basis of a putative hetero-oligomer

The model illustrates the observed signaling patterns in $5-\mathrm{HT}_{7}$ and $5-\mathrm{HT}_{1 \mathrm{~A}}$ receptor coexpressing cells under assumption of a potential heterodimer. Serotonin application in coexpressing cells leads to $G_{i}$ mediated, pertussis toxin sensitive AC inhibition and [CAMP] decrease in the following. Red lines indicate the assumed signaling pathways after $5-\mathrm{HT}_{7}-5-\mathrm{HT}_{1 \mathrm{~A}}$ coactivation. Thick lines show common $A C$ inhibition via $G_{i}$; Thin line indicates possible, residual $G_{s}$ activation. Abbreviations: $5 H T$, serotonin; 5-HT7/1A, serotonin receptor subtypes 7/1A; Gs, G-protein subunit as; Gi, G-protein subunit ai; AC, adenylyl cyclase, AMP, adenosin monophosphate; cAMP, cyclic adenosin monophosphate.

\subsubsection{Oligomerization, coactivation and trans-inhibition}

The newly found signaling features, illustrated in figure 4.1, are the reflection of receptor interaction on one or more level of the downstream pathway, from activation over direct receptor interference to $G$ protein-coupling and $A C$ acquisition. Formation of a receptor oligomer that can be coactivated and trans-inhibited is one option that could account for the new observations. Many GPCRs build oligomers (Woehler and Ponimaskin 2009, Kobe et al. 2008). 5- $\mathrm{HT}_{1 \mathrm{~A}}$ receptors have been shown to form homo-oligomers. As pointed out earlier, collaborating groups revealed that $5-\mathrm{HT}_{1 \mathrm{~A}}$ and $5-\mathrm{HT}_{7}$ also hetero-oligomerize in vitro and in vivo as shown in mouse hippocampal neurons (Renner et al. 2012). As a matter of fact, 
oligomerization of GPCRs has been shown to alter signaling properties in a vast number of cases. Upon oligomerization conformational changes of the monomeric subunits occur and in doing so, affect signaling. Thus Rocheville et al. (Rocheville 2000) revealed that dopamine receptors $\mathrm{D} 2 \mathrm{R}$ and somatostatin receptors SSTR5 interact physically through heterooligomerization in $\mathrm{CHO}-\mathrm{K} 1$ cells and therefore create a novel receptor with enhanced functional activity. They show that in coexpressing cells the SSTR5 agonist somatostatin-14 is capable of activating the DR2 downstream signaling pathway and suggest that this is a consequence of different conformational states of the agonist- or antagonist-occupied receptor complex.

Figure 3.6 reveals that serotonin application to $5-\mathrm{HT}_{1 \mathrm{~A}}-5-\mathrm{HT}_{7}$ coexpressing cells leads to [CAMP] decrease as seen before in $5-\mathrm{HT}_{1 \mathrm{~A}}$ - only expressing cells. Common activation of the putative $5-\mathrm{HT}_{1 \mathrm{~A}}-5-\mathrm{HT}_{7}$ heterodimer as shown in the scheme above (Fig. 4.1) would, in this case, comparably to the observations from Rocheville et al. recruit $G_{i}$ protein and consequently inhibit AC. However, Renner et al. (2012) revealed in GTPYS coupling assays (Kvachnina et al. 2005) that $5-\mathrm{HT}_{1 \mathrm{~A}}-5-\mathrm{HT}_{7}$ hetero-oligomerization leads to decreased activation of $\mathrm{G}_{i}$ protein through $5-\mathrm{HT}_{1 \mathrm{~A}}$. These findings might differ from the results in the actual thesis for various reasons and are going to be discussed in 4.1.4. The ability of the 5$\mathrm{HT}_{7}$ specific agonist AS19 to trigger the $\mathrm{G}_{i}$ pathway in coexpressing cells (Fig.3.10) might constitute a similar transactivation. The AS19 experiments are going to be discussed in 4.1.3.

Besides that, Barki-Harrington et al. (Barki-Harrington 2003) also reported trans-inhibition of putative $\beta$-adrenergic receptor and angiotensin II type 1 receptor hetero-oligomers in mouse cardiomyocytes. Specific inhibition of one receptor could in this case efficiently prevent signaling of the other respective receptor. The $5-\mathrm{HT}_{7}$ specific antagonist $\mathrm{SB}$ is able to block the $\mathrm{G}_{i}$ mediated [cAMP] descent in $5-\mathrm{HT}_{1 \mathrm{~A}}-5-\mathrm{HT}_{7}$ coexpressing cells (Fig. 3.9), whereas $\mathrm{SB}$ had no effect on $5-\mathrm{HT}_{1 \mathrm{~A}}$ receptors in control measurements (Fig. 3.7). This phenomenon might be due to trans-inhibition similar to the observations from Barki-Harrington et al. Similarly, $5-\mathrm{HT}_{7}$ signaling is crucial for serotonin mediated $5-\mathrm{HT}_{1 \mathrm{~A}}$ internalization, which gets interrupted upon SB application in coexpressing cells (Renner et al. 2012).

These experiments could not reveal whether $5-\mathrm{HT}_{1 \mathrm{~A}}-5-\mathrm{HT}_{7}$ oligomers are responsible for the new signaling properties. Nevertheless, there is no doubt that the two receptors, when expressed together, interact and display signaling patterns different from when they are expressed alone. A change of the agonist and/or antagonist affinities as well as modified 
G protein coupling selectivities could also account for the new signaling features and are going to be discussed below.

\subsubsection{Effect of coexpression on receptor pharmacology - altered agonist- and antagonist affinities}

As mentioned above, coexpression and potentially oligomerization can lead to altered affinities for agonists or antagonists compared to the affinities of the single receptors. Upon coexpression of $\mu$-and $\delta$-opioid receptors in COS-7 cells, George (George 2000) observed reduced potency and altered rank order of highly selective synthetic agonists for each, whereas endomorphin-1 and Leu-enkephalin showed enhanced affinity, suggesting the formation of a novel binding pocket. (see also Gomes et al. 2000) That raises the question whether the dominance of the $\mathrm{G}_{\mathrm{i}}$-pathway in the actual investigation can be explained by changed receptor pharmacology. Application of serotonin in $5-\mathrm{HT}_{1 \mathrm{~A}}-5-\mathrm{HT}_{7}$ coexpressing cells caused a [CAMP] decrease, even slightly stronger than in $5-\mathrm{HT}_{1 \mathrm{~A}}$ - only expressing cells (Fig. 3.6). Supposing that a change of agonist affinities was responsible for this phenomenon would mean that the $5-\mathrm{HT}_{1 \mathrm{~A}}$ receptor had become more and the $5-\mathrm{HT}_{7}$ receptor less affine for serotonin. Again, the $5-\mathrm{HT}_{7}$ specific antagonist $\mathrm{SB}$ blocked the $\mathrm{AC}$ inhibition (Fig. 3.9). Consequently, there also had to be an analogue change of antagonist affinities for both receptors. As expected, the $5-\mathrm{HT}_{1 \mathrm{~A}}$ specific antagonist WAY was able to block the AC inhibition too. Its blocking ability appeared slightly enhanced; $92 \pm 7 \%$ upon coexpression versus $77 \pm 7 \%$ in $5-\mathrm{HT}_{1 \mathrm{~A}}$ - single expression. If affinity changes for agonists and antagonists accounted for the altered signaling properties under coexpression, multiple changes must have occurred. The $5-\mathrm{HT}_{1 \mathrm{~A}}$ receptor subtype would have generally gained stronger affinities for serotonin, $\mathrm{SB}$ and WAY, whereas $5-\mathrm{HT}_{7}$ binding sites would exhibit reduced affinities. Figure 3.7 shows the blocking abilities of $\mathrm{SB}$ and WAY in $5-\mathrm{HT}_{7}-$ only or $5-\mathrm{HT}_{1 \mathrm{~A}}-$ only expressing cells. SB can block $5-\mathrm{HT}_{7}$ receptor activation to $70 \pm 6 \%$ and 5 $\mathrm{HT}_{1 \mathrm{~A}}$ receptors just to $3 \pm 1 \%$. These results are in accordance to the literature $\mathrm{K}_{\mathrm{i}}$ values (Lovell et al. 2000, Hagan et al. 2000) and confirm (SB) antagonist selectivity for $5-\mathrm{HT}_{7}$ when expressed alone. WAY also appears selective, albeit for $5-\mathrm{HT}_{1 \mathrm{~A}}$ of course, in these controls. (Chemel et al. 2006)

$5-\mathrm{HT}_{1 \mathrm{~A}}-5-\mathrm{HT}_{7}$ coexpressing cells were further stimulated with $5-\mathrm{HT}_{7}$ specific AS19, also leading to AC inhibition ([CAMP] decrease) (Fig. 3.10) (see 4.1.3). AS19 application in 5-HT - only expressing cells increases [CAMP], as expected. Accordingly, the two receptors might 
have altered their affinities for this agonist upon coexpression with the result that $5-\mathrm{HT}_{1 \mathrm{~A}}$ gained and $5-\mathrm{HT}_{7}$ lost affinity for AS19.

\subsubsection{AS19 experiments}

Activation of $5-\mathrm{HT}_{1 \mathrm{~A}}-5-\mathrm{HT}_{7}$ coexpressing cells with the $5-\mathrm{HT}_{7}$ receptor specific agonist AS19 led to AC inhibition ([CAMP] decrease) to almost the same extent as with serotonin (Fig. 3.10). Subsequently, $\mathrm{AC}$ inhibition is blocked by the $5-\mathrm{HT}_{7}$ receptor specific antagonist $\mathrm{SB}$ to $90 \pm 7 \%$ (Fig. 3.10, B). Hence, the same picture is repeated as with serotonin. The $G_{i}$ mediated [cAMP] lowering appears dominant and the, usually $\mathrm{G}_{\mathrm{s}}$ - coupled, 5- $\mathrm{HT}_{7}$ receptor does not seem to exert any impact. In control experiments AS19, in the used concentration of $100 \mathrm{nM}$, was not able to activate $5-\mathrm{HT}_{1 \mathrm{~A}}$ receptors while $5-\mathrm{HT}_{7}$ receptors displayed a moderate response (Fig. 3.10). The literature $K_{i}$ values for $A S 19$ are $4.6 \mathrm{nM}$ for $5-\mathrm{HT}_{7}$ and $110 \mathrm{nM}$ for $5-\mathrm{HT}_{1 \mathrm{~A}}$ (Bosker et al. 2009). Due to dilution in the measuring chamber $100 \mathrm{~nm}$ AS19 apparently was not sufficient to activate $5-\mathrm{HT}_{1 \mathrm{~A}}$ receptors, but $5-\mathrm{HT}_{7}$ receptors to a certain extent. At first appearance, it seems contradictory that unilateral activation elicits a [CAMP] decrease whereas inhibition of either receptor in prior experiments almost totally blocked signaling (Fig. 3.9). However, going back to the previously discussed feature of transactivation, this could be a result of the receptor interaction and/or oligomerization, respectively (Rocheville 2000) (see 4.1.1). In that case $S B$ would similarly trans-inhibit $G_{i}$ activation. It is also conceivable that the receptors change their affinities for AS19 upon coexpression/oligomerization as discussed above (see 4.1.2). $5-\mathrm{HT}_{1 \mathrm{~A}}$ receptors would then have become more and $5-\mathrm{HT}_{7}$ receptors less affine for AS19. Consequently, AS19 could activate $5-\mathrm{HT}_{1 \mathrm{~A}}$ and trigger the $\mathrm{G}_{i}$ protein pathway.

\subsubsection{Diversity in G protein-coupling}

$5-\mathrm{HT}_{1 \mathrm{~A}}-5-\mathrm{HT}_{7}$ coexpressing cells respond to serotonin or AS19 application with [CAMP] decrease (see Fig. 3.6, Fig.3.10, and 4.1.1 - 4.1.3). In the previous chapters features like transactivation, trans-inhibition or changed agonist affinities have been discussed as reason for this $G_{i}$ pathway dominance. Usually $5-H T_{1 A}$ receptors couple to $G_{i}$ and $5-H T_{7}$ to $G_{s}$. However, coexpression of $5-\mathrm{HT}_{1 \mathrm{~A}}$ and $5-\mathrm{HT}_{7}$ might have altered their $\mathrm{G}$ protein-coupling selectivities as alternative explanation for the new observations. 
Principally, many GPCRs have the ability to transduce signal through a variety of G proteins. The 5- $-\mathrm{HT}_{4}$-receptor for instance is described to couple to $\mathrm{G}_{i}$ and $\mathrm{G}_{\mathrm{s}}$ (Pindon et al. 2002). Additionally, oligomerization can modify $G$ protein-coupling selectivity. Barki and Harrington (2000) revealed, that hetero-oligomerization of $\beta$-adrenergic receptors and angiotensin II type 1 receptor in mouse cardiomyocytes can lead to a covering of $\mathrm{G}$ protein binding sites. They assume that blocking of either $\beta A R s$ or $A T_{1} R s$ in the putative heterodimer induces $a$ conformational change that is no longer favorable to support the interaction of the other receptor with its $\mathrm{G}$ protein. Moreover, oligomerization can generate novel $\mathrm{G}$ protein binding sites distinct from those of their constituent receptors (Lee 2004). Similarly, a potential 5$\mathrm{HT}_{1 \mathrm{~A}}-5-\mathrm{HT}_{7}$ receptor oligomer might exhibit a changed $\mathrm{G}$ protein-coupling profile compared to the single receptors. Since 5-HT activation of the putative $5-\mathrm{HT}_{1 \mathrm{~A}}-5-\mathrm{HT}_{7}$ receptor oligomer in the actual study induces AC inhibition ([CAMP decrease]), it seems likely that the majority of the oligomers are coupled to $G_{i}$ not to $G_{s}$. Upon blockade of $G_{i}$ protein-coupling to the receptors, using pertussis toxin (PTX) or transfection of a dominant inactive $G_{i}$ mutante (Fig. 3.11 ), the [CAMP] decrease is totally absent or reduced to one third, respectively. It is therefore evident that the effect is $G_{i}$ mediated. The number of remaining bound $G_{s}$ is obviously not high enough to activate AC, as no [CAMP] increase was detectable after 5-HT application. It can therefore be assumed that the putative oligomer might possess a minor affinity for $G_{s}$ and a higher affinity for $G_{i}$. However, Renner et al. (2012) found a decreased activation of $\mathrm{G}_{\mathrm{i}}$ through $5-\mathrm{HT}_{1 \mathrm{~A}}$, when coexpressed with 5- $\mathrm{HT}_{7}$, in GTPYS coupling assays. 5$\mathrm{HT}_{7}$ mediated $\mathrm{G}_{\mathrm{s}}$ activation in contrast seemed not to be affected. These contradictory findings to the results shown above (Fig. 3.6) could have different reasons. It is conceivable that the different protocols and approaches accounted for the difference. All coexpression experiments in this thesis have been conducted in presence of $100 \mathrm{nM}$ forskolin in order to elevate the cellular [cAMP] to a mean level. Different initial [cAMP] values could lead to either blunted or enhanced coupling of $G_{i}$. Moreover, Renner et al. used GTPYS proteins to examine $G$ protein coupling whereas in this thesis [CAMP] was measured after receptor stimulation, which constitutes another endpoint of the signaling cascade. The use of GTPYS and antibodies directed against $G$ proteins could yield different results as the pure measuring of [CAMP]. On the other hand, it is possible that the results do not interfere, but that the here presented decrease in [cAMP] is not consequence of enhanced $G_{i}$ activation by $5-H_{1} T_{1 A}$ but of additional $G_{i}$ coupling to $5-\mathrm{HT}_{7}$, disturbed $\mathrm{G}_{\mathrm{s}}$ activation of $A C$ or potential effects of the $\mathrm{G}$ protein $\beta y$-subunits (also see 4.3). Renner et al. (2012) also report augmented $5-\mathrm{HT}_{1 \mathrm{~A}}$ internalization upon $5-\mathrm{HT}_{1 \mathrm{~A}}-5-\mathrm{HT}_{7}$ hetero-oligomerization. Similarly, one would expect a diminished role of $5-\mathrm{HT}_{1 \mathrm{~A}}$ under these circumstances. It is again feasible that $5-\mathrm{HT}_{1 \mathrm{~A}}$ internalization in this approach behaves differentially or that the remaining $5-\mathrm{HT}_{1 \mathrm{~A}}$ receptors 
more effectively succeed in recruiting $G_{i}$ proteins. Additionally, Renner et al. (2012) reveal synergistic interaction of $5-\mathrm{HT}_{1 \mathrm{~A}}$ and $5-\mathrm{HT}_{7}$ when they show that heterodimerization increases the $5-\mathrm{HT}_{1 \mathrm{~A}}$ mediated phosphorylation of the MAP kinase Erk1.

As mentioned above a further possibility for the here presented dominance of the $G_{i}$ pathway in the $5-\mathrm{HT}_{1 \mathrm{~A}}-5-\mathrm{HT}_{7}$ coexpression model is additional $\mathrm{G}_{\mathrm{i}}$ coupling to the $5-\mathrm{HT}_{7}$ receptor. In this case both receptors would couple to $\mathrm{G}_{\mathrm{i}}$ and $5-\mathrm{HT}_{7}$ receptor agonists and antagonists could influence the $G_{i}$ pathway as well. Nevertheless, a mere additional $G_{i}$ binding to $5-\mathrm{HT}_{7}$ could not explain that the $5-\mathrm{HT}_{1 \mathrm{~A}}$ specific antagonist WAY and the $5-\mathrm{HT}_{7}$ specific antagonist SB both blocked the [CAMP] decrease to $92 \pm 7 \%$ and $75 \pm 4 \%$, respectively. The not-blocked other respective receptor would still activate $G_{i}$ proteins. Consequently, the total [CAMP] decrease would be lowered but presumably not on this scale, especially considering that each antagonist blocked its specific receptor to an even lesser extent in control measurements. (Fig. 3.7)

The stoichiometry between GPCRs and G proteins might also have an influence on signaling. Homodimers of human leukotriene B4 (LTB4) receptors BLT1 bind only to one $G$ protein (Banères and Parello 2003). Such a $2: 1$ - R : G protein stoichiometry could also exist in the case of the putative $5-\mathrm{HT}_{1 \mathrm{~A}}-5-\mathrm{HT}_{7}$ receptor oligomer. Cases have been reported, in which only one subunit of a dimer binds to a $G$ protein, whereas the other one serves as a docking platform and loses its coupling ability (Filipek et al. 2004). In a potential 5-HT ${ }_{1 \mathrm{~A}}-5$ $\mathrm{HT}_{7}$ dimer, $5-\mathrm{HT}_{7}$ might have lost its coupling ability to $\mathrm{G}_{\mathrm{s}}$.

Renner et al. (2012) showed that oligomerization of 5- $\mathrm{HT}_{1 \mathrm{~A}}$ and $5-\mathrm{HT}_{7}$ happens regularly in vitro and in vivo and that $5-\mathrm{HT}_{7}$ receptors possess a higher potential to form homodimers than for $5-\mathrm{HT}_{1 \mathrm{~A}}$ and $5-\mathrm{HT}_{7}$ to heterodimerize. Altough, heterodimerization occurs more often in the lux-FRET based dimerization model than $5-\mathrm{HT}_{1 \mathrm{~A}}$ homodimerization. It is therefore more likely, that the altered signaling behavior, presented in this thesis, is the result of interaction in a putative heterodimer than of $5-\mathrm{HT}_{1 \mathrm{~A}}$ homodimers. Nevertheless, it is still possible, that homodimers play a role in the observed processes. Homodimerization of 5 $H T_{1 A}$, even if less often could be responsible for the $G_{i}$ dominance. On the other hand, even $5-\mathrm{HT}_{7}$ dimers could, assuming a changed signaling bahvior compared to monomers, account for the effect. 


\subsection{Coexpression analysis, receptor distribution and fluorescence labeling}

To examine the interaction of the two serotonin receptor subtypes $5-\mathrm{HT}_{1 \mathrm{~A}}$ and $5-\mathrm{HT}_{7}$ in this coexpression model, it is important to have an equal expression of both in the investigated cells.

Visual selection via fluorescence receptor labeling was performed prior to all FRET experiments to analyze only these cells which coexpressed both receptors, as possible in equal shares (Fig. 3.2). Fig. 3.8 illustrates that $5-\mathrm{HT}_{1 \mathrm{~A}}$ receptors exhibited weaker $E f_{D A} / Y$ response to serotonin when tagged to mCherry. When marked with fluorescent quantum dots in contrast the responses were as strong as in the controls. $5-\mathrm{HT}_{7}$ receptors seemed not to be affected by mCherry tags in their ability to decrease $E f_{D A} / V$ (increase cAMP). Consequently, $5-\mathrm{HT}_{7}$ receptors were labeled with mCherry and $5-\mathrm{HT}_{1 \mathrm{~A}}$ receptors with QDs in further coexpression experiments. It was nonetheless not possible to determine the exact receptor distribution and percentage of each receptor in every single measured cell. However, FACS analysis of cells, transfected with fluorescence labeled $5-\mathrm{HT}_{1 \mathrm{~A}}$ or $5-\mathrm{HT}_{7}$ receptors in equal amounts, revealed virtually no difference in receptor expression (Experiments were conducted by Dr. Marcus Niebert) (Fig. 3.1). Moreover, functional analysis showed the influence and consequently the presence of both receptors in coexpressing cells in functionally significant amounts. Both antagonists, the $5-\mathrm{HT}_{1 \mathrm{~A}}$ selective WAY and the $5-\mathrm{HT}_{7}$ selective $\mathrm{SB}$, were able to block $5-\mathrm{HT}$ induced [CAMP] decrease in coexpressing cells (Fig. 3.9). The block was even more effective than in cells which expressed only each respective receptor alone (Fig. 3.7)(see also 4.1.4). In these control measurements each antagonist was hardly able to inhibit the nonselective receptor so that unselectivity of the antagonists is not the reason for the strong blocking abilities in coexpressing cells (Fig. 3.7). It is therefore evident that both receptors are present in coexpressing cells in sufficient amount to have an effect on [CAMP] (see also 4.1.2). Furthermore, this functional verification actually proofs receptor presence in the membrane and not in the cytosol because antagonists do not pass the membrane.

Taken together all this evidence strongly suggests a balanced expression of both receptors in measuring cells.

One more observation supports the theory of equal receptor expression. As mentioned above fluorescent antibodies unambiguously confirmed the presence of both receptors in each analyzed cell. However, since the $G_{i}$ pathway in coexpression experiments appears clearly dominant it is conceivable that $5-\mathrm{HT}_{1 \mathrm{~A}}$ receptors might be significantly more 
expressed than $5-\mathrm{HT}_{7}$ in these cells. There is one more important fact, alongside all the other measures, that contradicts this assumption. After 5-HT application, the cells demonstrated, as already noted, a strong [CAMP] decrease. Specific $5-\mathrm{HT}_{1 \mathrm{~A}}$ receptor inhibition in these cells did not result in an overshooting cAMP production. If just a higher expression of $5-\mathrm{HT}_{1 \mathrm{~A}}$ was responsible for the $G_{i}$ pathway dominance, one could expect a raise of the cAMP production by the remaining $5-\mathrm{HT}_{7}$ receptors after total $5-\mathrm{HT}_{1 \mathrm{~A}}$ inhibition. Again, $5-\mathrm{HT}_{7}$ receptors alone considerably increased [CAMP] (Fig. 3.6). Instead, the total [CAMP] trend is still negative after $5-\mathrm{HT}_{1 \mathrm{~A}}$ blockade (Fig. 3.9). But since $5-\mathrm{HT}_{7}$ receptors had previously been identified optically in these cells, there has to be another reason for the $G_{i}$ dominance as discussed in 4.1 4.1.4.

\subsection{1 cAMP microdomains}

The distribution of receptors in the cellular plasma membrane has major impact on signaling. Many studies have shown that GPCRs localize in certain cholesterol-rich compartments or microdomains for fast and efficient signal transduction (Foster et al. 2003). It has been suggested that these microenvironments, also known as lipid rafts, contain exchangeable sets of signaling elements and therefore favor specific protein-protein interactions and subsequent pathway modifications (Simons and Toomre 2000). There is unequivocal evidence that compartmentalized cAMP signaling occurs (Agarwal et al. 2011, Steinberg and Brunton 2001, Lingwood and Simons 2010) and $5-\mathrm{HT}_{1 \mathrm{~A}}$ and $5-\mathrm{HT}_{7}$ receptors might also cumulate in such microdomains. The close proximity in these areas might likewise favor oligomerization of the two receptors. However, the FRET method in the actual thesis gathers the averaged signal of the entire cell. Throughout the whole cell, cAMP triggers the conformational change of the FRET sensor and the microscope measures the fluorescence of membrane associated and cytosolyc compartmens. Consequently, the acquired data contain areas with high and others with low density of the expressed $5-\mathrm{HT}$ receptors. Measuring of distinct cAMP microdomains close to the membrane might even deliver stronger or faster signals. 


\subsection{Signal transmission and crosstalk by G protein- $\beta y$ subunits}

In the present investigation it has been shown that serotonin activation of $5-\mathrm{HT}_{1 \mathrm{~A}}-5-\mathrm{HT}_{7}$ receptor coexpressing cells diminishes the cellular cAMP concentration (Fig. 3.6). Other studies suggested that the $G_{\beta \gamma}$ subunits of heterotrimeric $G$ proteins might, in addition to $G_{\alpha}$ subunits, stimulate or inhibit the cAMP forming enzyme adenyly cyclase (Nielsen et al. 1991). This conclusion would mean that the [CAMP] decrease after serotonin application in $5-\mathrm{HT}_{1 \mathrm{~A}}-$ $5-\mathrm{HT}_{7}$ coexpressing cells might as well be induced by $\mathrm{G}_{\beta \gamma}$ instead of $\mathrm{G}_{\mathrm{i}}$. However, these findings were made under very special conditions and therefore a major impact of $G_{\beta y}$ on $A C$ can be excluded for the current thesis. Besides, Renner et al. (2012) rather report diminished function of $\mathrm{G}_{\beta Y}$ subunits upon $5-\mathrm{HT}_{1 \mathrm{~A}}-5-\mathrm{HT}_{7}$ hetero-oligomerization since interaction of the two receptors markedly decreased activation of G-protein-gated inwardly rectifying potassium (GIRK or Kir3) channels by $5-\mathrm{HT}_{1 \mathrm{~A}}$.

When $G_{\alpha}$ subunits of $G$ proteins get activated, $G_{\beta \gamma}$ units dissociate, trigger targets on their own and reassociate with $G_{\alpha}$ units to enter a new signaling cycle. In contrast to receptor - $G_{\alpha}$ coupling, there is little selectively between $G_{\alpha}$ and $G_{\beta \gamma}$ coupling, resulting in a shared pool of these subunits (Woehler and Ponimaskin 2009).

In 1991 Nielsen et al. revealed that in insect ovarian Sf9 cells $G_{\beta \gamma}$ subunits of $G$ proteins were able to either inhibit or stimulate AC dependant on the AC subtype (calmodulin-sensitive vs. not calmodulin-sensitive) (Nielsen et al. 1991). Nevertheless, these effects occurred only in the presence of recombinant $\mathrm{G}_{\mathrm{s \alpha}}\left(\mathrm{rG}_{\mathrm{sa}}\right)$ activated with guanosine-5'-O-(3-thiotriphosphate) (GTP-y-S). GTP-y-S binds to $G_{s a}$ with high affinity and subsequently prevents $G_{\beta y}$ from reassociating with $G_{s \alpha}$. Consequently, $G_{\beta \gamma}$ subunits accumulate and then reach very high concentrations at which they are able to influence $A C$. Since reassociation of $G_{\beta \gamma}$ subunits with $G_{\alpha}$ was not blocked in our present experimental conditions, such extreme concentrations of $G_{\beta y}$ as described in Nielsen et al. 1991 are highly improbable. Furthermore, specific blockade of the $G$ protein a subunit $G_{i}$ with pertussis toxin inhibited the entire [cAMP] decrease (Fig. 3.11), suggesting a principle role for $G_{i}$ rather than $G_{\beta \gamma}$ in transducing the 5$H T$ signal. Since $G_{s}$ and $G_{i}$ share the same pool of $G_{\beta \gamma}$ subunits, which are available to both of them without preference, $G_{\beta \gamma}$ cannot account for the $G_{i}$ dominance.

In conclusion, $G_{\beta \gamma}$ subunits are not responsible for the newly found signaling features upon 5$\mathrm{HT}_{1 \mathrm{~A}}-5-\mathrm{HT}_{7}$ coexpression. 


\subsection{Test setup}

As has been pointed out above, FRET imaging is a very comfortable way to measure changes in cellular cAMP concentrations in high temporal and spatial resolution. The principles of FRET measurements as well as the conversion of recorded $E f_{D A} / Y$ values to apparent [CAMP] values after cAMP calibration are to be found in chapter 2.1 and following. Optimal excitation and emission wavelengths were adjusted for respective filter sets in previous studies (Salonikidis et al. 2008). Hence, the different excitation lights and recorded emission lights do not unintentionally interfere with each other in terms of artefacts (see 2.1.5). All recorded FRET values are corrected for the donor bleedthrough, the inevitable donor emission fraction in the emission light of the acceptor filter set (see 2.1.3). Furthermore, special care was taken that the receptor labeling fluorophores do not interfere with each other or with the FRET fluorophores. Fig 2.5 shows the distinct emission spectra of the fluorescent dyes mCherry and quantum dots, which mark $5-\mathrm{HT}_{7}$ and $5-\mathrm{HT}_{1 \mathrm{~A}}$ receptors, respectively. This allows explicit differentiation and illustration of both receptors in different or within the same cells when using appropriate filter sets.

The $E f_{D A} / Y$ values were recorded during stimulation and inhibition of $5-\mathrm{HT}_{1 \mathrm{~A}}$ and $5-\mathrm{HT}_{7}$ expressing cells, while agonists and antagonists were applied into the cell solution bathing chamber. In this respect, it was difficult precisely to investigate differences in the stimulation response delays between the two receptors. Kinetic measurements were performed to find out if activation of the receptors might be in consecutive order. Figure 3.5 depicts the intervals between agonist application and detectable effect, depending on the receptor and the used biosensor (see 3.2.1). A illustrates the results with a bigger bathing chamber that held about $1500 \mu \mathrm{l}$. The delays between agonist application and receptor response ranged from 16 to 62 seconds in average and displayed no logical pattern of a faster or a slower receptor. B shows the results with a smaller optimized chamber with a volume of $500 \mu \mathrm{l}$ which was installed to increase the solution exchange speed. With the new chamber the delays averaged about $9 \mathrm{~s}$ for both receptors. A faster solution application approach might reveal a consecutive activation of the two receptors but was not feasible for the used setup as cells were prone to wash away from the cover slips. A difference in the stimulation reaction delays, if there is one, had to be smaller than 9 seconds. 


\subsection{Conclusion and outlook}

In FRET measurements coexpression of the two serotonin receptors $5-\mathrm{HT}_{1 \mathrm{~A}}$ and $5-\mathrm{HT}_{7}$ revealed a strong, complex interaction. The fundamental observation is that stimulation of 5 $\mathrm{HT}_{1 \mathrm{~A}}-5-\mathrm{HT}_{7}$ coexpressing cells with serotonin leads to a [CAMP] decrease as seen before in $5-\mathrm{HT}_{1 \mathrm{~A}}$ - only expressing cells. The $\mathrm{G}_{i}$ mediated adenyly cyclase inhibition appears clearly dominant towards $G_{s}$ mediated activation. With the help of receptor labeling and visual selection combined with supporting FACS measurements and functional analysis it can be excluded, that the observation is due to imbalanced expression of the two receptors. The blocking experiments showed that specific blockade of either receptor almost completely inhibits the 5-HT signal transduction in coexpressing cells, indicating the functional influence of both receptors. Blockade of the $G$ protein confirmed that the $A C$ inhibition is $G_{i}$ mediated. It was stunning that even application of the $5-\mathrm{HT}_{7}$ specific agonist AS19 elicits the same [CAMP] decrease that one would have expected upon $5-\mathrm{HT}_{1 \mathrm{~A}}$ activation. It became apparent that $5-\mathrm{HT}_{1 \mathrm{~A}}-5-\mathrm{HT}_{7}$ coexpression generates entirely novel signaling properties as compared to the single receptors.

In a vast number of cases coexpression has been reported to alter signaling features of several receptors (George 2000, Gomes et al. 2000, Rocheville 2000, Barki-Harrington 2003). Many times it has been shown that actual receptor oligomerization creates new receptor functionality with altered pharmacology or signaling properties (Lee 2004, Woehler and Ponimaskin 2009, Renner et al. 2012). Therefore, different models of crosstalk have been discussed that could account for the newly observed signal behavior in $5-\mathrm{HT}_{1 \mathrm{~A}}-5-\mathrm{HT}_{7}$ coexpressing cells.

Many serotonin receptors, including 5- $\mathrm{HT}_{1 \mathrm{~A}}$ and 5- $\mathrm{HT}_{7}$ (Kobe et al. 2008, Renner 2012) tend to oligomerize. That suggests the idea of a $5-\mathrm{HT}_{1 \mathrm{~A}}-5-\mathrm{HT}_{7}$ hetero - oligomer that can be (co-) transactivated and trans - inhibited as it has been reported in many similar cases (Rocheville 2000, Barki-Harrington 2003) (Fig. 4.1). However, the other possible explanations cannot be excluded according to the testing so far. Hence, altered $G$ protein coupling selectivities and agonist and antagonists affinities also have to be considered as feasible reasons for the new observations. Even though, these two possibilities require multiple, simultaneous changes and therefore seem less likely.

Further investigation is needed to clarify the exact nature of the $5-\mathrm{HT}_{1 \mathrm{~A}}-5-\mathrm{HT}_{7}$ interaction. It will have to be determined in detail under which circumstances the two receptors oligomerize. This can be done by receptor labeling and co-immunoprecipitation for example. 
For the physiological significance also the distribution of homo- and hetero - oligomers is interesting. In this respect, it is also important to examine in which neuronal microdomains 5$\mathrm{HT}_{1 \mathrm{~A}}$ and $5-\mathrm{HT}_{7}$ receptors coexist, both in concentrations that allow the described interaction to have an impact on physiological signaling processes. For this purpose FRET-based sensors can be applied that are anchored to specific membrane fractions and therefore measure the cAMP production in certain membrane associated compartments (Warrier et al. 2007). To find out if $5-\mathrm{HT}_{7}$ receptors also couple to $\mathrm{G}_{\mathrm{i}}$ upon coexpression it is conceivable to cut off the $\mathrm{G}$ protein binding sites and monitor if this modification changes the $5-\mathrm{HT}$ signal.

Furthermore, it is interesting if similar observations can be made with other serotonin receptor pairs.

However, even if the exact nature of $5-\mathrm{HT}_{1 \mathrm{~A}}-5-\mathrm{HT}_{7}$ interaction is yet to be understood, a strong functional interaction became evident and gives rise to further investigation of serotonin receptor crosstalk. Such types of receptor crosstalk are a universal feature of cellular signaling and fundamental to homeostasis (Millan 2008). 


\section{Summary}

Receptor crosstalk is a universal feature of signaling and interference happens on manifold pathway junctions. The physiological occurrence of the two serotonin receptor subtypes 5$\mathrm{HT}_{1 \mathrm{~A}}$ and $5-\mathrm{HT}_{7}$ in the same neuronal cells gave rise to the question of how their countercooperative impact merges on the mutual target adenylyl cyclase $(\mathrm{AC}) .5-\mathrm{HT}_{1 \mathrm{~A}}$ receptors are generally known to decrease the cellular cAMP concentration via $G_{i}$ mediated $A C$ inhibition. In contrast, $5-\mathrm{HT}_{7}$ receptors commonly increase [CAMP] via $A C$ stimulating $\mathrm{G}_{\mathrm{s}}$ proteins. Förster resonance energy transfer (FRET) measurements were performed in $5-\mathrm{HT}_{1 \mathrm{~A}}-5-\mathrm{HT}_{7}$ coexpressing cells to track cAMP development during stimulation in real time. Fluorescent receptor labeling and visual selection of the measuring cells, combined with supporting FACS data and functional analysis ensured equal receptor expression in analyzed cells. An additional consideration is that many serotonin receptors, including $5-\mathrm{HT}_{1 \mathrm{~A}}$ and $5-\mathrm{HT}_{7}$, tend to oligomerize. Oligomerization has been shown to alter signaling in a vast number of cases and might play a key role in the $5-\mathrm{HT}_{1 \mathrm{~A}}-5-\mathrm{HT}_{7}$ interaction. Coexpressing cells were stimulated with serotonin to examine what impact the common receptor expression had on [CAMP] and if one pathway appeared to be dominant. Subsequent specific inhibition of either receptor was supposed to review respective binding sites and further reveal the nature of 5$\mathrm{HT}_{1 \mathrm{~A}}-5-\mathrm{HT}_{7}$ interaction. Blocking on the $\mathrm{G}$ protein level allowed analysis of the last step of the 5-HT pathway before the preliminary end target, AC. The key results of the actual thesis are summarized below:

1. Upon 5-HT $1 \mathrm{~A}-5-\mathrm{HT}_{7}$ coexpression a strong functional interaction with dominance of the $G_{i}$ pathway became apparent. Coactivation of coexpressing cells leads to significant [CAMP] decrease.

2. Specific blockade of either receptor almost totally prevents 5-HT signaling in these cells.

3. Specific $5-\mathrm{HT}_{7}$ stimulation likewise induces a [cAMP] decrease.

Oligomerization of the two serotonin receptors might be a possible explanation for the newly observed signaling features. The available results cannot predict with certainty whether oligomerization occurs or not, but in any case a strong interaction became evident and gives rise to further investigation of serotonin receptor coexpression. 
Annex

\section{Annex}

\subsection{List of figures}

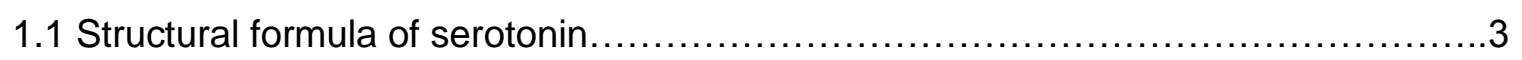

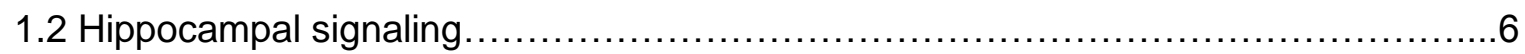

1.3 Principal serotonergic signaling cascades $\ldots \ldots \ldots \ldots \ldots \ldots \ldots \ldots \ldots \ldots \ldots \ldots \ldots \ldots \ldots$

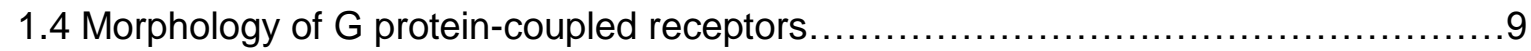

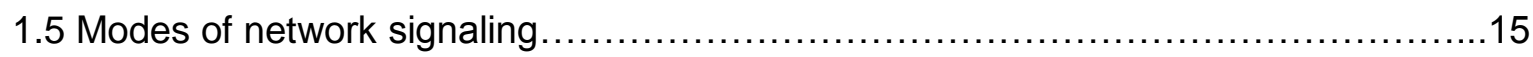

1.6 5- $-\mathrm{HT}_{1 \mathrm{~A}}-5-\mathrm{HT}_{7}$ coexpression in neurons and glia cells of the pre-Bötzinger complex..19

2.1 Förster resonance energy transfer of the CEPAC ${ }^{*}$ tandem construct..................21

2.2 Microscope and pathways of excitation and emission lights........................23

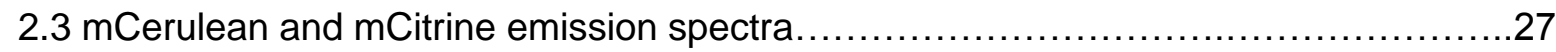

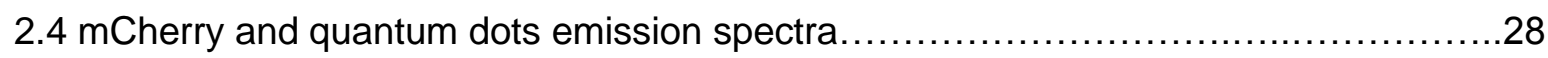

2.5 [CAMP] dependent donor and acceptor emission in CEPAC ${ }^{*} \ldots \ldots \ldots \ldots \ldots \ldots \ldots \ldots \ldots \ldots \ldots \ldots \ldots \ldots \ldots . .29$

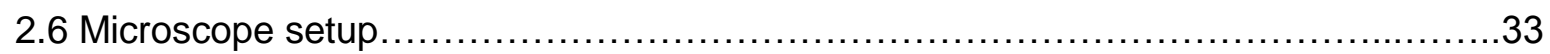

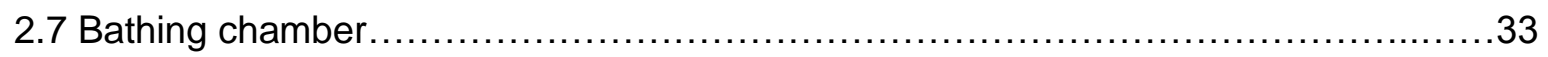

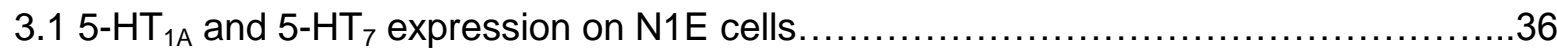

$3.25-\mathrm{HT}_{1 \mathrm{~A}}-5-\mathrm{HT}_{7}$ expression analysis on measuring cells............................

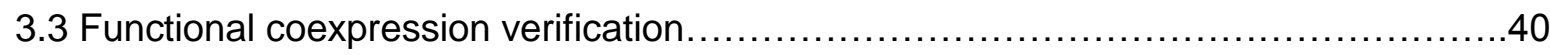

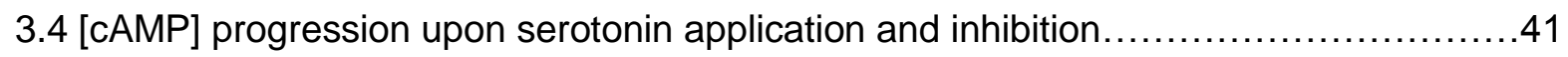

3.5 Kinetics of [cAMP] changes depending on the experimental setup and sensor..........43

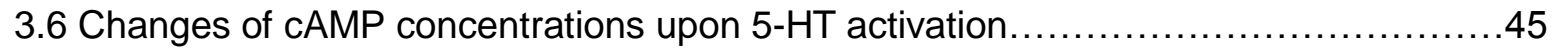

3.7 Specific blockade of previous 5-HT activation in single receptor expressing cells.......46

3.8 Control measurements: How receptor labeling affects FRET signaling ................47 
Annex

3.9 Specific inhibition of serotonin activation in $5-\mathrm{HT}_{1 \mathrm{~A}}-5-\mathrm{HT}_{7}$ coexpressing cells $\ldots . . . .49$

3.10 Specific $5-\mathrm{HT}_{7}$ stimulation and subsequent inhibition in coexpressing cells $\ldots \ldots \ldots . . .50$

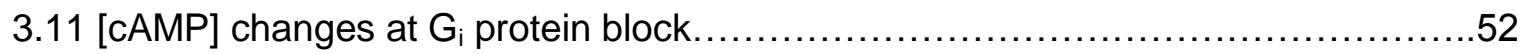

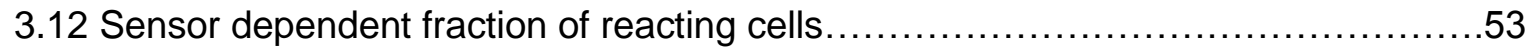

4.1 Signaling properties in $5-\mathrm{HT}_{1 \mathrm{~A}}-5-\mathrm{HT}_{7}$ coexpressing cells on the basis of a putative hetero-oligomer. .56

\subsection{Tables}

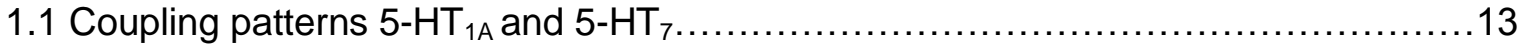

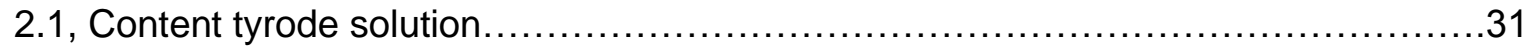




\section{References}

Adams SR, Harootunian AT, Buechler YJ, Taylor SS, Tsien RY (1991): Fluorescence ratio imaging of cyclic AMP in single cells. Nature 349, 694-7

Agarwal SR, MacDougall DA, Tyser R, Pugh SD, Calaghan SC, Harvey RD (2011): Effects of cholesterol depletion on compartmentalized cAMP responses in adult cardiac myocytes. $J$ Mol Cell Cardiol $\underline{50}, 500-509$

Amit A, Mester L, Klewe B, Furberg S (1978): The Chrystal Structure of Serotonin Hydrogen Oxalate. Acta Chem Scand $\underline{32}, 267-270$

Andrade R, Nicoll RA (1987): Pharmacologically distinct actions of serotonin on single pyramidal neurones of the rat hippocampus recorded in vitro. J Physiol $\underline{394}, 99$

Andressen KW, Norum JH, Levy FO, Krobert KA (2006): Activation of adenylyl cyclase by endogenous $\mathrm{G}(\mathrm{s})$-coupled receptors in human embryonic kidney 293 cells is attenuated by 5HT(7) receptor expression. Mol Pharmacol $\underline{69}$, 207-215

Attwood TK, Findlay JB (1994): Fingerprinting G-protein-coupled receptors. Protein Eng $\underline{7}$, 195-203

Azmitia EC, Gannon PJ (1986): The primate serotonergic system: a review of human and animal studies and a report on Macaca fascicularis. Adv Neurol $\underline{43}, 407-468$

Azmitia EC, Gannon PJ, Kheck NM, Whitaker-Azmitia PM (1996): Cellular localization of the $5-\mathrm{HT} 1 \mathrm{~A}$ receptor in primate brain neurons and glial cells. Neuropsychopharmacology $\underline{14}, 35-$ 46

Balcells-Olivero M, Cousins MS, Seiden LS (1998): Holtzman and Harlan Sprague-Dawley rats: differences in DRL 72-sec performance and 8-hydroxy-di-propylamino tetralin-induced hypothermia. J Pharmacol Exp Ther 286, 742

Banères JL, Parello J (2003): Structure-based analysis of GPCR function: evidence for a novel pentameric assembly between the dimeric leukotriene B4 receptor BLT1 and the Gprotein. J Mol Biol $\underline{329}$, 815-829

Bard JA, Zgombick J, Adham N, Vaysse P, Branchek TA, Weinshank RL (1993): Cloning of a novel human serotonin receptor (5-HT7) positively linked to adenylate cyclase. J Biol Chem $\underline{268}, 23422-23426$

Barki-Harrington L (2003): Dual Inhibition of beta-Adrenergic and Angiotensin II Receptors by a Single Antagonist: A Functional Role for Receptor-Receptor Interaction in Vivo. Circulation $\underline{108}, 1611-1618$

Béïque JC, Campbell B, Perring P, Hamblin MW, Walker P, Mladenovic L, Andrade R (2004): Serotonergic regulation of membrane potential in developing rat prefrontal cortex: coordinated expression of 5-hydroxytryptamine (5-HT) 1A, 5-HT2A, and 5-HT7 receptors. J Neurosci 24, 4807

Berg KA, Harvey JA, Spampinato U, Clarke WP (2005): Physiological relevance of constitutive activity of 5-HT2A and 5-HT2C receptors. Trends Pharmacol Sci $\underline{26}, 625-630$ 
Bickmeyer U, Heine M, Manzke T, Richter DW (2002): Differential modulation of Ih by serotonin receptor subtypes in CA1 neurones of mice. Eur J Neurosci 16, 209-218

Bos JL (2003): Epac: a new cAMP target and new avenues in cAMP research. Nat Rev Mol Cell Biol $\underline{4}(9), 733-8$

Bosker FJ Folgering JH, Gladkevich AV, Schmidt A, van der Hart MC, Sprouse J, den Boer JA, Westerink BH, Cremers TI (2009): Antagonism of 5-HT(1A) receptors uncovers an excitatory effect of SSRIs on 5-HT neuronal activity, an action probably mediated by 5-HT(7) receptors. J Neurochem $\underline{108}, 1126-1135$

Campbell S, Macqueen G (2004): The role of the hippocampus in the pathophysiology of major depression. J Psychiatry Neurosci 29, 417-426

Camps M, Carozzi A, Schnabel P, Scheer A, Parker PJ, Gierschik P (1992): Isozymeselective stimulation of phospholipase $\mathrm{C}$-beta 2 by $\mathrm{G}$ protein beta gamma-subunits. Nature $\underline{360}, 684-686$

Casas R, Tranel D: Higher Brain Functions; in: Neuroscience in Medicine. 3. Edition; edited by Conn PM a.o.; Springer Science+Business Media, Luxembourg 2008, 651-666

Cer RZ, Mudunuri U, Stephens R, Lebeda FJ (2009): IC50-to-Ki: a web-based tool for converting IC50 to Ki values for inhibitors of enzyme activity and ligand binding. Nucleic Acids Res $\underline{37}$, W441-W445

Chemel BR, Roth BL, Armbruster B, Watts VJ, Nichols DE (2006): WAY-100635 is a potent dopamine D4 receptor agonist. Psychopharmacology $\underline{188}$, 244-251

Cherezov V, Rosenbaum DM, Hanson MA, Rasmussen SG, Thian FS, Kobilka TS, Choi HJ, Kuhn P, Weis WI, Kobilka BK, Stevens RC (2007): High-resolution crystal structure of an engineered human beta2-adrenergic G protein-coupled receptor. Science $\underline{318}, 1258-1265$

Costagliola C, Parmeggiani F, Semeraro F, Sebastiani A (2008): Selective serotonin reuptake inhibitors: a review of its effects on intraocular pressure. Curr Neuropharmacol $\underline{6}$, 293-310

Dabiré H (1991): Central 5-hydroxytryptamine (5-HT) receptors in blood pressure regulation. Therapie $\underline{46}(6), 421-9$

De Rooij J, Zwartkruis FJ, Verheijen MH, Cool RH, Nijman SM, Wittinghofer A, Bos JL (1998): Epac is a Rap1 guanine-nucleotide-exchange factor directly activated by cyclic AMP. Nature $\underline{396}, 474-477$

De Rooij J, Rehmann H, van Triest M, Cool RH, Wittinghofer A, Bos JL (2000): Mechanism of Regulation of the Epac Family of cAMP-dependent RapGEFs. J Biol Chem $\underline{275}$, 2082920836

De Vivo M, Maayani S (1986): Characterization of the 5-hydroxytryptamine 1a receptormediated inhibition of forskolin-stimulated adenylate cyclase activity in guinea pig and rat hippocampal membranes. J Pharmacol Exp Ther 238, 248-253

Duncan MJ, Short J, Wheeler DL (1999): Comparison of the effects of aging on 5-HT7 and 5- 
HT1A receptors in discrete regions of the circadian timing system in hamsters. Brain Res $\underline{829}, 39-45$

Dutton AC, Massoura AN, Dover TJ, Andrews NA, Barnes NM (2008): Identification and functional significance of $\mathrm{N}$-glycosylation of the 5-ht5A receptor. Neurochem Int $\underline{52}, 419-425$

Eason M, Kurose H, Holt B, Raymond JR, Liggett S (1992): Simultaneous coupling of alpha 2 -adrenergic receptors to two G-proteins with opposing effects. Subtype-selective coupling of alpha $2 \mathrm{C} 10$, alpha $2 \mathrm{C} 4$, and alpha $2 \mathrm{C} 2$ adrenergic receptors to $\mathrm{Gi}$ and $\mathrm{Gs}$. J Biol Chem $\underline{267}$, 15795

Edagawa Y, Saito $H$, Abe K (1998): 5-HT1A receptor-mediated inhibition of long-term potentiation in rat visual cortex. Eur J Pharmacol $\underline{349}$, 221-224

Filipek S, Krzysko KA, Fotiadis D, Liang Y, Saperstein DA, Engel A, Palczewski K (2004): A concept for $G$ protein activation by $G$ protein-coupled receptor dimers: the transducin/rhodopsin interface. Photochem Photobiol Sci $\underline{3}$, 628-638

Fletcher A, Forster EA, Bill DJ, Brown G, Cliffe IA, Hartley JE, Jones DE, McLenachan A, Stanhope KJ, Critchley DJ (1996): Electrophysiological, biochemical, neurohormonal and behavioural studies with WAY-100635, a potent, selective and silent 5-HT1A receptor antagonist. Behav Brain Res $\underline{73}$, 337-353

Foster LJ, de Hoog CL, Mann M (2003): Unbiased quantitative proteomics of lipid rafts reveals high specificity for signaling factors. Proc Natl Acad Sci U S A $\underline{100}, 5813-5818$

George SR (2000): Oligomerization of micro- and delta -Opioid Receptors. GENERATION OF NOVEL FUNCTIONAL PROPERTIES. J Biol Chem $\underline{275}$, 26128-26135

Gershon MD (1999): Review article: roles played by 5-hydroxytryptamine in the physiology of the bowel. Aliment Pharmacol Ther 13 Suppl 2, 15-30

Gilbert F, Brazell C, Tricklebank MD, Stahl SM (1988): Activation of the 5-HT1A receptor subtype increases rat plasma ACTH concentration. Eur J Pharmacol 147, 431-439

Gloerich M, Bos JL (2010): Epac: defining a new mechanism for cAMP action. Annu Rev Pharmacol Toxicol $\underline{50}$, 355-375

Gomes I, Jordan BA, Gupta A, Trapaidze N, Nagy V, Devi LA (2000): Heterodimerization of mu and delta opioid receptors: A role in opiate synergy. J Neurosci $\underline{20}, \mathrm{RC} 110$

Griesbeck O, Baird GS, Campbell RE, Zacharias DA, Tsien RY (2001): Reducing the Environmental Sensitivity of Yellow Fluorescent Protein. MECHANISM AND APPLICATIONS. J Biol Chem 276, 29188-29194

Griffin MT, Figueroa KW, Liller S, Ehlert FJ (2007): Estimation of agonist activity at G proteincoupled receptors: analysis of M2 muscarinic receptor signaling through Gi/o,Gs, and G15. J Pharmacol Exp Ther $\underline{321}$, 1193-1207

Gu Z, Jiang Q, Yan Z (2007): RGS4 modulates serotonin signaling in prefrontal cortex and links to serotonin dysfunction in a rat model of schizophrenia. Mol Pharmacol $\underline{71}, 1030-1039$

Gulbins E, Lang F: Signaltransduktion; in: Physiologie des Menschen; pub. by Heckmann M 
a.o.; Springer-Verlag, Berlin 2011, 24-35

Gurevich VV, Gurevich EV (2008): GPCR monomers and oligomers: it takes all kinds. Trends Neurosci $\underline{31}, 74-81$

Guscott M Egan E, Cook GP, Stanton JA, Beer MS, Rosahl TW, Hartmann S, Kulagowski J, McAllister G, Fone KC, Hutson PH (2003): The hypothermic effect of 5-CT in mice is mediated through the 5-HT7 receptor. Neuropharmacology 44, 1031-1037

Hagan JJ, Price GW, Jeffrey P, Deeks NJ, Stean T, Piper D, Smith MI, Upton N, Medhurst AD (2000): Characterization of SB-269970-A, a selective 5-HT(7) receptor antagonist. $\mathrm{Br} J$ Pharmacol $\underline{130}, 539-548$

Hannon J, Hoyer, D (2008): Molecular biology of 5-HT receptors. Behav Brain Res $\underline{46}, 1-12$

Hedlund PB (2009): The 5-HT7 receptor and disorders of the nervous system: an overview. Psychopharmacology 206, 345-354

Heidmann DEA, Metcalf MA, Kohen R, Hamblin MW (1997): Four 5-Hydroxytryptamine7 (5HT7) Receptor Isoforms in Human and Rat Produced by Alternative Splicing: Species Differences Due to Altered Intron-Exon Organization. J Neurochem $\underline{68}, 1372-1381$

Hensler JG (2003): Regulation of 5-HT1A receptor function in brain following agonist or antidepressant administration. Life Sci $\underline{72}$, 1665-1682

Heusler P, Pauwels PJ, Wurch T, Newman-Tancredi A, Tytgat J, Colpaert FC, Cussac D (2005): Differential ion current activation by human $5-\mathrm{HT}(1 \mathrm{~A})$ receptors in Xenopus oocytes: evidence for agonist-directed trafficking of receptor signalling. Neuropharmacology $\underline{49}$, 963976

Hjorth S (1985): Hypothermia in the rat induced by the potent serotoninergic agent $8-\mathrm{OH}-$ DPAT. J Neural Transm $\underline{61}, 131-135$

Hoppe A, Christensen K, Swanson JA (2002): Fluorescence resonance energy transferbased stoichiometry in living cells. Biophys $\mathrm{J} \underline{83}, 3652-64$

Hoyer D Clarke DE, Fozard JR, Hartig PR, Martin GR, Mylecharane EJ, Saxena PR, Humphrey PP (1994): International Union of Pharmacology classification of receptors for 5hydroxytryptamine (Serotonin). Pharmacol Rev $\underline{46}, 157-203$

Iken K, Chheng S, Fargin A, Goulet AC, Kouassi E (1995): Serotonin Upregulates MitogenStimulated B Lymphocyte Proliferation through 5-HT1AReceptors. Cell Immunol 163, 1-9

Kamei K, Maeda N, Ogino R, Koyama M, Nakajima M, Tatsuoka T, Ohno T, Inoue T (2001): New 5-HT1A receptor agonists possessing 1,4-benzoxazepine scaffold exhibit highly potent anti-ischemic effects. Bioorg Med Chem Lett 11, 595-598

Kia HK, Brisorgueil MJ, Hamon M, Calas A, Vergé D (1996): Ultrastructural localization of 5hydroxytryptamine1A receptors in the rat brain. J Neurosci Res $\underline{46}, 697-708$

Kleine B, Rossmanith W: Hormone und Hormonsystem: Lehrbuch der Endokrinologie; 2 Edition; pub. by Bräuer H a.o.; Springer-Verlag, Berlin Heidelberg 2009, 181-184

Kobe F, Renner U, Woehler A, Wlodarczyk J, Papusheva E, Bao G, Zeug A, Richter 
DW, Neher E, Ponimaskin E (2008): Stimulation- and palmitoylation-dependent changes in oligomeric conformation of serotonin 5-HT1A receptors. Biochim Biophys Acta 1783, 15031516

Kobilka BK, Deupi X (2007): Conformational complexity of G-protein-coupled receptors. Trends Pharmacol Sci $\underline{28}, 397-406$

Koenig JI, Gudelsky GA, Meltzer HY (1987): Stimulation of corticosterone and betaendorphin secretion in the rat by selective $5-\mathrm{HT}$ receptor subtype activation. Eur J Pharmacol $\underline{137}, 1-8$

Krapivinsky G, Krapivinsky L, Wickman K, Clapham DE (1995): Glbetalgamma binds directly to the G protein-gated K+ channel, IKACh. J Biol Chem 270, 29059-29062

Kriegebaum C, Gutknecht L, Schmitt A, Lesch K, Reif A (2010 a): Serotonin Kompakt: Part 1. Fortschr Neurol Psychiatr $\underline{78}, 319-331$

Kriegebaum C, Gutknecht L, Schmitt A, Lesch KP, Reif A. (2010 b): Serotonin Kompakt: Part 2. [Behavioral genetics and psychopathology]. Fortschr Neurol Psychiatr $\underline{78}, 332-342$

Kvachnina E, Liu G, Dityatev A, Renner U, Dumuis A, Richter DW, Dityateva G, Schachner M, Voyno-Yasenetskaya TA, Ponimaskin (2005): EG 5-HT7 receptor is coupled to Glalpha subunits of heterotrimeric G12-protein to regulate gene transcription and neuronal morphology. J Neurosci 25, 7821-7830

Lambright DG, Noel JP, Hamm HE, Sigler PB (1994): Structural determinants for activation of the alpha-subunit of a heterotrimeric G protein. Nature $\underline{369}, 621-628$

Lang F, Lang P: Integrative Leistungen des Zentralnervensystems; in Basiswissen Physiologie, 2. Edition; pub. by Lang P a.o.; Springer-Verlag, Berlin 2007, 436-454

Laugwitz KL, Allgeier A, Offermanns S, Spicher K, Van Sande J, Dumont JE, Schultz G (1996): The human thyrotropin receptor: a heptahelical receptor capable of stimulating members of all four G protein families. Proc Natl Acad Sci U S A $\underline{93}, 116-20$

Lee SP (2004): Dopamine D1 and D2 Receptor Co-activation Generates a Novel Phospholipase C-mediated Calcium Signal. J Biol Chem 279, 35671-35678

Lin SL, Johnson-Farley NN, Lubinsky DR, Cowen DS (2003): Coupling of neuronal 5-HT7 receptors to activation of extracellular-regulated kinase through a protein kinase Aindependent pathway that can utilize Epac. J Neurochem 87, 1076-1085

Lingwood D, Simons K (2010): Lipid rafts as membrane-organizing principle. Science $\underline{327}$, 40-50

Logothetis DE, Kurachi Y, Galper J, Neer EJ. Clapham DE (1987): The beta gamma subunits of GTP-binding proteins activate the muscarinic K+ channel in heart. Nature $\underline{325}, 321-326$

Lovell PJ Bromidge SM, Dabbs S, Duckworth DM, Forbes IT, Jennings AJ, King FD, Middlemiss DN, Rahman SK, Saunders DV (2000): A Novel, Potent, and Selective 5-HT 7 Antagonist: (R)-3-(2-(2-(4-Methylpiperidin-1-yl)ethyl)pyrrolidine-1-sulfonyl)phenol (SB269970). J Med Chem 43, 342-345

Lovenberg TW, Baron BM, de Lecea L, Miller JD, Prosser RA, Rea MA, Foye PE, Racke 
M, Slone AL, Siegel BW (1993): A novel adenylyl cyclase-activating serotonin receptor (5HT7) implicated in the regulation of mammalian circadian rhythms. Neuron 11, 449-458

Maggio R, Novi F, Scarselli M, Corsini GU (2005): The impact of G-protein-coupled receptor hetero-oligomerization on function and pharmacology. FEBS J 272, 2939-2946

Magro F, Fraga S, Soares-da-Silva $P$ (2007): Short-term effect on intestinal epithelial $\mathrm{Na}+\mathrm{H}+$ exchanger by Gi [alpha] 1, 2-coupled 5-HT1A and Gq/11-coupled 5-HT2 receptors. Life Sci 81, 560-569

McGowan K, Kane A, Asarkof N, Wicks J, Guerina V, Kellum J, Baron S, Gintzler AR, Donowitz M (1983): Entamoeba histolytica causes intestinal secretion: role of serotonin. Science 221, 762-764

Miczek KA, Hussain S, Faccidomo S (1998): Alcohol-heightened aggression in mice: attenuation by $5-\mathrm{HT} 1 \mathrm{~A}$ receptor agonists. Psychopharmacology $\underline{139}, 160-168$

Millan MJ (2006): Multi-target strategies for the improved treatment of depressive states: conceptual foundations and neuronal substrates, drug discovery and therapeutic application. Pharmacol Ther $\underline{110}, 135-370$

Millan MJ, Marin P, Bockaert J, Mannoury la Cour C (2008): Signaling at G-protein-coupled serotonin receptors: recent advances and future research directions. Trends Pharmacol Sci $\underline{29}, 454-464$

Milligan G (1993): Mechanisms of multifunctional signalling by $G$ protein-linked receptors. Trends Pharmacol Sci 14, 239-244

Murray AJ, Tucker SJ, Shewan DA (2009): cAMP-dependent axon guidance is distinctly regulated by Epac and protein kinase A. J Neurosci 29, 15434-15444

Nakhai B, Nielsen DA, Linnoila M, Goldman D (1995): Two naturally occurring amino acid substitutions in the human 5-HT1A receptor: glycine 22 to serine 22 and isoleucine 28 to valine 28. Biochem Biophys Res Commun 210, 530-536

Nebigil CG, Garnovskaya MN, Casañas SJ, Mulheron JG, Parker EM, Gettys TW, Raymond JR (1995): Agonist-induced desensitization and phosphorylation of human 5-HT1A receptor expressed in Sf9 insect cells. Biochemistry $\underline{34}, 11954-11962$

Nelson DL (2004): 5-HT5 receptors. Curr Drug Targets CNS Neurol Disord Feb;ㅁ⑴:53-8

Neumaier J, Sexton T, Yracheta J, Diaz A, Brownfield M (2001): Localization of 5-HT7 receptors in rat brain by immunocytochemistry, in situ hybridization, and agonist stimulated cFos expression. J Chem Neuroanat $21,63-73$

Nielsen PE, Egholm M, Berg RH, Buchardt O (1991): Sequence-selective recognition of DNA by strand displacement with a thymine-substituted polyamide. Science $\underline{6}, 1497-500$

Ogren SO, Eriksson TM, Elvander-Tottie E, D'Addario C, Ekström JC, Svenningsson P, Meister B, Kehr J, Stiedl O (2008): The role of 5-HT1A receptors in learning and memory. Behav Brain Res $\underline{195}, 54-77$ 
Paila YD, Tiwari S, Sengupta D (2011): Chattopadhyay, Molecular modeling of the human serotonin1A receptor: role of membrane cholesterol in ligand binding of the receptor. Mol Biosyst $\underline{1}, 224-34$

Penington NJ, Kelly JS (1990): Serotonin receptor activation reduces calcium current in an acutely dissociated adult central neuron. Neuron $\underline{4}, 751-758$

Penington N, Kelly J, Fox (1993): A Whole-cell recordings of inwardly rectifying K+ currents activated by $5-\mathrm{HT} 1 \mathrm{~A}$ receptors on dorsal raphe neurones of the adult rat. J Physiol $\underline{469}, 387-$ 405

Peroutka S, Howell T (1994): The molecular evolution of G protein-coupled receptors: focus on 5-hydroxytryptamine receptors. Neuropharmacology $\underline{33}, 319-324$

Pindon A, van Hecke G, van Gompel P, Lesage AS, Leysen JE, Jurzak M (2002): Differences in signal transduction of two 5-HT4 receptor splice variants: compound specificity and dual coupling with Galphas- and Galphai/o-proteins. Mol Pharmacol 61, 85-96

Ponimaskin E, Heine M, Zeug A, Voyno-Yasenetskaya T, Salonikidis P (2007): Monitoring receptor-mediated changes of intracellular cAMP level by using ion channels and fluorescent proteins as biosensors. in: Serotonin Receptors in Neurobiology (Frontiers in Neuroscience). A. Chattopadhyay, editor. CRC Press, Boca Raton, FL, 2007, 19-40

Ponsioen B, Zhao J, Riedl J, Zwartkruis F, van der Krogt G, Zaccolo M, Moolenaar WH, Bos JL, Jalink K (2004): Detecting cAMP-induced Epac activation by fluorescence resonance energy transfer: Epac as a novel cAMP indicator. EMBO Rep $\underline{5}, 1176-1180$

Rapport MM (1949): Serum vasoconstrictor (serotonin) the presence of creatinine in the complex; a proposed structure of the vasoconstrictor principle. J Biol Chem 180, 961-969

Raymond JR, Mukhin YV, Gelasco A, Turner J, Collinsworth G, Gettys TW, Grewal JS, Garnovskaya MN (2001): Multiplicity of mechanisms of serotonin receptor signal transduction. Pharmacol Ther $\underline{\text { 92, }}$ 179-212

Renner $U$ Zeug A, Woehler A, Niebert M, Dityatev A, Dityateva G, Gorinski N, Guseva D, Abdel-Galil D, Fröhlich M (2012): Heterodimerization of serotonin receptors 5-HT1A and 5-HT7 differentially regulates receptor signalling and trafficking. J Cell Sci $\underline{125}, 2486-2499$

Resh MD (2006): Palmitoylation of ligands, receptors, and intracellular signaling molecules. Sci STKE 2006(359), re14

Rios C, Jordan B, Gomes I, Devi L (2001): G-protein-coupled receptor dimerization: modulation of receptor function. Pharmacol Ther $\underline{92}, 71-87$

Rizzo MA, Springer GH, Granada B, Piston DW (2004): An improved cyan fluorescent protein variant useful for FRET. Nat Biotechnol 22, 445-449

Rizzo MA, Springer G, Segawa K, Zipfel WR, Piston DW (2006): Optimization of Pairings and Detection Conditions for Measurement of FRET between Cyan and Yellow Fluorescent Proteins. Microsc Microanal 12, 238-54

Rocheville M (2000): Receptors for Dopamine and Somatostatin: Formation of HeteroOligomers with Enhanced Functional Activity. Science_288, 154-157 27 
Rosenbaum DM, Cherezov V, Hanson MA, Rasmussen SG, Thian FS, Kobilka TS, Choi HJ, Yao XJ, Weis WI, Stevens RC, Kobilka BK (2007): GPCR Engineering Yields HighResolution Structural Insights into 2-Adrenergic Receptor Function. Science 318, 1266-1273

Salonikidis PS: Elektrophysiologische Untersuchungen Zur Funktionellen Bedeutung Der N-Glykosilierung Des GABA-Transportproteins Besonders in Bezug Auf Die Kinetik Der Natrium-Transporter-Interaktion. Biophysikalisches Praktikum Anleitung, Universität Göttingen, Göttingen 2003

Salonikidis PS, Zeug A, Kobe F, Ponimaskin E, Richter DW (2008): Quantitative measurement of cAMP concentration using an exchange protein directly activated by a cAMP-based FRET-sensor. Biophys J 95, 5412-5423

Salonikidis PS, Niebert M, Ullrich T, Bao G, Zeug A, Richter DW (2011): An Ion-insensitive cAMP Biosensor for Long Term Quantitative Ratiometric Fluorescence Resonance Energy Transfer (FRET) Measurements under Variable Physiological Conditions. J Biol Chem 286, 23419-23431

Seifert R, Wenzel-Seifert K (2002): Constitutive activity of G-protein-coupled receptors: cause of disease and common property of wild-type receptors. Naunyn Schmiedebergs Arch Pharmacol $\underline{366}, 381-416$

Seletti B, Benkelfat C, Blier P, Annable L, Gilbert F, de Montigny C (1995): Serotonin1A receptor activation by flesinoxan in humans. Body temperature and neuroendocrine responses. Neuropsychopharmacology $\underline{13}$, 93-104

Serres F, Li Q, Garcia F, Raap DK, Battaglia G, Muma NA, Van de Kar LD (2000): Evidence that Gz-proteins couple to hypothalamic 5-HT1A receptors in vivo. J Neurosci 20, 3095-3103

Sharif NA, Drace CD, Williams GW Crider JY (2004): Cloned human 5-HT1A receptor pharmacology determined using agonist binding and measurement of cAMP accumulation. $J$ Pharm Pharmacol $\underline{56}, 1267-1274$

Simons K, Toomre D (2000): Lipid rafts and signal transduction. Nat Rev Mol Cell Biol 1, 3139

Singh JK, Yan Q, Dawson G, Banerjee P (1996): Cell-specific regulation of the stably expressed serotonin 5-HT1A receptor and altered ganglioside synthesis. Biochim Biophys Acta $\underline{1310}, 201-211$

Sprouse J, Reynolds L, Li X, Braselton J, Schmidt A (2004): 8-OH-DPAT as a 5-HT7 agonist: phase shifts of the circadian biological clock through increases in cAMP production. Neuropharmacology $\underline{46}, 52-62$

Steinberg SF, Brunton LL (2001): Compartmentation of G protein-coupled signaling pathways in cardiac myocytes Annu Rev Pharmacol Toxicol 41 , 751-773

Stephens L, Smrcka A Cooke FT, Jackson TR, Sternweis PC, Hawkins PT (1994): A novel phosphoinositide 3 kinase activity in myeloid-derived cells is activated by $\mathrm{G}$ protein beta gamma subunits. Cell $\underline{77}(1), 83-93$

Takeda J, Adachi K, Halprin KM, Itami S, Levine V, Woodyard C (1983): Forskolin activates adenylate cyclase activity and inhibits mitosis in in vitro in pig epidermis. J Invest Dermatol 81, 236-240 
Thomas DR, Melotto S, Massagrande M, Gribble AD, Jeffrey P, Stevens AJ, Deeks NJ, Eddershaw PJ, Fenwick SH, Riley G (2003): SB-656104-A, a novel selective 5-HT 7 receptor antagonist, modulates $\mathrm{REM}$ sleep in rats. Br J Pharmacol $\underline{139}, 705-714$

Tobin A (2008): G-protein-coupled receptor phosphorylation: where, when and by whom. $\mathrm{Br}$ J Pharmacol $\underline{153}$, S167-S176

Toth M (2003): 5-HT1A receptor knockout mouse as a genetic model of anxiety. Eur J Pharmacol $\underline{463}, 177-184$

Tsou A, Kosaka A, Bach C, Zuppan P, Yee C, Tom L, Alvarez R, Ramsey S, Bonhaus DW, Stefanich E (1994): Cloning and expression of a 5-hydroxytryptamine7 receptor positively coupled to adenylyl cyclase. J Neurochem $\underline{63}, 456-464$

Urban JD, Clarke WP, von Zastrow M, Nichols DE, Kobilka B, Weinstein H, Javitch JA, Roth BL, Christopoulos A, Sexton PM, Miller KJ (2007): Functional selectivity and classical concepts of quantitative pharmacology. J Pharmacol Exp Ther $\underline{320}, 1-13$

Van de Kar LD, Levy AD, Li Q, Brownfield MS (1998): A comparison of the oxytocin and vasopressin responses to the $5-\mathrm{HT} 1 \mathrm{~A}$ agonist and potential anxiolytic drug alnespirone (S20499). Pharmacol Biochem Behav $\underline{60}$, 677-683

Warrier S, Ramamurthy G, Eckert RL, Nikolaev VO, Lohse MJ, Harvey RD (2007): cAMP microdomains and L-type Ca2+ channel regulation in guinea-pig ventricular myocytes. J Physiol $\underline{580}, 765-776$

Woehler A, Ponimaskin EG (2009): G protein--mediated signaling: same receptor, multiple effectors. Curr Mol Pharmacol 2, 237-248

Woehler A, Wlodarczyk J, Neher E (2010): Signal/noise analysis of FRET-based sensors. Biophys J $\underline{99}$, 2344-2354

Yamada J, Sugimoto Y, Noma T, Yoshikawa T (1998): Effects of the non-selective 5-HT receptor agonist, 5-carboxamidotryptamine, on plasma glucose levels in rats. Eur $\mathrm{J}$ Pharmacol $\underline{359}, 81-86$ 
References

\section{Acknowledgements}

Special thanks to Dr. Kees Jalink (Department of Cellular Biophysics, The Netherlands Cancer Institute), who kindly provided cDNA encoding for the CFP-Epac(_DEP-CD)-YFP fusion construct and to Dr. Marcus Niebert for providing FACS analysis data and expert help and discussion. Also special thanks to Dr. Dr. Till Manzke and to Dr. Guobin Bao for expert help with Matlab protocols and discussions. Most of all, special thanks to Dr. Peter Salonikidis and Prof. Dr. Diethelm W. Richter for allocation of the work and constant support. This work was supported by the DFG through the Cluster of Excellence 171 and the DFG Research Center FZT103 "Nanoscale Microscopy and Molecular Physiology of the Brain" (CNMPB). 


\section{Lebenslauf}

Am 25. Oktober des Jahres 1985 bin ich als Sohn des Dipl.-Physikers Dr. Dieter Ullrich und der Lehrerin Gabriele Ullrich im Vinzenz-Krankenhaus in Braunschweig geboren worden. Ich wuchs mit zwei Geschwistern: Dr. Steffen Ullrich (40, Rechtsanwalt), Anneli Scholten (36, Aprobierte Pharmazeutin) auf. Ich besuchte ab dem Jahr 1992 die Grundschule Mascheroder Holz. Anschließend besuchte ich zwei Jahre lang die Orientierungsstufe Lindenberg und absolvierte schließlich mein Abitur im Jahr 2005 an dem Gymnasium Raabeschule im Heidberg mit der Note 1,0 mit den Leistungskursen Mathematik und Französisch. Im selben Jahr erfolgte der Beginn des Medizinstudiums an der Georg-AugustUniversität Göttingen. Im Jahr 2007 absolvierte ich den ersten Abschnitt der ärztlichen Prüfung mit der Note 2.0. Zwei Jahre später begann ich mit der Anfertigung meiner Promotionsarbeit mit dem Thema: Influence of GPCR co-expression in neuronal cells on the convergence of signaling pathways, gefördert durch die Exzellenzinitiative "Gö4med“. Begleitend arbeitete ich von 2008 bis 2010 als Hilfswissenschaftler in der Neuro- und Sinnesphysiologie und betreute studentische Tutorien. Im Oktober 2010 wechselte ich im Rahmen der Ausbildungskooperation zwischen der Georg-August-Universität Göttingen und den HELIOS Kliniken Berlin nach Berlin und absolvierte dort das letzte Studiensemester. Ab Februar 2011 begann mein praktisches Jahr, wovon ich zwei Tertiale an der Vanderbilt University school of medicine in Nashville, Tennessee, USA und ein Tertial am Emil von Behring Krankenhaus in Berlin verbracht habe. Im November 2012 erfolgte der zweite Abschnitt der ärztlichen Prüfung mit der Note 3.0. 